Prepared in cooperation with the North Carolina Department of Environment and Natural Resources, Division of Water Resources

\title{
Surface-Water Quality in Agricultural Watersheds of the North Carolina Coastal Plain Associated with Concentrated Animal Feeding Operations
}

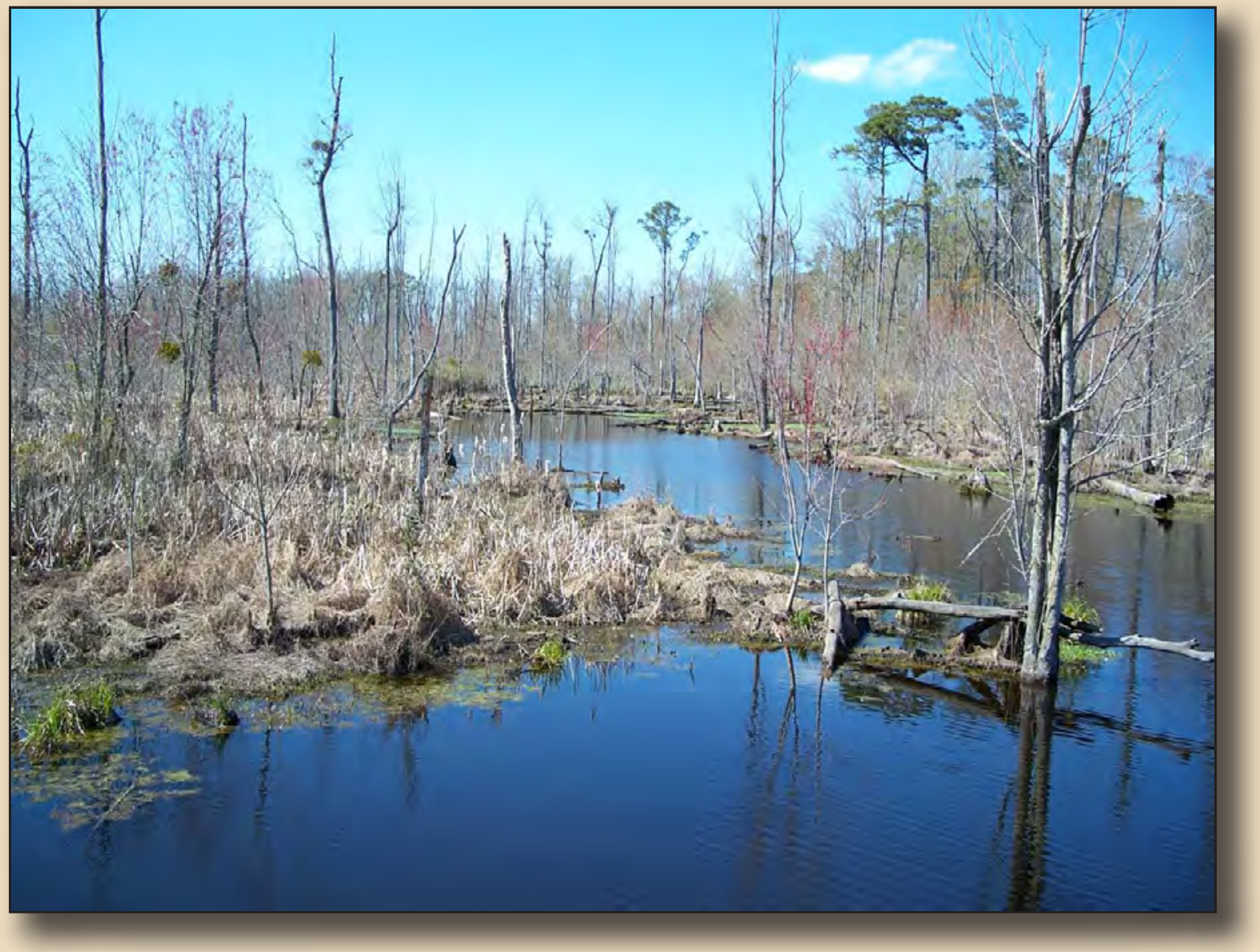

Scientific Investigations Report 2015-5080 
Front and back covers: Sandy Run tributary to Middle Swamp, Greene County, North Carolina. Photographs by Stephen Harden, U.S. Geological Survey. 


\section{Surface-Water Quality in Agricultural \\ Watersheds of the North Carolina Coastal \\ Plain Associated with Concentrated Animal Feeding Operations}

By Stephen L. Harden

Prepared in cooperation with the North Carolina Department of Environment and

Natural Resources, Division of Water Resources

Scientific Investigations Report 2015-5080 


\title{
U.S. Department of the Interior SALLY JEWELL, Secretary
}

\section{U.S. Geological Survey Suzette M. Kimball, Acting Director}

\author{
U.S. Geological Survey, Reston, Virginia: 2015
}

For more information on the USGS - the Federal source for science about the Earth, its natural and living resources, natural hazards, and the environment-visit http://www.usgs.gov or call 1-888-ASK-USGS.

For an overview of USGS information products, including maps, imagery, and publications, visit http://www.usgs.gov/pubprod/.

Any use of trade, firm, or product names is for descriptive purposes only and does not imply endorsement by the U.S. Government.

Although this information product, for the most part, is in the public domain, it also may contain copyrighted materials as noted in the text. Permission to reproduce copyrighted items must be secured from the copyright owner.

Suggested citation:

Harden, S.L., 2015, Surface-water quality in agricultural watersheds of the North Carolina Coastal Plain associated with concentrated animal feeding operations: U.S. Geological Survey Scientific Investigations Report 2015-5080, 55 p., 7 apps., http://dx.doi.org/10.3133/sir20155080.

ISSN 2328-0328 (online) 


\section{Acknowledgments}

The research described in this report was partially funded by the U.S. Environmental Protection Agency's 319 grant program that is administered by the North Carolina Department of Environment and Natural Resources, Division of Water Resources. The author thanks Keith Larick (former employee), Ted Bush, Rick Bolich, Michael Tutwiler, and Kim Nimmer of the North Carolina Department of Environment and Natural Resources for their help and support in this project. Appreciation is extended to the private landowners in eastern North Carolina who graciously allowed access to their property. This study would not have been possible without the help of U.S. Geological Survey personnel who assisted with sample collections and (or) data compilations, including Brian Pointer, Ryan Rasmussen, Sean Egen, Jessica Cain, Katharine Kolb, and Dominick Antolino. Finally, gratitude is extended to Thomas Cuffney, J.K. Böhlke, and Kristen McSwain, U.S. Geological Survey, for providing valuable technical discussions during the study, and to Judith Denver, Mary Giorgino, and Stephen Kalkhoff, U.S. Geological Survey, who provided many helpful review comments and suggestions on the report manuscript. 



\section{Contents}

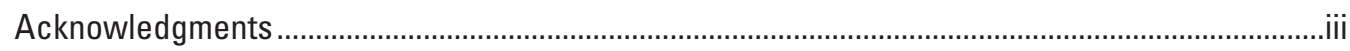

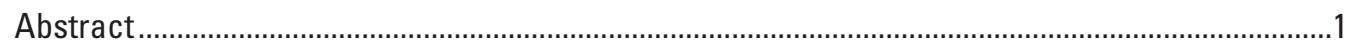

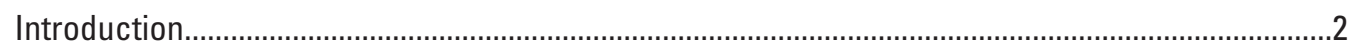

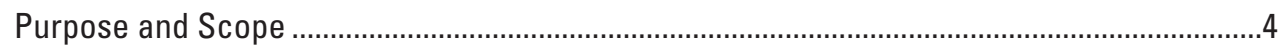

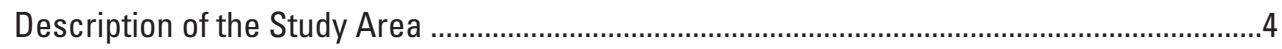

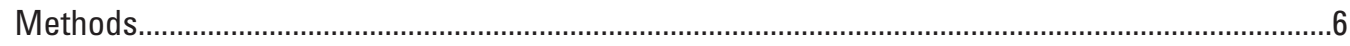

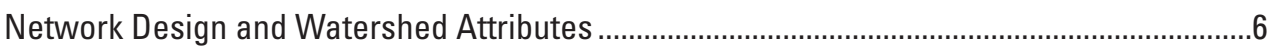

Land Cover and Hydrologic Soil Groups ...................................................................11

Wastewater Discharge Facilities and Non-Discharge Facilities....................................11

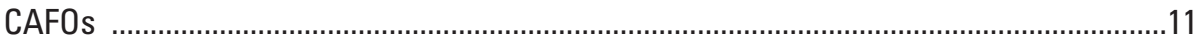

Swine CAFO Attributes .........................................................................................11

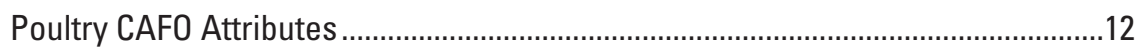

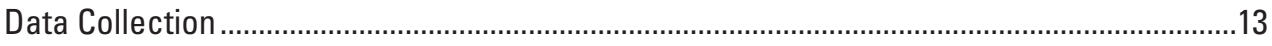

Precipitation and Streamflow..............................................................................

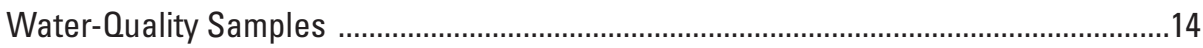

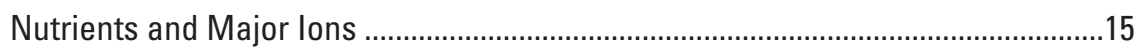

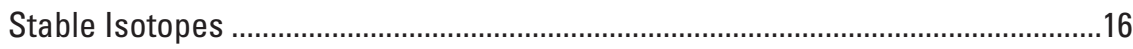

Quality Assurance ................................................................................................16

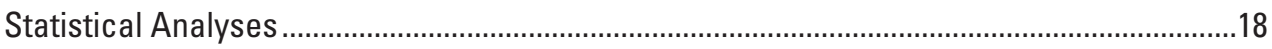

Characterization of Watershed Settings and Hydrologic Conditions ...........................................18

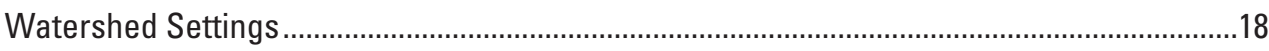

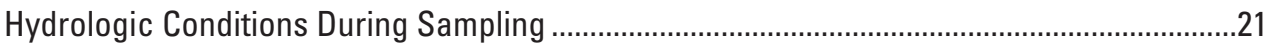

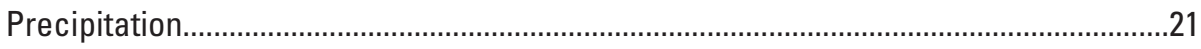

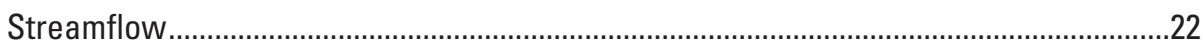

Water Stable Isotopes .....................................................................................................24

Comparison of Water-Quality Data by Sampling Period and Land-Use Type ..................................26

Seasonal and Flow-Related Water-Quality Differences .........................................................26

Water-Quality Differences Related to Watershed Land-Use Type............................................34

Multi-Analyte Approach for Differentiating Sites With Water-Quality Effects From CAFOs ..........38

Insights Based on Multi-Site Reconnaissance Sampling Within Selected Watersheds

During April 2013...................................................................................................38

Identification of Study Watersheds Having Measurable CAFO Effects on

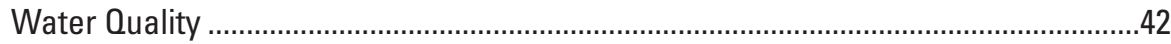

Watershed Attributes Associated With CAFO Water-Quality Effects...............................................47

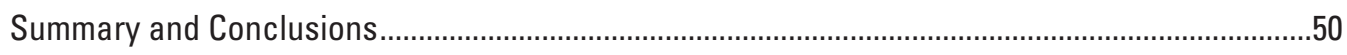

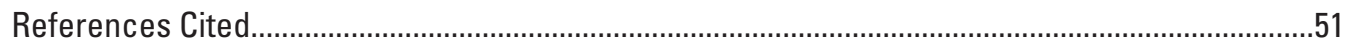




\section{Figures}

1. Map showing locations of permitted swine concentrated animal feeding operations in eastern North Carolina ...

2. Map showing locations of background, swine, and swine and poultry study sites, streamgage sites, and precipitation sites in the North Carolina Coastal

Plain study area .

3. Graph showing mean cumulative 7-day precipitation totals preceding each sample collection date based on raingage monitoring sites RG-01, RG-02, RG-03, and RG-04

4. Streamflow hydrographs at sites SG-01, SG-02, SG-03, SG-04, SG-05, and SG-06 showing dates water-quality samples were collected during the study and historical median daily mean streamflows.

5. Graph showing comparison of delta oxygen-18 to delta hydrogen-2 isotope values in precipitation samples collected from July 2012 to April 2013 at raingage sites RG-01 and RG-02 in the Coastal Plain study area.

6. Graph showing comparisons of delta oxygen-18 to delta hydrogen-2 isotope values of surface-water samples for June 2012, August 2012, October 2012,

December 2012, February 2013, and April 2013 sampling periods relative to the local meteoric water line

7. Distributions of temperature, specific conductance, dissolved oxygen, $\mathrm{pH}$, sodium, potassium, chloride, sulfate, ammonia plus organic nitrogen, ammonia, total organic nitrogen, nitrate plus nitrite, total nitrogen, orthophosphate, and total phosphorus for all study sites based on sampling period

8. Distributions of specific conductance, $\mathrm{pH}$, magnesium, sodium, potassium, chloride, sulfate, ammonia plus organic nitrogen, ammonia, nitrate plus nitrite, total nitrogen, and delta nitrogen-15 of nitrate plus nitrite for all sampling periods based on watershed land-use type

9. Common ranges in values of delta nitrogen- 15 and delta oxygen-18 of nitrate derived from various nitrogen sources (modified from Kendall and others, 2007)

10. Data comparisons of sodium plus potassium to nitrate plus nitrite, delta nitrogen-15 of nitrate plus nitrite to sodium plus potassium, and delta nitrogen-15 to delta oxygen-18 of nitrate plus nitrite for sites with and without CAFO manure influences and sites with unclear results based on the April 2013 dataset

11. Data comparisons of sodium plus potassium to nitrate plus nitrite, delta nitrogen-15 of nitrate plus nitrite to sodium plus potassium, and delta nitrogen-15 to delta oxygen-18 of nitrate plus nitrite for the background sites

12. Data comparisons of sodium plus potassium to nitrate plus nitrite, delta nitrogen-15 of nitrate plus nitrite to sodium plus potassium, and delta nitrogen-15 to delta oxygen-18 of nitrate plus nitrite at four representative sites with results similar to background conditions

13. Data comparisons of sodium plus potassium to nitrate plus nitrite, delta nitrogen-15 of nitrate plus nitrite to sodium plus potassium, and delta nitrogen- 15 to delta oxygen-18 of nitrate plus nitrite at four representative sites with results indicating manure effects

14. Classification tree model identifying the environmental predictor variables that best classified the 49 examined sites among the background, similar to background, and manure-influenced response categories 


\section{Tables}

1. Study network, including primary and associated secondary sites, monitored for water quality in the North Carolina Coastal Plain ......................................................7

2. Swine production type and average swine weight associated with concentrated animal feeding operations in the study area. . .12

3. Raingage monitoring sites in the North Carolina Coastal Plain study area used for collecting precipitation data.

4. Streamgage monitoring sites in the North Carolina Coastal Plain study area used for compiling streamflow data. 14

5. Nutrients and major ions measured in surface-water samples .....................................15

6. Statistical summary of relative percent differences in analyte concentrations for the environmental and replicate sample sets...............................................................17

7. Statistical summary of watershed attributes by land-use type ......................................19

8. Summary results of the ANOVA and Tukey multiple-comparison tests of watershed attributes by land-use type

9. Summary of the cumulative 7-day precipitation totals preceding each sample collection date based on raingage monitoring sites RG-01, RG-02, RG-03, and RG-04

10. Summary results of the two-way ANOVA tests on the ranked values of the water-quality properties and constituents based on sampling period and land-use type.

11. Statistical summary of water-quality properties and constituents by sampling period

12. Statistical summary of water-quality properties and constituents by land-use type. .35

13. Water-quality results for the April 2013 sample period used to examine waste-manure influences at the primary and secondary study sites

14. Statistical summary of selected water-quality constituents for the background sites, CAFO sites with results similar to background conditions, and CAFO sites with results reflecting manure influences. . .46

15. Classification tree model results for the $\mathbf{4 9}$ study sites. . .47

\section{Appendixes (available at http://pubs.usgs.gov/sir/2015/5080/)}

A1. Maps for the primary and secondary study sites PDF file

A2. Watershed land cover and hydrologic soil group data Excel files

A3. Data for non-discharge facilities, swine CAFOs, and poultry CAFOs Excel files

A4. Water-quality data for samples Excel files

A5. Evaluation of April 2013 water-quality dataset PDF file

A6. Identification of sites with manure influences Excel file

A7. Classification tree model data Excel file 


\section{Conversion Factors}

\begin{tabular}{lcl}
\hline \multicolumn{1}{c}{ Multiply } & By & \multicolumn{1}{c}{ To obtain } \\
\hline inch (in.) & Length & \\
foot (ft) & 25.4 & millimeter $(\mathrm{mm})$ \\
mile (mi) & 0.3048 & meter $(\mathrm{m})$ \\
\hline \multicolumn{1}{c}{ Area } & kilometer $(\mathrm{km})$ \\
\hline acre & 1.609 & square meter $\left(\mathrm{m}^{2}\right)$ \\
square mile $\left(\mathrm{mi}^{2}\right)$ & 4,047 & square kilometer $\left(\mathrm{km}^{2}\right)$ \\
\hline & 2.590 & \\
\hline gallon (gal) & Volume & liter $(\mathrm{L})$ \\
million gallons $(\mathrm{Mgal})$ & 3.785 & cubic meter $\left(\mathrm{m}^{3}\right)$ \\
\hline & 3,785 & \\
\hline cubic foot per second $\left(\mathrm{ft}^{3} / \mathrm{s}\right)$ & Flow rate & cubic meter per second $\left(\mathrm{m}^{3} / \mathrm{s}\right)$ \\
\hline & 0.02832 & \\
\hline ounce, avoirdupois $(\mathrm{oz})$ & Mass & gram $(\mathrm{g})$ \\
pound avoirdupois $(\mathrm{lb})$ & 28.35 & kilogram $(\mathrm{kg})$ \\
ton, short $(2,000 \mathrm{lb})$ & 0.4536 & megagram $(\mathrm{Mg})$ \\
\hline
\end{tabular}

Temperature in degrees Celsius $\left({ }^{\circ} \mathrm{C}\right)$ may be converted to degrees Fahrenheit $\left({ }^{\circ} \mathrm{F}\right)$ as ${ }^{\circ} \mathrm{F}=\left(1.8 \times{ }^{\circ} \mathrm{C}\right)+32$.

Specific conductance is given in microsiemens per centimeter at 25 degrees Celsius $\left(\mu \mathrm{S} / \mathrm{cm}\right.$ at $\left.25^{\circ} \mathrm{C}\right)$.

Concentrations of chemical constituents in water are given in either milligrams per liter (mg/L) or micrograms per liter $(\mu \mathrm{g} / \mathrm{L})$.

\section{Datum}

Horizontal coordinate information is referenced to the North American Datum of 1983 (NAD 83). 


\section{Abbreviations}

\begin{tabular}{ll} 
AFO & animal feeding operation \\
ANOVA & analysis of variance \\
BK sites & background watersheds with no active CAFOs \\
CAFO & concentrated animal feeding operation \\
DO & dissolved oxygen \\
DWR & North Carolina Division of Water Resources \\
EPA & U.S. Environmental Protection Agency \\
GIS & geographic information system \\
GMWL & global meteoric water line \\
HSG & hydrologic soil group \\
lidar & light detection and ranging \\
LMWL & local meteoric water line \\
N & nitrogen \\
NLCD & National Land Cover Database \\
NPDES & National Pollutant Discharge Elimination System \\
NPS & nonpoint source \\
NWIS & USGS National Water Information System \\
NWOL & USGS National Water Quality Laboratory \\
ortho-P & orthophosphate \\
P & phosphorus \\
PAN & plant available nitrogen \\
RL & reporting level \\
RPD & relative percent difference \\
RSIL & USGS Reston Stable Isotope Laboratory \\
SP sites & watersheds with at least one active swine CAFO and one active poultry CAFO \\
SSLW & steady state live weight \\
SW sites & watersheds with one or more active swine CAFOs but no poultry CAFOs \\
USGS & U.S. Geological Survey \\
\hline
\end{tabular}





\title{
Surface-Water Quality in Agricultural Watersheds of the North Carolina Coastal Plain Associated with Concentrated Animal Feeding Operations
}

\author{
By Stephen L. Harden
}

\section{Abstract}

The effects of concentrated animal feeding operations (CAFOs) on water quality were investigated at 54 agricultural stream sites throughout the North Carolina Coastal Plain during 2012 and 2013. Three general watershed land-use types were examined during the study, including 18 background watersheds with no active CAFOs (BK sites), 18 watersheds with one or more active swine CAFOs but no poultry CAFOs (SW sites), and 18 watersheds with at least one active swine $\mathrm{CAFO}$ and one active dry-litter poultry CAFO (SP sites). The watershed drainage areas for these 54 stream sites ranged from 1.2 to 17.5 square miles. Conventional fertilizers used for crop production are the primary source of nutrients at the BK sites. Animal-waste manures represent an additional source of nutrients at the SW and SP study sites.

Land cover, soil drainage, and CAFO attributes were compiled for each watershed. Water-quality field measurements were made and samples were collected at the 54 primary sites during 6 bimonthly sampling periods from June 2012 to April 2013. An additional 23 secondary sites were sampled once during April 2013 to provide supplemental data at stream locations directly adjacent or in close proximity to swine CAFOs and (or) background agricultural areas within 9 of the primary watersheds. The watershed drainage areas for the 23 secondary sites ranged from 0.2 to 8.9 square miles. Water temperature, specific conductance, dissolved-oxygen concentration, and $\mathrm{pH}$ were measured directly in the streams. Water samples were analyzed for major ions, nutrients, and stable isotopes, including delta hydrogen- $2\left(\delta^{2} \mathrm{H}\right)$ and delta oxygen-18 $\left(\delta^{18} \mathrm{O}\right)$ of water and delta nitrogen-15 $\left(\delta^{15} \mathrm{~N}\right)$ and $\delta^{18} \mathrm{O}$ of dissolved nitrate plus nitrite.

Most of the water-quality properties and constituents varied significantly among the six sampling periods, changing both seasonally and in response to hydrologic conditions. The differences noted among the sampling periods indicate that the interactions between seasonal climatic differences, streamflow conditions, and instream biotic and abiotic processes are complex and their integrated effects can have varying degrees of influence on individual nutrients.
Water-quality differences were noted for the SW and SP land-use groups relative to the BK group. Median values of specific conductance, several major ions (magnesium, sodium, potassium, and chloride), and nitrogen fractions (ammonia plus organic nitrogen, ammonia, nitrate plus nitrite, total nitrogen, and $\delta^{15} \mathrm{~N}$ of nitrate plus nitrite) were higher for the SW and SP groups compared to the BK group. No significant differences in water temperature, dissolved oxygen, calcium, total organic nitrogen, orthophosphate, total phosphorus, or $\delta^{18} \mathrm{O}$ of nitrate plus nitrite were noted among the land-use groups. When compared on the basis of land-use type, there was an overall measurable effect of CAFO waste manures on stream water quality for the SW and SP watershed groups.

Some individual sites within the $\mathrm{SW}$ and $\mathrm{SP}$ groups showed no measurable CAFO effects on water quality despite having CAFOs present upstream. An evaluation of sodium plus potassium concentrations coupled with $\delta^{15} \mathrm{~N}$ values of nitrate plus nitrite proved valuable for distinguishing which SW and SP sites had a water-quality signature indicative of CAFO waste manures. Sites with CAFO manure effects were characterized by higher sodium plus potassium concentrations (commonly between 11 and 33 milligrams per liter) and $\delta^{15} \mathrm{~N}$ values of nitrate plus nitrite (commonly between 11 and 26 parts per thousand) relative to sites reflecting background agricultural conditions, which commonly had sodium plus potassium concentrations between 6 and 14 milligrams per liter and $\delta^{15} \mathrm{~N}$ values of nitrate plus nitrite between 6 and 15 parts per thousand. On the basis of the results of this study, land applications of waste manure at swine CAFOs influenced ion and nutrient chemistry in many of the North Carolina Coastal Plain streams that were studied.

A classification tree model was developed to examine relations of watershed environmental attributes among the study sites with and without CAFO manure effects. Model results indicated that variations in swine barn density, percentage of wetlands, and total acres available for applying swinewaste manures had an important influence on those watersheds where CAFO effects on water quality were either evident or mitigated. Measurable effects of CAFO waste manures on stream water quality were most evident in those SW and SP watersheds having lower percentages of wetlands combined 
with higher swine barn densities and (or) higher total acres available for applying waste manure at the swine CAFOs. Stream water quality was similar to background agricultural conditions in SW and SP watersheds with lower swine barn densities coupled with higher percentages of wetlands or lower acres available for swine manure applications. The model provides a useful tool for exploring and identifying similar, unmonitored watersheds in the North Carolina Coastal Plain with potential CAFO manure influences on water quality that might warrant further examination.

\section{Introduction}

The U.S. Environmental Protection Agency's (EPA) National Water Quality Inventory Report to Congress (U.S. Environmental Protection Agency, 2010) lists pathogens, sediment, organic enrichment and oxygen depletion, and nutrients as several leading causes of impairment of rivers and streams in the United States. Agriculture, including crop and animal production, was cited as the most probable source of impairments in the assessed rivers and streams. Nonpointsource (NPS) pollution from agricultural activities is of particular concern in eastern North Carolina because nutrient over-enrichment in surface waters has contributed to waterquality problems in the Tar-Pamlico, Neuse, and Cape Fear River Basins, particularly in the estuaries (Spruill and others, 1998; Luettich and others, 2000; Burkholder and others, 2006). Excessive inputs of nitrogen $(\mathrm{N})$ and phosphorus $(\mathrm{P})$ to nutrient-sensitive waters can contribute to eutrophication, excess algal blooms, fish kills, and outbreaks of toxic dinoflagellates (Burkholder and others, 1995; Burkholder and Glasgow, 1997; Stow and others, 2001; Paerl and others, 2004). Animal feeding operations (AFOs) are recognized as important NPS contributors of N and P to streams in the North Carolina Coastal Plain physiographic province (Glasgow and Burkholder, 2000; Mallin and Cahoon, 2003; Burkholder and others, 2006; Rothenberger and others, 2009). Large amounts of land-applied animal manures in watersheds with high densities of AFOs can lead to nutrient surpluses that exceed the assimilative capacity of the watershed to absorb excess nutrients without having deleterious effects on water quality (Stone and others, 1998; Mallin and Cahoon, 2003; Hubbard and others, 2004; Sims and others, 2005; Copeland, 2010).

North Carolina is one of the Nation's leading animal producers, ranking second in the production of both swine and turkeys and fourth in the production of broiler chickens (North Carolina Department of Agriculture and Consumer Services, 2012). In North Carolina, AFOs are regulated and permitted as non-discharge facilities by the Animal Feeding Operations Program within the North Carolina Department of Environment and Natural Resources Division of Water Resources (DWR). As of January 2013, there were 2,356 individually permitted AFOs in North Carolina (North Carolina Division of Water Resources, 2013), with about
90 percent of the facilities consisting of swine AFOs (total of 2,132 ) and the remaining 10 percent consisting primarily of cattle (total of 199) and wet poultry (total of 21) AFOs. The majority of the swine AFOs $(2,006)$ are located in the Coastal Plain (fig. 1). Most poultry AFOs in North Carolina consist of dry-litter operations that are exempt from permitting by the State. The number of dry-litter poultry AFOs in the Coastal Plain is likely similar to the number of swine AFOs (Keith Larick, North Carolina Division of Water Resources, oral commun., June 2013).

It is of note that the terms AFO and concentrated animal feeding operation (CAFO) often are used interchangeably within the literature; however, there are technical distinctions between them as defined by the EPA (40 CFR $\S 122.23)$. The EPA generally defines AFOs as "operations where animals have been, are, or will be stabled or confined and fed or maintained for a total of 45 days or more in any 12-month period and where vegetation is not sustained in the confinement area during the normal growing season" (U.S. Environmental Protection Agency, 2012). An AFO may be further designated as a CAFO on the basis of the number of animals confined and specific criteria concerning the discharge of pollutants to adjacent surface waters, which if so designated makes the CAFO subject to National Pollutant Discharge Elimination Systems (NPDES) permitting requirements (40 CFR §122.23). In this report, swine and poultry feeding operations are collectively referred to as CAFOs even though they may not all technically meet the regulatory definitions.

At a typical swine CAFO, waste materials are flushed from the swine houses to one or more holding lagoons for temporary storage. Wastewater effluent from the lagoon(s) periodically is applied to nearby fields, commonly through surface spraying, in accordance with the permitted facility's Certified Animal Waste Management Plan such that the total $\mathrm{N}$ applied can be used during crop growth to avoid runoff or excessive leaching (Keith Larick, North Carolina Division of Water Resources, oral commun., June 2013); however, problems can result from adverse weather conditions or application rates that exceed crop uptake (Evans and others, 1984; Smith and Evans, 1998). At the poultry CAFOs, dry litter commonly is applied to cropland at the individual facilities if sufficient acreage is available, or the litter can be transported offsite and applied as a source of nutrients to other agricultural fields (Crouse and Shaffer, 2011).

Previous studies have examined the effects of swine and poultry CAFOs on groundwater and surface-water quality, especially regarding $\mathrm{N}$ and $\mathrm{P}$, in the North Carolina Coastal Plain. Huffman (2004) found that seepage from swine-waste lagoons built before 1993, without clay liners, increased shallow groundwater concentrations of mineral $\mathrm{N}$ (ammonia $\mathrm{N}$ plus nitrate $\mathrm{N})$ by 10 to 40 milligrams per liter $(\mathrm{mg} / \mathrm{L})$ as $\mathrm{N}$ at 11 sites and more than $40 \mathrm{mg} / \mathrm{L}$ as $\mathrm{N}$ at 16 sites. Various investigators have noted nitrate concentrations commonly between 10 and $30 \mathrm{mg} / \mathrm{L}$, and in some cases between 50 and $150 \mathrm{mg} / \mathrm{L}$, in groundwater collected beneath or adjacent to application fields receiving swine-lagoon effluent or 


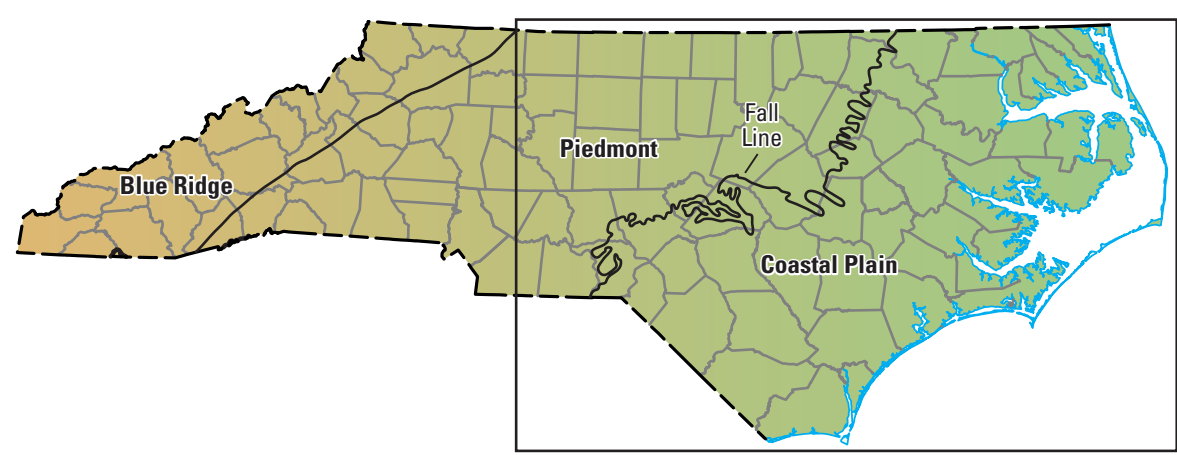

Location of the study area in North Carolina

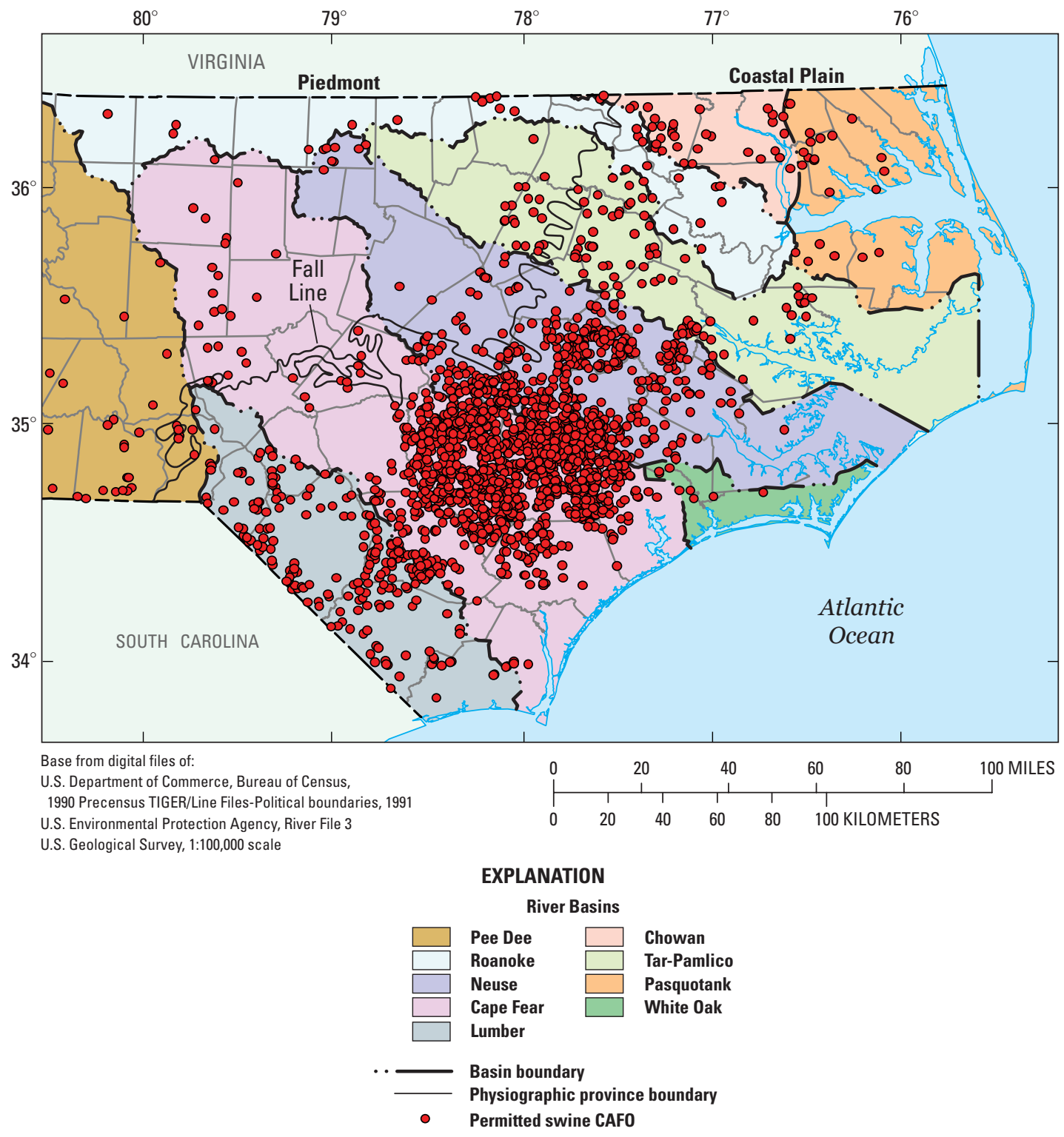

Figure 1. Locations of permitted swine concentrated animal feeding operations (CAFOs) in eastern North Carolina (swine CAFO locations obtained from North Carolina Division of Water Resources, 2013). 
Surface-Water Quality in Agricultural Watersheds of the North Carolina Coastal Plain Associated with CAFOs

poultry litter (Hunt and others, 1995; Stone and others, 1998; Karr and others, 2001; Spruill and others, 2002; Israel and others, 2005; Dukes and Evans, 2006; Harden and Spruill, 2008). In addition to nitrate, increased concentrations of calcium, magnesium, sodium, potassium, and chloride have been observed in groundwater beneath swine CAFO spray fields (Karr and others, 2001; Spruill and others, 2005). The transport of $\mathrm{P}$ from agricultural fields to surface water typically occurs through overland runoff; however, repeated applications of swine-waste manure to fields can lead to excess accumulations of $\mathrm{P}$ in soil and subsequent leaching to groundwater for possible offsite transport to receiving streams (Novak and others, 2000; Nelson and others, 2005).

Elevated nutrient concentrations also have been observed in streams receiving overland runoff, groundwater discharge, and subsurface tile drainage derived from CAFOs (Stone and others, 1995; Karr and others, 2001; Spruill and others, 2005; Dukes and Evans, 2006; Harden and Spruill, 2008). Stone and others (1995) noted that a stream with intensive swine and poultry operations had nutrient concentrations during both stormflow and baseflow conditions that were several times higher than those in an adjacent background stream with no animal operations. In the stream influenced by the CAFOs, mean concentrations were $5.6 \mathrm{mg} / \mathrm{L}$ as N for nitrate, $0.74 \mathrm{mg} / \mathrm{L}$ as $\mathrm{N}$ for ammonia, and $0.68 \mathrm{mg} / \mathrm{L}$ for orthophosphate during baseflow conditions, and mean concentrations were $5.4 \mathrm{mg} / \mathrm{L}$ as $\mathrm{N}$ for nitrate, $2.28 \mathrm{mg} / \mathrm{L}$ as $\mathrm{N}$ for ammonia, and $1.3 \mathrm{mg} / \mathrm{L}$ for orthophosphate during stormflow conditions. Surfacewater samples collected by Karr and others (2001) in a stream adjacent to two swine CAFOs had a median nitrate concentration of $6.7 \mathrm{mg} / \mathrm{L}$ as N. Harden and Spruill (2008) observed elevated levels of nitrate (median of 6.1 and range of 2.0 to $10.7 \mathrm{mg} / \mathrm{L}$ as $\mathrm{N}$ ), ammonia (median of 0.76 and range of 0.09 to $2.38 \mathrm{mg} / \mathrm{L}$ as $\mathrm{N}$ ), and dissolved $\mathrm{P}$ (median of 0.05 and range of 0.01 to $0.29 \mathrm{mg} / \mathrm{L}$ ) in 28 surface-water samples collected in 2006 during stormflow and baseflow conditions from a stream next to waste-manure application fields at a swine CAFO.

Elevated nitrate concentrations in this stream are considered to be strongly influenced by water discharged through a tile drain located in one of the adjacent spray fields (Spruill and others, 2005, Harden and Spruill, 2008). In 2006, water discharging from the tile drain to the stream had nitrate concentrations ranging from about 22 to $45 \mathrm{mg} / \mathrm{L}$ as N (Harden, 2008).

The practice of applying waste manure to fields at swine CAFOs is common in many watersheds throughout the Coastal Plain so there is substantial interest in understanding their influence on stream water quality. Many of the studies conducted to evaluate water-quality conditions related to CAFOs in the Coastal Plain have been limited in geographic extent, either focusing on individual farm sites or several streams within a particular watershed. The lack of stream water-quality data from a more representative number of watersheds makes it difficult for DWR to assess the extent to which effects of swine CAFOs on surface-water quality can be measured and how well existing CAFO regulations protect the waters of the State or to recommend effective changes to regulations or procedures. In 2011, DWR (formerly named the Division of Water Quality) and the U.S. Geological Survey (USGS) initiated a collaborative study to document whether swine CAFOs located in various Coastal Plain watersheds have a measurable effect on stream water quality. The study results presented in this report provide needed information from a large number of sites over a broader geographic area to better understand relations between swine CAFOs and stream water quality in eastern North Carolina.

\section{Purpose and Scope}

The primary purpose of this report is to summarize and synthesize chemical data collected from 54 agricultural watershed study sites throughout the North Carolina Coastal Plain to characterize water-quality conditions in streams receiving inputs from swine CAFOs compared to streams that receive inputs primarily from inorganic fertilizers. The scope of work included field measurements of water-quality properties and collection of surface-water samples for laboratory analysis of nutrients, major ions, and stable isotopes. Six rounds of bimonthly samples were collected from June 2012 to April 2013 at 54 primary watershed study sites. The last sampling round in April 2013 included collection and analysis of samples from 23 additional sites located within 9 of the 54 primary watersheds. Results were used to evaluate differences in stream water quality among watersheds with no CAFOs, watersheds with swine CAFOs, and watersheds with both swine and poultry CAFOs. Land cover, soil drainage class, and CAFO attributes (such as number of facilities, animal barns, swine animals, and total weight of swine) were used to examine potential relations between watershed environmental variables and water-quality conditions among the primary study sites. The main study objectives were to (1) assess water-quality differences among streams draining watersheds with and without land-applied CAFO waste manures, (2) examine the use of multiple chemical constituents for identifying effects of CAFOs on stream water quality, and (3) examine relations of environmental variables among watersheds with and without measurable CAFO manure effects. The study results are intended to assist water-resource managers and policy makers in their efforts to protect and improve stream water quality throughout North Carolina.

\section{Description of the Study Area}

The watershed sites examined in the Coastal Plain study area have drainage areas less than 20 square miles $\left(\mathrm{mi}^{2}\right)$ with land cover composed predominantly of cropland, forests, and wetlands. Most of the watersheds typically feature lowgradient blackwater streams and swamps with slow streamflow velocities. Varying degrees of submerged and floating aquatic vegetation and organic debris are present within and along the stream channels. These types of streams often have naturally low dissolved oxygen (DO) that can be depleted further as a result of nutrient and organic inputs from agricultural activities. 
When examining stream water quality at the agricultural watershed sites in this study, it is important to understand that different processes influence fate and transport of nutrient inputs from agricultural fields to receiving streams. Nutrients applied to agricultural fields that percolate through the soils to the underlying surficial aquifer can be transported with groundwater as it discharges to receiving streams. Hydrograph separations performed on streamflow data during previous investigations indicate that groundwater, thought to be derived mostly from shallow aquifer systems, commonly contributes about 50 to 60 percent of the average annual streamflow to streams in the North Carolina Coastal Plain (McMahon and Lloyd, 1995; Spruill and others, 2005; Harden and others, 2013). Therefore, groundwater is potentially a major contributor of water and agriculturally derived chemical constituents to the stream study sites, particularly when there is minimal overland runoff from precipitation.

Various environmental, hydrogeologic, and geochemical factors that influence nitrate transport along groundwater flow paths beneath agricultural fields to receiving streams in the North Carolina Coastal Plain are discussed by Spruill and others (2005) and Harden and Spruill (2008). These factors include depth to water and saturated thickness of the surficial aquifer (Tesoriero and others, 2000; Tesoriero and others, 2005), groundwater residence times (Puckett, 2004; Tesoriero and others, 2005; Seitzinger and others, 2006), availability of organic carbon to drive denitrification reactions (Korom, 1992), and presence of riparian buffers (Speiran and others, 1998; Spruill, 2000; Puckett, 2004; Seitzinger and others, 2006). In evaluating changes in nitrate concentrations along groundwater flow paths at five study sites in the Coastal Plain, Harden and Spruill (2008) determined that denitrification was the most influential factor responsible for observed decreases in groundwater nitrate along the flow paths.

Although some denitrification of groundwater nitrate occurred beneath the agricultural fields, nitrate reduction along the groundwater flow paths was most prevalent in the downgradient riparian buffer zone and hyporheic zone at the streams, where highly reduced conditions associated with organic-rich deposits enhanced the overall amount of denitrification.

The nitrate-reducing capacity of the buffer zone combined with that of the hyporheic zone can substantially lower the amount of groundwater nitrate discharged to streams in agricultural settings of the Coastal Plain (Spruill, 2000; Harden and Spruill, 2008). Depending on hydrogeologic and geochemical conditions, relatively young groundwater may move quickly along shallow flow paths beneath the riparian buffer and outpace the time needed for complete reduction of nitrate before discharging to a stream. Groundwater discharge along shallow flow paths may occur along seeps or channel walls that bypass the highly organic fluvial material in the hyporheic zone. If this water contains nitrate that has passed through the riparian buffer, the water can affect the nitrate concentration in the receiving stream.

In addition to groundwater transport, overland flow of water that occurs through field-drainage ditches is another important pathway that conveys nutrients from agricultural fields to receiving streams. Field-drainage ditches and subsurface tile drains commonly are used in the North Carolina Coastal Plain for improving drainage in agricultural fields with poorly drained soils (Evans and others, 1991; Gilliam and others, 1997). Water conveyed through the field ditches to the streams includes surface runoff from the fields, when rainfall amounts are greater than the infiltration capacity of soils, and subsurface inputs of shallow groundwater from beneath the fields. Lateral inflows of shallow groundwater through the banks and bottom of the ditches can occur during parts of the year when high water-table conditions are present beneath the fields. In fields with subsurface tile drains, shallow groundwater intercepted and collected by the tiles at the top of the water table is discharged through outlets directly to the ditches.

These drainage improvements lower the water table beneath agricultural fields, which increases the amount of land available for cultivation; however, the process of redirecting shallow groundwater beneath agricultural fields through tile drains and ditches can increase nutrient transport, particularly nitrate, in drainage water exiting the fields to receiving streams (David and others, 1997; Jaynes and others, 2001; Randall and Mulla, 2001; Harden and Spruill, 2004). As previously discussed, elevated nitrate concentrations in shallow groundwater beneath agricultural fields have commonly been observed in the Coastal Plain, especially at fields receiving land applications of animal-waste manures. A study by Harden and Spruill (2004) on the quality of drainage water from field ditches and tile drains in a North Carolina Coastal Plain watershed found that median concentrations of nitrate as $\mathrm{N}$ were significantly higher in water exiting field ditches $(8.2 \mathrm{mg} / \mathrm{L})$ and tile drains $(32.0 \mathrm{mg} / \mathrm{L})$ at fields receiving applications of swine-waste manures as compared to field ditches $(2.7 \mathrm{mg} / \mathrm{L})$ and tile drains $(6.8 \mathrm{mg} / \mathrm{L})$ at fields receiving applications of commercial fertilizers.

Because field ditches and tile drains are used to expedite the drawdown of the water table, they can allow groundwater with elevated nitrate levels in the upper part of the surficial aquifer beneath agricultural fields to bypass natural organicrich aquifer sediments in the riparian buffer and hyporheic zones that normally would reduce the amount of nitrate in groundwater discharging to the streams (Spruill, 2000; Harden and Spruill, 2008). Considering that most watersheds examined for this study have substantial riparian buffer zones and organic-rich floodplain deposits and, hence, a high degree of denitrification potential prior to groundwater discharge, it is probable that overland inputs of water through field drainage ditches contribute much of the nitrate delivered to the stream sites. Overland transport through the field ditches can occur anytime there is excessive runoff from storm events but is most common during sustained periods of high water-table conditions, which typically occur during the colder winter and early spring months, generally from December to April, when evapotranspiration is lowest. 


\section{Methods}

This section provides a discussion of the network design and watershed attributes compiled for the study sites, and the sampling and analytical methods used for generating the water-quality dataset. Statistical methods used during data analysis also are discussed.

\section{Network Design and Watershed Attributes}

An integrated approach was used for establishing the network of surface-water sampling sites for the study. Three general watershed land-use types, or groups, were included: watersheds with no active CAFOs (referred to as background (BK) sites); watersheds with one or more active swine CAFOs but no poultry CAFOs (referred to as SW sites); and watersheds with at least one active swine $\mathrm{CAFO}$ and one active poultry CAFO (referred to as SP sites). Although the initial study intent was to evaluate potential influences of swine CAFOs, it was difficult to find swine only watersheds across the study area that did not also contain poultry CAFOs. Therefore, the SP sites were included to provide data for additional watersheds containing swine CAFOs, as well as for examining potential differences between swine only sites and sites with both swine and poultry. Watersheds that contained only poultry CAFOs were not considered because it was outside the scope of work for this study.

The stream sites selected for study include an equal number (18) representing each of the BK, SW, and SP watershed land-use types (table 1; fig. 2) that also had similar distributions in watershed characteristics such as drainage areas and land cover. These 54 watershed sites are referred to as primary study sites because they were the primary focus of data-collection activities for the 6 bimonthly sampling periods from June 2012 to April 2013. The April 2013 sampling period included collection of surface-water samples from 23 additional sites, referred to as secondary sites, located within 9 of the primary watershed sites (table 1). One or more secondary sites were sampled upstream from the primary sites to provide additional water-quality data for stream sites located close or adjacent to swine CAFOs and (or) in subwatershed areas with no swine CAFOs. The study network spanned six river basins throughout the Coastal Plain in eastern North Carolina (table 1; fig. 2). Individual maps for the primary and secondary sites are provided in appendix A1 (figs. A1-1 through A1-54).
All study watersheds have than less than 10 percent developed (urban) lands, and none contain permitted NPDES wastewater-discharge facilities. Therefore, agricultural activities represent the most likely source of nutrients to the streams. The watersheds without CAFOs (BK sites) and with CAFOs (SW and SP sites) all contain agricultural lands where commercial fertilizers are used during the production of crops. The water-quality constituents analyzed in stream samples collected during the study include those essential primary nutrients $(\mathrm{N}, \mathrm{P}$, and potassium) and secondary nutrients (calcium, magnesium, and sulfur) found in commercial fertilizer materials commonly used in North Carolina for growing crops (Zublena and others, 1991; Tucker, 1999). These same essential plant nutrients, as well as sodium and chloride, are found in swine and poultry organic waste manures (Zublena and others, 1991, 1997a, 1997b; Barker and others, 1994; Osmond and Kang, 2008). Land applications of swine-waste manure and poultry litter represent an additional source of these constituents to agricultural fields in the SW and SP watersheds. Because watershed characteristics are similar among the three site groups, with the exception of the presence or absence of CAFOs, differences in stream concentrations of nutrients and (or) major ions observed at the SW and SP sites relative to the BK sites likely reflect inputs derived from swine and (or) poultry animal-waste manures.

Watershed boundaries and contributing drainage areas for the study sites were determined using the USGS StreamStats application developed for North Carolina (http://water.usgs.gov/osw/streamstats/north_carolina.html; Weaver and others, 2012). These features were calculated within StreamStats using a 30 -foot (ft) by 30 -ft lidar-derived digital elevation model (North Carolina Floodplain Mapping Program, 2012). Watershed drainage areas range from 1.2 to $17.5 \mathrm{mi}^{2}$ for the 54 primary sites and 0.2 to $8.9 \mathrm{mi}^{2}$ for the 23 secondary sites.

Data were compiled for selected watershed attributes to characterize environmental conditions at the study sites. Physical (land cover and soil drainage) and anthropogenic features (point-source dischargers, non-discharge land application sites, and CAFOs) were compiled using geographic information system (GIS) processes. The 54 primary sites were chosen to avoid or minimize potential influences of wastewater-discharge facilities, non-discharge facilities, and developed lands in order to facilitate water-quality interpretations between the watersheds with and without CAFOs. 
Table 1. Study network, including primary and associated secondary sites, monitored for water quality in the North Carolina Coastal Plain.

[ID, identification; HUC, hydrologic unit code; USGS, U.S. Geological Survey; NC, North Carolina; HWY, highway; SR, secondary road; mi², square miles]

\begin{tabular}{|c|c|c|c|c|c|c|c|}
\hline $\begin{array}{c}\text { Primary } \\
\text { study ID } \\
\text { (see fig. 2) }\end{array}$ & $\begin{array}{l}\text { Secondary study } \\
\text { ID associated } \\
\text { with primary sites } \\
\text { (see appendix A1) }\end{array}$ & River basin & $\begin{array}{l}\text { USGS station } \\
\text { number }\end{array}$ & USGS station name & $\begin{array}{l}\text { Decimal } \\
\text { latitude }\end{array}$ & $\begin{array}{l}\text { Decimal } \\
\text { longitude }\end{array}$ & $\begin{array}{l}\text { Drainage } \\
\text { area }\left(\mathrm{mi}^{2}\right)\end{array}$ \\
\hline BK-01 & & Roanoke & 0208102325 & Blue Hole Swamp at NC HWY 11/42 near Cahaba, NC & 36.01654 & -77.21197 & 14.9 \\
\hline BK-02 & & Roanoke & 02081065 & Smithwick Creek near Bear Grass, NC & 35.76589 & -77.05184 & 12.5 \\
\hline BK-03 & & Roanoke & 02081040 & Etheridge Swamp at SR 1326 near Oak City, NC & 35.98837 & -77.34820 & 3.9 \\
\hline BK-04 & & Roanoke & 0208103875 & Conoho Creek at SR 1336 near Oak City, NC & 36.01207 & -77.29780 & 10.0 \\
\hline BK-05 & & Roanoke & 0208105040 & Conoho Creek tributary at SR 1002 at Hassell, NC & 35.91971 & -77.27077 & 10.8 \\
\hline BK-06 & & Chowan & 0205309110 & Kirbys Creek tributary at SR 1356 near Pendleton, NC & 36.49604 & -77.17341 & 5.9 \\
\hline BK-07 & & Tar-Pamlico & 02083583 & Williamson Branch at SR 1128 near St. Lewis, NC & 35.79453 & -77.72893 & 4.5 \\
\hline BK-08 & & Tar-Pamlico & 02083889 & Tyson Creek at SR 1245 at Kings Crossroads, NC & 35.65818 & -77.55068 & 3.8 \\
\hline BK-09 & & Tar-Pamlico & 02084212 & Hunting Run near Pactolus, NC & 35.66947 & -77.26106 & 5.9 \\
\hline BK-10 & & Tar-Pamlico & 0208451810 & Beaverdam Swamp at SR 1520 near Alligoods, NC & 35.55525 & -76.92182 & 5.5 \\
\hline BK-11 & & Neuse & 02090770 & Whiteoak Swamp at SR 1514 near Holdens Crossroads, NC & 35.70709 & -77.75435 & 5.6 \\
\hline BK-12 & & Neuse & 0209096970 & Moccasin Run near Patetown, NC & 35.47927 & -77.90992 & 3.1 \\
\hline BK-13 & & Neuse & 02091623 & Langs Mill Run at SR 1242 near Fountain, NC & 35.64908 & -77.60427 & 5.9 \\
\hline BK-14 & & Neuse & 02091712 & Middle Swamp near Marlboro, NC & 35.56626 & -77.59853 & 14.7 \\
\hline BK-15 & & Cape Fear & 0210682145 & Big Creek at SR 1006 at Bethany Crossroads, NC & 35.05978 & -78.70102 & 6.1 \\
\hline BK-16 & & Cape Fear & 0210591785 & Sevenmile Swamp at US HWY 13 at Rosin Hill, NC & 35.20431 & -78.43143 & 9.2 \\
\hline BK-17 & & Cape Fear & 0210754615 & White Oak Branch at SR 1209 near Ivanhoe, NC & 34.61149 & -78.18248 & 3.9 \\
\hline BK-18 & & Lumber & 0213453011 & Horse Swamp at SR 2435 near Fairmont, NC & 34.52107 & -79.17844 & 5.4 \\
\hline SW-01 & & Roanoke & 02081016 & Steptoe Run near Scotland Neck, NC & 36.10934 & -77.37070 & 5.4 \\
\hline SW-02 & & Tar-Pamlico & 02083686 & Kitten Creek at SR 1251 near Sharp Point, NC & 35.70728 & -77.56920 & 9.0 \\
\hline SW-03 & & Tar-Pamlico & 0208368850 & Unnamed tributary to Otter Creek at SR 1615 near Sharp Point, NC & 35.73388 & -77.57359 & 4.8 \\
\hline \multirow[t]{3}{*}{ SW-04 } & & Neuse & 02089225 & Little Marsh Run at SR 1714 at Parkstown, NC & 35.37789 & -77.82240 & 1.2 \\
\hline & SW-04A & Neuse & 0208922490 & Little Marsh Run headwaters near Parkstown, NC & 35.38754 & -77.83183 & 0.4 \\
\hline & SW-04B & Neuse & 0208922495 & Little Marsh Run at St. Delight Ch. Road at Parkstown, NC & 35.38270 & -77.82576 & 1.0 \\
\hline \multirow[t]{4}{*}{ SW-05 } & & Neuse & 02089584 & Hornpipe Branch at SR 1130 near Deep Run, NC & 35.14308 & -77.66903 & 3.9 \\
\hline & SW-05A & Neuse & 0208958380 & Hornpipe Branch at SR 1137 near Deep Run, NC & 35.13115 & -77.66361 & 0.8 \\
\hline & SW-05B & Neuse & 0208958385 & Hornpipe Branch tributary at SR 1137 near Deep Run, NC & 35.13326 & -77.65996 & 0.5 \\
\hline & SW-05C & Neuse & 0208958390 & Hornpipe Branch tributary at SR 1130 near Deep Run, NC & 35.13682 & -77.66893 & 0.9 \\
\hline SW-06 & & Neuse & 02091960 & Creeping Swamp near Calico, $\mathrm{NC}$ & 35.42944 & -77.18974 & 11.2 \\
\hline SW-07 & & Neuse & 02090793 & Whiteoak Swamp tributary at SR 1514 at Drivers Store, NC & 35.70027 & -77.81418 & 1.3 \\
\hline \multirow[t]{5}{*}{ SW-08 } & & Neuse & 02091725 & Sandy Run at US HWY 13/258 at Lizzie, NC & 35.51625 & -77.61542 & 15.8 \\
\hline & SW-08A & Neuse & 0209172000 & Sandy Run at SR 1301 near Castoria, NC & 35.53175 & -77.65237 & 8.9 \\
\hline & SW-08B & Neuse & 0209172150 & Drainage ditch to Sandy Run at SR 1326 near Lizzie, NC & 35.51573 & -77.65001 & 1.2 \\
\hline & SW-08C & Neuse & 02091722 & Unnamed tributary to Sandy Run at SR 1301 near Lizzie, NC & 35.52024 & -77.64036 & 2.8 \\
\hline & SW-08D & Neuse & 02091724 & Unnamed tributary to Sandy Run at SR 1301 at Lizzie, NC & 35.51052 & -77.62631 & 1.2 \\
\hline
\end{tabular}


Table 1. Study network, including primary and associated secondary sites, monitored for water quality in the North Carolina Coastal Plain.-Continued

[ID, identification; HUC, hydrologic unit code; USGS, U.S. Geological Survey; NC, North Carolina; HWY, highway; SR, secondary road; mi² ${ }^{2}$ square miles]

\begin{tabular}{|c|c|c|c|c|c|c|c|}
\hline $\begin{array}{c}\text { Primary } \\
\text { study ID } \\
\text { (see fig. 2) }\end{array}$ & $\begin{array}{l}\text { Secondary study } \\
\text { ID associated } \\
\text { with primary sites } \\
\text { (see appendix A1) }\end{array}$ & River basin & $\begin{array}{l}\text { USGS station } \\
\text { number }\end{array}$ & USGS station name & $\begin{array}{l}\text { Decimal } \\
\text { latitude }\end{array}$ & $\begin{array}{l}\text { Decimal } \\
\text { longitude }\end{array}$ & $\begin{array}{l}\text { Drainage } \\
\text { area }\left(\mathrm{mi}^{2}\right)\end{array}$ \\
\hline SW-09 & & Cape Fear & 0210596803 & Hornet Swamp at SR 242 near Piney Green, NC & 35.11474 & -78.47670 & 4.0 \\
\hline SW-10 & & Cape Fear & 0210592050 & Ward Swamp at SR 1711 near Monks Crossroads, NC & 35.19976 & -78.30362 & 1.3 \\
\hline SW-11 & & Cape Fear & 0210770367 & Youngs Swamp at SR 1725 near Giddensville, NC & 35.16676 & -78.21747 & 2.1 \\
\hline SW-12 & & Cape Fear & 0210778920 & Big Branch at SR 1301 at Bowdens, NC & 35.06026 & -78.10009 & 3.2 \\
\hline \multirow[t]{3}{*}{ SW-13 } & & Cape Fear & 0210782015 & King Branch at SR 1305 at Friendship, NC & 35.06047 & -78.04184 & 1.9 \\
\hline & SW-13A & Cape Fear & 0210782010 & King Branch Headwaters near Friendship, NC & 35.06601 & -78.06513 & 0.8 \\
\hline & SW-13B & Cape Fear & 0210782013 & King Branch Headwaters at Friendship, NC & 35.06814 & -78.05202 & 1.2 \\
\hline SW-14 & & Lumber & 0213449620 & Rattlesnake Branch at SR 1516 at Lennons Crossroads, NC & 34.47430 & -78.85823 & 3.1 \\
\hline SW-15 & & Lumber & 0213453155 & Aaron Swamp at SR 2455 near McDonald, NC & 34.51163 & -79.20262 & 12.1 \\
\hline SW-16 & & Lumber & 0210899420 & Little Whites Creek at SR 1700 near Bluefield, NC & 34.54721 & -78.61481 & 3.6 \\
\hline SW-17 & & Lumber & 0210899878 & Horseshoe Swamp at SR 1713 near Lisbon, NC & 34.50059 & -78.53169 & 9.4 \\
\hline SW-18 & & Lumber & 0210910290 & Butler Branch at US HWY 701 near Wootens Crossroads, NC & 34.44726 & -78.72026 & 3.7 \\
\hline \multirow[t]{4}{*}{ SP-01 } & & Tar-Pamlico & 02084148 & Chicod Creek at SR 1565 near Grimesland, NC & 35.53304 & -77.18784 & 17.5 \\
\hline & SP-01A & Tar-Pamlico & 0208414580 & Chicod Creek tributary at SR 1782 at Boyds Crossroads, NC & 35.51606 & -77.19316 & 1.6 \\
\hline & SP-01B & Tar-Pamlico & 0208414590 & Chicod Creek tributary south of SR 1780 at Boyds Crossroads, NC & 35.52571 & -77.18306 & 2.0 \\
\hline & SP-01C & Tar-Pamlico & 0208414750 & Chicod Creek tributary north of SR 1780 at Boyds Crossroads, NC & 35.53302 & -77.18058 & 0.5 \\
\hline SP-02 & & Neuse & 0208813655 & White Oak Branch at SR 1144 near Strickland Crossroads, NC & 35.34614 & -78.37521 & 5.3 \\
\hline SP-03 & & Neuse & 02088285 & Thoroughfare Swamp near Dobbersville, NC & 35.23844 & -78.15107 & 14.3 \\
\hline \multirow[t]{3}{*}{ SP-04 } & & Neuse & 0208831520 & Falling Creek at SR 1102 near Dobbersville, NC & 35.27517 & -78.27242 & 3.7 \\
\hline & SP-04A & Neuse & 0208831504 & Falling Creek tributary at SR 1201 near Newton Grove, NC & 35.28633 & -78.29202 & 0.4 \\
\hline & $\mathrm{SP}-04 \mathrm{~B}$ & Neuse & 0208831510 & Falling Creek tributary at US HWY 13 near Newton Grove, NC & 35.27540 & -78.28327 & 1.5 \\
\hline \multirow[t]{3}{*}{ SP-05 } & & Neuse & 02089598 & Unnamed tributary to Southwest Creek at NC HWY 11 near Albrittons, NC & 35.18177 & -77.67071 & 1.4 \\
\hline & SP-05A & Neuse & 0208959780 & Southwest Creek tributary 2 at SR 1159 near Albrittons, NC & 35.18384 & -77.67951 & 0.5 \\
\hline & $\mathrm{SP}-05 \mathrm{~B}$ & Neuse & 0208959790 & Southwest Creek tributary at SR 1159 near Albrittons, NC & 35.17731 & -77.67791 & 0.4 \\
\hline SP-06 & & Cape Fear & 02105702 & Davis Creek at SR 1713 near Lisbon, NC & 34.54040 & -78.50994 & 2.3 \\
\hline SP-07 & & Cape Fear & 0210564590 & Hammonds Creek at SR 1709 near Elizabethtown, NC & 34.57002 & -78.56049 & 12.0 \\
\hline SP-08 & & Cape Fear & 0210687150 & Big Swamp at SR 1441 near Clement, NC & 35.08855 & -78.59019 & 3.6 \\
\hline SP-09 & & Cape Fear & 02107005 & Cypress Creek at SR 1503 near Ammon, NC & 34.78778 & -78.50896 & 7.6 \\
\hline & SP-09A & Cape Fear & 344734078312901 & Drainage ditch to Cypress Creek near Ammon, NC & 34.79279 & -78.52442 & 6.9 \\
\hline SP-10 & & Cape Fear & 02106011 & Unnamed tributary to Bearskin Swamp at SR 1240 at Concord, NC & 34.98793 & -78.43314 & 1.5 \\
\hline
\end{tabular}


Table 1. Study network, including primary and associated secondary sites, monitored for water quality in the North Carolina Coastal Plain.-Continued [ID, identification; HUC, hydrologic unit code; USGS, U.S. Geological Survey; NC, North Carolina; HWY, highway; SR, secondary road; mi², square miles]

\begin{tabular}{|c|c|c|c|c|c|c|c|}
\hline $\begin{array}{c}\text { Primary } \\
\text { study ID } \\
\text { (see fig. 2) }\end{array}$ & $\begin{array}{l}\text { Secondary study } \\
\text { ID associated } \\
\text { with primary sites } \\
\text { (see appendix A1) }\end{array}$ & River basin & $\begin{array}{c}\text { USGS station } \\
\text { number }\end{array}$ & USGS station name & $\begin{array}{l}\text { Decimal } \\
\text { latitude }\end{array}$ & $\begin{array}{l}\text { Decimal } \\
\text { longitude }\end{array}$ & $\begin{array}{l}\text { Drainage } \\
\text { area }\left(\mathrm{mi}^{2}\right)\end{array}$ \\
\hline \multirow[t]{5}{*}{ SP-11 } & & Cape Fear & 0210608620 & Six Runs Creek at SR 1742 near Giddensville, NC & 35.14064 & -78.25847 & 5.6 \\
\hline & SP-11A & Cape Fear & 0210608603 & Six Runs Creek at SR 1736 near Hobbton, NC & 35.16458 & -78.27822 & 0.7 \\
\hline & SP-11B & Cape Fear & 0210608607 & Six Runs Creek near Hobbton, NC & 35.15719 & -78.26996 & 1.2 \\
\hline & SP-11C & Cape Fear & 0210608610 & Unnamed tributary to Six Runs Creek near Giddensville, NC & 35.15619 & -78.26846 & 0.2 \\
\hline & SP-11D & Cape Fear & 0210608612 & Six Runs Creek near Giddensville, NC & 35.15041 & -78.26580 & 2.3 \\
\hline SP-12 & & Cape Fear & 0210778820 & Bear Swamp at SR 1301 at Bowdens, NC & 35.05736 & -78.13150 & 3.3 \\
\hline SP-13 & & Cape Fear & 0210782005 & Nahunga Creek at SR 1301 near Warsaw, NC & 35.02692 & -78.01086 & 8.2 \\
\hline SP-14 & & Cape Fear & 0210760950 & Poley Branch at SR 1534 at Outlaws Bridge, NC & 35.15245 & -77.85116 & 4.6 \\
\hline SP-15 & & Cape Fear & 0210760860 & Buck Marsh Branch at SR 1753 near Hines Crossroads, NC & 35.18423 & -77.87220 & 4.5 \\
\hline SP-16 & & Cape Fear & 0210798920 & Stephens Swamp at SR 1807 at Quinns Store, NC & 34.88644 & -77.72953 & 2.8 \\
\hline SP-17 & & Cape Fear & 0210858154 & Tenmile Swamp at SR 1207 near Cypress Creek, NC & 34.76237 & -77.66882 & 6.0 \\
\hline SP-18 & & Cape Fear & 0210850250 & Doctors Creek at SR 1129 near Shanghai, NC & 34.75101 & -78.16391 & 6.6 \\
\hline
\end{tabular}




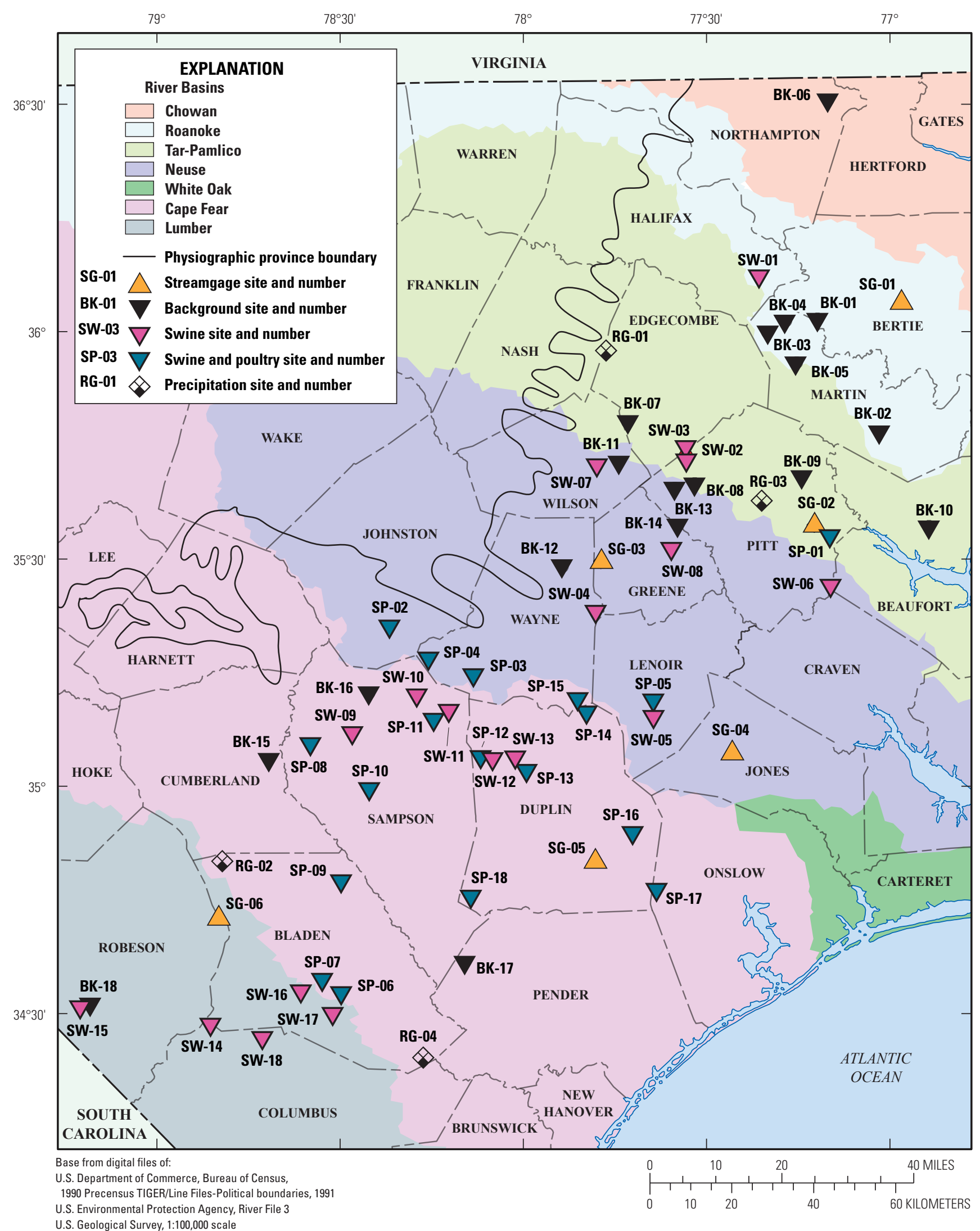

Figure 2. Locations of background, swine, and swine and poultry study sites, streamgage sites, and precipitation sites in the North Carolina Coastal Plain study area. 


\section{Land Cover and Hydrologic Soil Groups}

Watershed attributes for land cover and hydrologic soil groups (HSGs) were compiled using StreamStats. Land-cover information was derived from the 2006 National Land Cover Database (NLCD) (Fry and others, 2011), which includes 15 individual land-cover classes. These 15 individual land-cover classes were aggregated into 8 principal land-cover categories (developed, forested, shrub, crops, grassland, wetlands, barren, and water), which were summarized for each watershed (appendix A2-1).

The study sites contain HSGs with varying degrees of soil drainage capacity. Data used to characterize the distribution of HSGs within the study sites were obtained through the U.S. Department of Agriculture Soil Survey Geographic Database (Soil Survey Staff, Natural Resources Conservation Service, n.d.). The areal extent and relative percentage for the four major HSGs (A, B, C, and D) and three dually classified HSGs (A/D, B/D, and C/D) were determined within the watershed of each site (appendix A2-2). Soils in HSGs $\mathrm{A}$ and $\mathrm{B}$ have low to moderately low runoff potential when thoroughly wet. Soils in HSGs C and D have moderately high to high runoff potential when thoroughly wet. Thus, soils in HSGs A and B have a higher degree of drainage, or water infiltration, as compared to soils in HSGs C and D, which are more poorly drained.

The dual hydrologic groups represent wet soils that were naturally classified as very poorly drained (HSG D) because of the presence of a water table within $2 \mathrm{ft}$ of the land surface (U.S. Department of Agriculture, Natural Resources Conservation Service, 2009). If enhanced drainage measures, such as field ditches and subsurface tile drains, are used to maintain the seasonal high water table at least $2 \mathrm{ft}$ below the surface, then the soils are characterized by the first letter of the dual groups $(\mathrm{A} / \mathrm{D}, \mathrm{B} / \mathrm{D}$, or $\mathrm{C} / \mathrm{D})$ on the basis of their saturated hydraulic conductivity and depth of the water table when drained (U.S. Department of Agriculture, Natural Resources Conservation Service, 2009). For this study, the data compiled for dual HSGs A/D, B/D, and C/D are assumed to represent drained soil conditions and were summed with their respective major HSGs to yield HSG total A, HSG total B, and HSG total $\mathrm{C}$ (appendix A2-2).

\section{Wastewater Discharge Facilities and Non- Discharge Facilities}

Information on NPDES-permitted wastewater-discharge facilities and permitted non-discharge facilities was provided by DWR (Michael Tutwiler, North Carolina Division of Water Resources, written commun., April 2012). Wastewaterdischarge facilities that were considered included NPDESpermitted major municipal, minor municipal, major industrial/ commercial, and 100 percent domestic discharge facilities. Harden and others (2013) previously indicated that pointsource contributions of nutrients from wastewater-discharge facilities can have a significant influence on watershed nutrient yields in North Carolina. GIS analyses were used to map the locations of the discharge facilities in the Coastal Plain study area and to verify that none of the sites selected for study contained permitted dischargers.

GIS analyses also were performed to determine whether any permitted non-discharge facilities, which include wastewater irrigation, infiltration, or reclamation systems and land application of residual solids, were associated with the study sites. Only 2 of the 54 sites (SW-07 and SP-09) were found to have associated non-discharge facilities (appendix A3-1). Site SW-07 (appendix fig. A1-25) contains one residual solids landapplication field, and site SP-09 (appendix fig. A1-45) contains two residual solids land-application fields. Any potential effects of these residual solids application fields on the water-quality results obtained at sites SW-07 and SP-09 are considered minimal and are not discussed in this report.

\section{CAFOs}

Available information on permitted CAFOs, including swine, cattle, and wet-poultry operations, was provided by DWR (Keith Larick, North Carolina Division of Water Resources, written commun., April 2012). All permitted CAFOs located in the 54 primary watersheds were mapped using GIS processes. The subgroups of the BK, SW, and SP study sites were operationally defined on the basis of the absence or presence of permitted active swine CAFOs located within the watersheds. None of the sites contained permitted cattle or wet-poultry CAFOs. Dry-litter poultry CAFOs, which are not required to have permits, were present in the SP watersheds.

\section{Swine CAFO Attributes}

Attribute data for the swine CAFOs were based on available information for facilities having either an active or inactive State of North Carolina permit. Swine CAFOs with active permits represent those facilities with ongoing swine production and field applications of swine-waste manure from the storage lagoons. Swine CAFOs with inactive permits represent former swine production facilities that are no longer operational. The inactive facilities currently have no swine animals or ongoing disposal of waste manure in application fields; however, remnant infrastructure, including barns and (or) inactive lagoons, may still be located at some of these facilities. The GIS analyses indicated that 10 of the study sites have 1 or 2 inactive-swine permits (appendix A3-2). Other than the permit numbers and locations, no other data were available for these inactive CAFOs. The active CAFOs, with ongoing waste-manure applications, are considered to have a more pronounced influence than the inactive CAFOs on water-quality conditions at the sites. Given the lack of information available for the inactive CAFOs, data evaluations conducted during the study focused on the permitted active swine CAFOs; the permitted inactive swine CAFOs were not considered further. 


\section{Surface-Water Quality in Agricultural Watersheds of the North Carolina Coastal Plain Associated with CAFOs}

Several steps were taken in compiling attribute data for the active swine CAFOs. All active swine CAFOs within or along the boundaries of the $18 \mathrm{SW}$ and $18 \mathrm{SP}$ watershed sites were identified. Data provided by DWR for each active swine CAFO included information on the regulated swine activity, number of available acres for applying manure, amount of allowable plant available nitrogen (PAN), amount of generated PAN, and whether tile drains have been documented at the $\mathrm{CAFO}$ (appendix A3-3).

The regulated swine activity includes the type of swine production at the facility as well as the maximum annual average number of swine that can be produced. Seven types of swine production are associated with the CAFOs (Keith Larick, North Carolina Division of Water Resources, written commun., April 2012; table 2). Although multiple swine production activities are noted for some CAFOs, most produce only one type of swine. The average weight of swine produced and, consequently, the amount of waste manure generated by the swine population at a given CAFO depend on the type(s) of swine production at the facility. The maximum annual average number of swine (appendix A3-3) was multiplied by its respective average swine weight (table 2) to compute a total swine weight by production type. The number of swine and swine weights for all production types were summed to yield the total swine and total swine steady state live weight (SSLW) for each active CAFO.

The number of available acres listed for each active CAFO represents the total field acreage available at the facility for applying swine-waste manure (appendix A3-3). For a given facility, the amount of field acreage used for waste-manure applications during a given year may be lower than available. No information on the frequency and timing of applications or individual fields used was readily available for the CAFOs. The reported values for allowable PAN represent the maximum permitted amount of PAN that can be field applied annually at each CAFO. The reported values for generated PAN represent the calculated amount of PAN generated in waste manure that was field applied during 2012 at each CAFO (Keith Larick, North Carolina Division of Water Resources, written commun., July 2013). Ideally, the amount of generated PAN will be less than its allowable PAN on an annual basis such that the facility is not applying more PAN than allowed based on its permit.

Table 2. Swine production type and average swine weight associated with concentrated animal feeding operations in the study area.

\begin{tabular}{lc}
\hline Swine production type & $\begin{array}{c}\text { Average weight of swine by } \\
\text { production type (pounds) }\end{array}$ \\
\hline Gilts & 150 \\
Wean to feeder & 30 \\
Wean to finish & 115 \\
Feeder to finish & 135 \\
Farrow to wean & 433 \\
Farrow to feeder & 522 \\
Farrow to finish & 1,417 \\
\hline
\end{tabular}

Qualitative information on the documented presence of tile drains at the CAFOs (appendix A3-3) was based on those either reported by the facility operator or identified by DWR facility inspectors; however, no specific information was available on the number or locations of documented tile drains at the facilities. Although there are no documented tile drains for some CAFOs, this may not be completely accurate because there are likely tile drains located at some facilities, the existence of which is unknown, and these would have gone unreported. The tile drain data are provided for informational purposes and are not considered to accurately reflect the extent to which subsurface tile drains may or may not be associated with the swine CAFO waste-manure application fields in the SW and SP study sites.

Available orthoimagery in Google Earth (http://www.google.com/earth/; accessed May 2012) was visually examined to identify the total number of lagoons and swine barns associated with each active swine CAFO and, of these, how many of the lagoons and barns were located within the watershed boundaries (appendix A3-3). Some of the CAFOs were located along the watershed drainage boundaries and, under these circumstances, overland runoff and groundwater flow from those facilities may be transported toward receiving streams both within and outside of the study watersheds. In these cases, the permit attribute data associated with CAFOs situated along the drainage boundaries were adjusted with a correction factor to allocate that fraction of the data deemed to be associated within the study sites (appendix A3-3). Where needed, the correction factor used to adjust the attribute data generally was taken as the ratio of swine barns located within the watershed to the total swine barns associated with the CAFO.

Attributes for the individual swine CAFOs, which reflect adjustments applied for total swine, total swine weight, available acres, PAN allowed, and PAN generated, are provided in appendix A3-4. This information was used to compute the total number of active swine CAFOs, lagoons, swine barns, swine animals and weight, available acres, allowable PAN, and generated PAN within each of the SW and SP watershed sites (appendix A3-5). Total watershed densities per square mile of swine barns, swine animals, swine weight (in tons), and available acres were determined as additional parameters for each site for use in evaluating the water-quality data.

\section{Poultry CAFO Attributes}

Available orthoimagery in Google Earth (http://www.google.com/earth/; accessed May 2012) was visually examined to identify apparent dry-litter poultry CAFOs and their associated number of poultry barns located within each watershed of the study sites. The SP sites were the only study sites determined to have one or more apparent dry-litter poultry CAFOs; these sites also contain one or more permitted active swine CAFOs. The apparent dry-litter poultry CAFOs were visually distinguished from the documented swine CAFOs on the basis of the presence of waste-storage lagoons 
at the permitted swine facilities and the absence of any waste-storage lagoons at the dry-litter poultry facilities. For verification purposes, a list of the apparent dry-litter poultry CAFOs identified for the $18 \mathrm{SP}$ sites was provided to DWR for subsequent review by the North Carolina Department of Agriculture and Consumer Services, which indicated that the apparent dry-litter poultry CAFOs identified during this study were indeed active poultry facilities (Keith Larick, North Carolina Division of Water Resources, written commun., November 2012). No specific information on the operational characteristics (such as types and numbers of poultry raised, manure applications, or years of operation) for the dry-litter poultry CAFOs was publicly available for use in this study. Hereafter, the dry-litter poultry CAFOs at the study sites will be referred to as poultry CAFOs.

For this study, each cluster of poultry barns identified at the SP sites was considered to represent an individual poultry CAFO. Spatial coordinates and number of barns for the poultry CAFOs are provided in appendix A3-6. Each poultry $\mathrm{CAFO}$ was assigned a unique identifier, or field number, for use in this study. In some cases, adjacent poultry barn clusters may actually be part of the same operation. Similar to the process described previously for the swine CAFOs, in those cases where a poultry CAFO was located along the watershed drainage boundary, a prorated number of poultry barns was assigned to the CAFO to represent that fraction of the facility deemed to be within the watershed. The compiled information for the individual poultry CAFOs (appendix A3-6) was used to compute the total number of poultry CAFOs and poultry barns, as well as poultry barn density (barns per square mile), for each SP study site (appendix A3-7).

\section{Data Collection}

This section outlines procedures that were used to compile precipitation and streamflow monitoring data for examining hydrologic conditions in the study area. Sample collection procedures, laboratory analyses, and data qualityassurance practices are described for the water-quality data.

\section{Precipitation and Streamflow}

Precipitation data were obtained from four active USGS raingage monitoring stations (sites RG-01 through RG-04; table 3 ) in the Coastal Plain study area (fig. 2). Precipitation was measured at each site by using a tipping-bucket raingage that recorded precipitation at 15-minute intervals. Calibration checks were conducted semiannually on the raingages to ensure the accuracy of recorded data (U.S. Geological Survey, 2006). Precipitation data for sites RG-01, RG-02, RG-03, and RG-04 (table 3) are available from the USGS National Water Information System (NWIS) database (http://waterdata.usgs.gov/nc/nwis).

The precipitation data were used to better understand the extent to which each sampling date during the surface-water sampling periods was preceded by relatively wet or dry climatic conditions. For each raingage site, a cumulative total precipitation was computed for the 7-day period immediately preceding each date that samples were collected. Minimum, maximum, and mean values of the cumulative 7-day precipitation totals for the four raingage sites were determined for each sampling date for use in data analysis.

Ideally, instantaneous stream discharge would be measured to document streamflow conditions at the time water-quality samples are collected. However, the typical site conditions encountered during this study included low streamflow velocity coupled with varying degrees of submerged and floating aquatic vegetation within and along the stream channel. These conditions made it impractical to measure stream discharge during sample collections. Therefore, streamflow data were obtained from six active USGS streamgaging stations (sites SG-01 through SG-06; table 4) in the Coastal Plain study area (fig. 2) to describe regional hydrologic conditions during sampling periods. Streamflow data for the streamgage sites (table 4) are available from the USGS NWIS database (http://waterdata.usgs.gov/nc/nwis). 
Table 3. Raingage monitoring sites in the North Carolina Coastal Plain study area used for collecting precipitation data. [ID, identification; USGS, U.S. Geological Survey; NC, North Carolina]

\begin{tabular}{|c|c|c|c|c|c|}
\hline $\begin{array}{l}\text { Study site ID } \\
\text { (see fig. 2) }\end{array}$ & $\begin{array}{c}\text { USGS station } \\
\text { number }\end{array}$ & USGS station name & $\begin{array}{l}\text { Decimal } \\
\text { latitude }\end{array}$ & $\begin{array}{c}\text { Decimal } \\
\text { longitude }\end{array}$ & $\begin{array}{l}\text { Type of data } \\
\text { collected }\end{array}$ \\
\hline \multirow[t]{2}{*}{ RG-01 } & 355719077471345 & Raingage at Tar River at NC 97 at Rocky Mount, NC & 35.95536 & -77.78683 & $\begin{array}{l}\text { Precipitation water } \\
\text { quality }\end{array}$ \\
\hline & 02082585 & Tar River at NC 97 at Rocky Mount, NC & 35.95472 & -77.78722 & Continuous rainfall \\
\hline RG-02 & 345006078493145 & Raingage at Cape Fear River at Lock 3 near Tarheel, NC & 34.83503 & -78.82525 & $\begin{array}{l}\text { Precipitation water } \\
\text { quality }\end{array}$ \\
\hline RG-03 & 02084000 & Tar River at Greenville, NC & 35.61667 & -77.37278 & Continuous rainfall \\
\hline RG-04 & 02105769 & Cape Fear River at Lock 1 near Kelly, NC & 34.40444 & -78.29361 & Continuous rainfall \\
\hline
\end{tabular}

Table 4. Streamgage monitoring sites in the North Carolina Coastal Plain study area used for compiling streamflow data.

[ID, identification; USGS, U.S. Geological Survey; NC, North Carolina; $\mathrm{mi}^{2}$, square mile]

\begin{tabular}{lllccc}
\hline $\begin{array}{c}\text { Study site ID } \\
\text { (see fig. 2) }\end{array}$ & $\begin{array}{c}\text { USGS station } \\
\text { number }\end{array}$ & \multicolumn{1}{c}{ USGS station name } & $\begin{array}{c}\text { Decimal } \\
\text { latitude }\end{array}$ & $\begin{array}{c}\text { Decimal } \\
\text { longitude }\end{array}$ & $\begin{array}{c}\text { Drainage area } \\
\text { (mi }{ }^{2}\end{array}$ \\
\hline SG-01 & 0208111310 & Cashie River at SR 1257 near Windsor, NC & 36.04778 & -76.98417 & 108 \\
SG-02 & 02084160 & Chicod Creek at SR 1760 near Simpson, NC & 35.56167 & -77.23083 \\
SG-03 & 02091000 & Nahunta Swamp near Shine, NC & 35.48889 & -77.80611 & 45 \\
SG-04 & 02092500 & Trent River near Trenton, NC & 35.06417 & -77.46139 \\
SG-05 & 02108000 & Northeast Cape Fear River near Chinquapin, NC & 34.82889 & -77.83222 & 168 \\
SG-06 & 02134480 & Big Swamp near Tarheel, NC & 34.71028 & -78.83639 \\
\hline
\end{tabular}

\section{Water-Quality Samples}

Water-quality data compiled for the study include the analytical results for precipitation samples and surface-water samples. Precipitation samples were collected at raingage monitoring sites RG-01 and RG-02 from late July 2012 to early April 2013 for laboratory analyses. In this study, separate USGS station numbers are used for the precipitation water-quality data and the continuous rainfall data collected at monitoring stations RG-01 and RG-02 (table 3). The precipitation collectors were deployed for periods ranging from 2 days to 2 weeks to capture one or more rainfall events. The length of each deployment was based on the frequency and magnitude of rainfall events and the overall amount of rain that could be captured without overfilling the collection container. Clean sampling equipment was used for each deployment.

Samplers were not deployed during periods of extreme cold to avoid freezing, which could compromise the analytical results.

Surface-water samples were collected at the 54 primary and 23 secondary study sites (table 1) for laboratory analyses. Samples at the primary sites were collected during six rounds of bimonthly sampling, during June, August, October, and December 2012, and February and April 2013. Samples were collected at the secondary sites once during the April 2013 sampling round. The number of days needed to collect samples during each round ranged from 3 to 6 .
Water temperature, specific conductance, $\mathrm{pH}, \mathrm{DO}$, and barometric pressure were measured in the field during sample collections using instruments that were calibrated daily prior to sampling. Established, documented protocols were followed for collecting and processing samples for chemical analyses (U.S. Geological Survey, variously dated). Non-isokinetic methods were used for collecting samples because streamflow velocities generally were low. Samples were collected at the mid-depth of the water column at one or more points across the stream, depending on the stream width and type of road crossing (bridge or culverts). Subsamples collected from multiple points were composited into a single sample, representing the stream cross section.

Field equipment was cleaned between sampling sites (U.S. Geological Survey, variously dated). Samples were filtered and preserved in the field. A disposable 0.45-micron $(\mu \mathrm{m})$ pore size capsule filter was used to process samples for major ions and filtered nutrient fractions. Samples collected for the determination of nitrogen-15/nitrogen-14 $\left({ }^{15} \mathrm{~N} /{ }^{14} \mathrm{~N}\right)$ and oxygen-18/oxygen-16 $\left({ }^{18} \mathrm{O} /{ }^{16} \mathrm{O}\right)$ isotopic ratios of nitrate plus $(+)$ nitrite were filtered twice, first with a $0.45 \mu \mathrm{m}$ capsule filter followed by a $0.20 \mu \mathrm{m}$ disc filter, and subsequently frozen to prevent microbial degradation prior to laboratory analysis. 


\section{Nutrients and Major lons}

Surface-water samples were shipped to the USGS National Water Quality Laboratory (NWQL) in Lakewood, Colorado, for chemical analysis of nutrients and major ions. Methods and reporting levels (RL) for each measured analyte (table 5) remained consistent for all samples analyzed during the study. Unfiltered samples were analyzed for concentrations of total ammonia+organic $\mathrm{N}$ and total P. Filtered samples were analyzed for concentrations of dissolved ammonia, dissolved nitrate+nitrite, and dissolved orthophosphate (ortho-P).

Filtered samples also were analyzed to determine concentrations of dissolved calcium, chloride, magnesium, potassium, sodium, and sulfate.

The water-quality data for the surface-water samples are presented in appendix A4-1. One dataset includes waterquality results for all samples collected at the primary sites. The second dataset includes results for samples collected during the April 2013 sampling at the 9 primary sites and their 23 secondary sites. Analytical concentrations for the nitrogen species are reported in milligrams per liter as $\mathrm{N}$ and concentrations for ortho-P and total $\mathrm{P}$ are reported in milligrams per liter as P. The water-quality data also are available from the USGS NWIS database (http://waterdata.usgs.gov/nc/nwis).
Values for total organic $\mathrm{N}$ and total $\mathrm{N}$ (appendix A4-1) were computed from three directly measured nitrogen fractions (table 5). Total organic $\mathrm{N}$ was computed by subtracting dissolved ammonia from total ammonia+organic N. Total $\mathrm{N}$ was computed by summing total ammonia+organic $\mathrm{N}$ and dissolved nitrate+nitrite. If one of the underlying constituents used in computing total organic $\mathrm{N}$ or total $\mathrm{N}$ had a left-censored $(<)$ value, then the $<$ remark code was carried forward with the computed value. Although the $<$ remark codes were carried forward with the total organic $\mathrm{N}$ and total $\mathrm{N}$, they were ignored for the purpose of data evaluations in this study because the censoring levels associated with dissolved ammonia $(\mathrm{RL}=0.010 \mathrm{mg} / \mathrm{L})$ and dissolved nitrate+nitrite $(0.04 \mathrm{mg} / \mathrm{L})$ have minimal influence on the calculated values for total organic $\mathrm{N}$ and total $\mathrm{N}$, respectively. Thus, examinations of the total organic $\mathrm{N}$ and total $\mathrm{N}$ data were based on the concentrations as reported in appendix A4-1 without regard to any $<$ remark codes associated with the computed values. It is of note that, by default, total organic $\mathrm{N}$ and total $\mathrm{N}$ concentrations retrieved from the NWIS database retain the $<$ remark code if one of the underlying constituents is left-censored. The handling of censored data is left to the discretion of data users.

Table 5. Nutrients and major ions measured in surface-water samples.

[N, nitrogen; P, phosphorus; mg/L, milligram per liter; EPA, U.S. Environmental Protection Agency; APHA, American Public Health Association]

\begin{tabular}{lcl}
\hline \multicolumn{1}{c}{ Analyte } & $\begin{array}{c}\text { Reporting } \\
\text { level, in mg/L }\end{array}$ & \multicolumn{1}{c}{ Analytical reference } \\
\hline Nutrients & \\
\hline Ammonia as N, dissolved & 0.010 & Fishman (1993) \\
Ammonia + organic nitrogen as N, total & 0.07 & Patton and Truitt (2000) \\
Nitrate + nitrite as N, dissolved & 0.04 & Patton and Kryskalla (2011) \\
Orthophosphate as P, dissolved & 0.004 & Fishman (1993) \\
Phosphorus as P, total & 0.004 & USEPA (1993) \\
\hline & Major ions & \\
\hline Calcium, dissolved & 0.022 & Fishman (1993) \\
Chloride, dissolved & 0.06 & Fishman and Friedman (1989) \\
Magnesium, dissolved & 0.011 & Fishman (1993) \\
Potassium, dissolved & 0.03 & APHA (1998) \\
Sodium, dissolved & 0.06 & Fishman (1993) \\
Sulfate, dissolved & 0.09 & Fishman and Friedman (1989) \\
\hline
\end{tabular}




\section{Stable Isotopes}

Surface-water and precipitation samples were shipped to the USGS Reston Stable Isotope Laboratory (RSIL) in Reston, Virginia, for analysis of stable isotopes by using a continuous flow isotope-ratio mass spectrometer. Surface-water samples were analyzed for stable isotope ratios of water (hydrogen-2/ hydrogen- $1\left[{ }^{2} \mathrm{H} /{ }^{1} \mathrm{H}\right]$ and ${ }^{18} \mathrm{O} /{ }^{16} \mathrm{O}$ ) and (or) stable isotope ratios of dissolved nitrate+nitrite $\left({ }^{15} \mathrm{~N} /{ }^{14} \mathrm{~N}\right.$ and $\left.{ }^{18} \mathrm{O} /{ }^{16} \mathrm{O}\right)$. Precipitation samples were analyzed for stable isotope ratios of water $\left({ }^{2} \mathrm{H} /{ }^{1} \mathrm{H}\right.$ and $\left.{ }^{18} \mathrm{O} /{ }^{16} \mathrm{O}\right)$.

Stable isotope ratios are reported using the delta $(\delta)$ notation in units of parts per thousand (denoted as per mil or \%o) relative to a standard of known composition according to the following equation:

$$
\delta(\% \mathrm{o})=\left(\mathrm{R}_{\mathrm{samp}} / \mathrm{R}_{\text {stand }}-1\right) * 1,000
$$

where $\mathrm{R}_{\text {samp }}$ and $\mathrm{R}_{\text {stand }}$ are the ratios of the heavy to light isotope $\left({ }^{2} \mathrm{H} /{ }^{1} \mathrm{H},{ }^{18} \mathrm{O} /{ }^{16} \mathrm{O}\right.$, or $\left.{ }^{15} \mathrm{~N} /{ }^{14} \mathrm{~N}\right)$ in the sample and standard, respectively.

Stable isotopes of water $\left(\delta^{2} \mathrm{H}\right.$ and $\left.\delta^{18} \mathrm{O}\right)$ were analyzed in surface-water samples collected at the primary sites (appendix A4-1) and in precipitation samples collected at sites RG-01 and RG-02 (appendix A4-2) following methods outlined in Révész and Coplen (2008a, b). Results for $\delta^{2} \mathrm{H}$ and $\delta^{18} \mathrm{O}$ of water are reported with a 2-sigma $(\sigma)$ uncertainty of $\pm 2 \%$ and $\pm 0.2 \%$, respectively. Analysis of stable isotopes of dissolved nitrate + nitrite $\left(\delta^{15} \mathrm{~N}\right.$ and $\left.\delta^{18} \mathrm{O}\right)$ in surface-water samples was based on the microbial denitrifier method (Sigman and others, 2001; Casciotti and others, 2002; Coplen and others, 2012). Measurements of $\delta^{15} \mathrm{~N}$ and $\delta^{18} \mathrm{O}$ of dissolved nitrate + nitrite generally were performed on samples for the primary and secondary study sites with nitrate+nitrite concentrations greater than or equal to the RL of $0.04 \mathrm{mg} / \mathrm{L}$ (appendix A4-1). The $\delta^{15} \mathrm{~N}$ and $\delta^{18} \mathrm{O}$ results are reported with 2- $\sigma$ uncertainties of $\pm 0.5 \%$ and $\pm 1.0 \%$, respectively, when analyzed samples had nitrate+nitrite concentrations greater than or equal to $0.06 \mathrm{mg} / \mathrm{L}$ as $\mathrm{N}$; the uncertainties are doubled for samples with nitrate+nitrite concentrations less than $0.06 \mathrm{mg} / \mathrm{L}$ as $\mathrm{N}$.

An important issue to note regarding $\delta^{18} \mathrm{O}$ analyses with the denitrifier method is that the $\delta^{18} \mathrm{O}$ values generated for combined nitrate+ + nitrite may be underestimated if samples contain appreciable amounts of nitrite, yet the nitrite contributions to the $\delta^{18} \mathrm{O}$ results are not taken into account (Casciotti and others, 2007). When available, measured concentrations of nitrite are used to make applicable corrections to the $\delta^{18} \mathrm{O}$ results (Casciotti and McIlvin, 2007; Casciotti and others, 2007). In this study, however, samples were analyzed for combined nitrate+nitrite concentrations rather than individual concentrations of nitrate and nitrite. Therefore, the $\delta^{18} \mathrm{O}$ values of nitrate+nitrite reported in appendix A4-1 may underestimate actual values. The extent to which the results may have been biased by unaccounted-for nitrite in the samples is unknown.
Although nitrite concentrations were not determined for samples collected during this study, nitrite typically constitutes a relatively small amount ( $<10$ percent) of the overall nitrate+nitrite observed in streams in the North Carolina Coastal Plain. With nitrite likely representing less than 10 percent of the measured nitrate+nitrite in the study samples, the potential low bias associated with the $\delta^{18} \mathrm{O}$ values determined for nitrate+nitrite should be relatively muted. The presence of unrecognized nitrite in samples with the lowest concentrations of nitrate+nitrite (near the analytical RL of $0.04 \mathrm{mg} / \mathrm{L}$ ) would likely have the most pronounced bias on the nitrate+nitrite $\delta^{18} \mathrm{O}$ results. Therefore, evaluations of the stable isotope data $\left(\delta^{15} \mathrm{~N}\right.$ and $\left.\delta^{18} \mathrm{O}\right)$ for dissolved nitrate+nitrite in this study were focused on those samples having nitrate+nitrite concentrations greater than or equal to $0.100 \mathrm{mg} / \mathrm{L}$ in an effort to reduce the potential uncertainties associated with the nitrate+nitrite $\delta^{18} \mathrm{O}$ results.

\section{Quality Assurance}

Quality-control samples, including field blanks and replicate samples, were collected to document potential bias and variability in data that may result during the collection, processing, shipping, and handling of environmental samples (U.S. Geological Survey, variously dated). Field blanks were collected using inorganic-free water processed in the field with the same equipment used for the environmental samples. Field blanks help to identify contamination resulting from improperly cleaned equipment, field sampling activities and exposure, and laboratory practices. Overall, the results of the field blanks did not indicate any systematic or substantial quality-assurance issues with the environmental data. Replicate samples were collected to help document the variability in data results associated with sample collection, processing, and laboratory analysis. No quality-assurance problems were identified for the environmental dataset based on the replicate samples.

A total of 26 field blanks (appendix A4-3) and 26 replicate samples (appendix A4-4) were collected during surface-water sampling. One replicate sample was obtained during the collection of precipitation samples at site RG-02. Approximately 13 percent of the total number of samples collected during the study were quality-control samples. All surface-water blank and replicate samples were analyzed for nutrients and major ions. Stable isotopes of water $\left(\delta^{2} \mathrm{H}\right.$ and $\delta^{18} \mathrm{O}$ ) were measured in replicate samples collected at the primary study sites and in the one precipitation replicate. Stable isotopes of nitrate+nitrite $\left(\delta^{15} \mathrm{~N}\right.$ and $\left.\delta^{18} \mathrm{O}\right)$ were measured in most surface-water replicate samples having detectable concentrations of nitrate+nitrite above the RL of $0.04 \mathrm{mg} / \mathrm{L}$.

Most constituents were below analytical RLs in the field blanks (appendix A4-3). Magnesium, sodium, potassium, and sulfate were not detected in any blank samples. Concentrations of calcium and chloride in one blank sample $(0.037$ and $0.11 \mathrm{mg} / \mathrm{L}$, respectively) were an order of magnitude lower than calcium and chloride concentrations measured in 
environmental samples (appendix A4-1). For nutrients, ortho-P was not detected in any blanks. Nitrate+nitrite was detected in one blank sample at a concentration $(0.070 \mathrm{mg} / \mathrm{L})$ just above the RL of $0.040 \mathrm{mg} / \mathrm{L}$. Total phosphorus was also detected in one blank sample at a concentration $(0.005 \mathrm{mg} / \mathrm{L})$ just above the RL of $0.004 \mathrm{mg} / \mathrm{L}$. Ammonia+organic $\mathrm{N}$ was detected in about 12 percent of the blank samples (3 of 26) at concentrations of 0.08 to $0.14 \mathrm{mg} / \mathrm{L}$; however, there was no indication of systematic bias that would affect the environmental results. All ammonia+organic $\mathrm{N}$ concentrations measured for the environmental samples (appendix A4-1) exceeded the greatest concentration of $0.14 \mathrm{mg} / \mathrm{L}$ detected in the blank samples (appendix A4-3).

Ammonia was detected in about 27 percent of the blank samples (7 of 26) at concentrations of 0.011 to $0.020 \mathrm{mg} / \mathrm{L}$. Blank samples frequently may become contaminated with ammonia when exposed to the atmosphere - both in the field and laboratory (Fishman, 1993). This is especially apparent when blanks are analyzed using low-level techniques, as was done in this study. Although some low-level contamination of ammonia may have occurred, any effects on the environmental data are considered minimal. Of the 344 total environmental samples, 319 had concentrations of ammonia above the analytical RL of $0.010 \mathrm{mg} / \mathrm{L}$ (appendix A4-1). Approximately 89 percent of these samples (283 of 319 ) had ammonia concentrations that exceeded the highest ammonia concentration of $0.020 \mathrm{mg} / \mathrm{L}$ detected in the blank samples (appendix A4-3). In addition, 75 percent of the samples (241 of 319) had ammonia concentrations greater than $0.040 \mathrm{mg} / \mathrm{L}$, more than twice the highest concentration of $0.020 \mathrm{mg} / \mathrm{L}$ detected in the blanks.

Replicate samples were used to assess the overall precision of the entire sample collection, handling, and analysis approach. A statistical summary of the relative percent difference (RPD) determined for each analyte for all paired environmental and replicate samples is provided in table 6 . The RPDs in analyte concentrations rarely exceeded 15 percent. Exceedances above 15 percent were limited to one or two replicate sample pairs for sulfate, nitrate+nitrite, total $\mathrm{P}$, and $\delta^{18} \mathrm{O}$ of nitrate+nitrite. The mean and median RPDs were less than about 5 percent for all the measured constituents (table 6), which indicates very good agreement between the environmental and replicate samples.

Prior to data analysis, the water-quality data (appendix A4-1) were reviewed to identify any obvious outliers or potential issues in the sample results. Site SW-02 was noted to have the highest measured values for specific conductance and the major ions, by up to an order of magnitude, among any of the study sites (appendix A4-1). Nutrient results for site SW-02 were similar to the other study sites. Site SW-02 contains both one small swine CAFO (1 barn with 4,330 swine) and a granite quarry in the headwater area of the watershed (appendix fig. A1-20). The very high ion concentrations for site SW-02 are suspected of being influenced by mining activities associated with the quarry; therefore, the results for specific conductance, calcium, magnesium, sodium, potassium, chloride, and sulfate for this site were excluded from data analyses in this report. Results for the August 26, 2012, sample collected at site BK-01 (appendix A4-1) were excluded from data evaluations because they were considered to be influenced by backwater conditions from the adjacent Roanoke River (appendix fig. A1-1) when storm runoff increased river levels by about $8 \mathrm{ft}$ between August 25-26, 2012. In addition, the $\delta^{2} \mathrm{H}$ and $\delta^{18} \mathrm{O}$ isotopic results for sites BK-17 (appendix fig. A1-17) and SW-11 (appendix fig. A1-29), which were influenced by upstream impoundments, were considered atypical and also were excluded from the data evaluations.

Table 6. Statistical summary of relative percent differences in analyte concentrations for the environmental and replicate sample sets.

[RPD, relative percent difference; $\%$, percent; $\mathrm{N}$, nitrogen; $\mathrm{P}$, phosphorus; $\delta$, delta]

\begin{tabular}{|c|c|c|c|c|c|}
\hline \multirow[b]{2}{*}{ Analyte } & \multirow[b]{2}{*}{$\begin{array}{l}\text { Number of paired } \\
\text { replicate samples }\end{array}$} & \multicolumn{4}{|c|}{ Statistical measure } \\
\hline & & $\begin{array}{c}\text { Minimum } \\
\text { RPD (\%) }\end{array}$ & $\begin{array}{c}\text { Maximum } \\
\text { RPD (\%) }\end{array}$ & $\begin{array}{c}\text { Mean RPD } \\
(\%)\end{array}$ & $\begin{array}{c}\text { Median RPD } \\
(\%)\end{array}$ \\
\hline Calcium, dissolved & 26 & 0.0 & 5.6 & 1.4 & 1.0 \\
\hline Magnesium, dissolved & 26 & 0.0 & 5.7 & 1.3 & 1.2 \\
\hline Sodium, dissolved & 26 & 0.0 & 4.6 & 2.0 & 1.9 \\
\hline Potassium, dissolved & 26 & 0.0 & 8.3 & 2.7 & 2.2 \\
\hline Chloride, dissolved & 26 & 0.0 & 1.8 & 0.3 & 0.0 \\
\hline Sulfate, dissolved & 26 & 0.0 & 16.6 & 1.2 & 0.4 \\
\hline Ammonia + organic nitrogen as $\mathrm{N}$, total & 26 & 0.0 & 10.7 & 2.6 & 1.4 \\
\hline Ammonia as $\mathrm{N}$, dissolved & 22 & 0.0 & 5.6 & 1.8 & 1.1 \\
\hline Nitrate + nitrite as $\mathrm{N}$, dissolved & 19 & 0.0 & 18.6 & 5.3 & 1.9 \\
\hline Orthophosphate as $\mathrm{P}$, dissolved & 21 & 0.0 & 14.0 & 2.8 & 1.4 \\
\hline Phosphorus as $\mathrm{P}$, total & 26 & 0.0 & 35.0 & 4.1 & 1.4 \\
\hline$\delta$ Hydrogen- 2 of water, dissolved & 25 & 0.0 & 6.2 & 2.7 & 2.6 \\
\hline$\delta$ Oxygen-18 of water, dissolved & 25 & 0.0 & 2.4 & 0.8 & 0.7 \\
\hline$\delta$ Nitrogen- 15 of nitrate + nitrite, dissolved & 18 & 0.2 & 10.8 & 1.6 & 0.7 \\
\hline$\delta$ Oxygen-18 of nitrate + nitrite, dissolved & 18 & 0.0 & 28.8 & 3.8 & 1.5 \\
\hline
\end{tabular}

${ }^{1}$ Relative percent differences were computed when both samples in a pair had concentrations above analytical reporting levels. 


\section{Statistical Analyses}

Statistical evaluations of the study data included the use of analysis of variance (ANOVA) tests and pair-wise multiple-comparison tests (Helsel and Hirsch, 1992). One-way ANOVA tests were used to test for significant differences in watershed attributes, such as basin drainage area, among the three watershed land-use types (BK, SW, and SP). Two-way, or multifactor, ANOVA tests were used to test for significant differences in surface-water constituents on the basis of sampling period and (or) land-use type. Because most of the study data are non-normally distributed, a non-parametric approach was used in which the ANOVA tests were performed on rank-transformed data to assess differences between groups. The use of statistical analyses that rely on data ranks, rather than actual data values, also is appropriate for examining water-quality data containing left-censored " $<$ " values when the $<$ values for a given constituent are censored to the same analytical RL (Bonn, 2008). Left-censored values reported for ammonia, nitrate+nitrite, and ortho-P in surface-water samples (appendix A4-1) were set equal to their respective RLs prior to ranking the data for use in statistical analyses.

Constituent concentrations were ranked for all samples collected from the 54 primary study sites during the 6 sampling periods. A two-way ANOVA test was then performed on the ranks of the concentration data to test for differences based on the grouping (or explanatory) variables of sampling period (June, August, October, and December in 2012, and February and April in 2013) and land-use type (including the $18 \mathrm{BK}, 18 \mathrm{SW}$, and $18 \mathrm{SP}$ sites). By evaluating sampling period and land-use type simultaneously, the effect of one explanatory variable can be measured while compensating for the other. The test compares the mean ranks of the constituent concentrations in the treatment groups to the overall mean rank for the entire dataset and determines whether there is an influential effect based on sampling period, land-use type, and (or) the combined interaction between sampling period and land-use type.

The ANOVA results for a given constituent may indicate that a statistically significant difference in the mean ranks of the concentrations exists among a particular treatment group (such as land-use type); however, it does not specify which of the group treatments (such as BK, SW, and SP site types) are different. Those constituents with significant differences identified by the ANOVA tests were analyzed further with Tukey pair-wise multiple-comparison tests to identify which sampling period comparison pairs and (or) land-use type comparison pairs had statistically different means in their ranked values. The ANOVA and pair-wise multiple-comparison analyses, which were tested at the 95 percent confidence level $(\mathrm{P}=0.05)$, were conducted using the $\mathrm{S}$-Plus software suite (by TIBCO Software Inc.).

Relations of environmental variables among study sites identified as either being influenced or not influenced by CAFO waste manures were modeled using classification tree analyses (Breiman and others, 1984). Classification tree-based modeling is an exploratory technique for uncovering structure in the data. The classification tree models evaluate the response variable, or defined category (such as sites without CAFO effects and sites with CAFO effects), and the associated predictor variables (such as environmental attributes) to identify the predictor variables that best partition, or split, the response variable into increasingly homogeneous subsets. The resulting classification tree is simplified (pruned) by removing splits that do not contribute to a reduction in model error. The classification tree analyses were conducted using the S-Plus software suite (by TIBCO Software Inc.).

\section{Characterization of Watershed Settings and Hydrologic Conditions}

Information compiled on land cover, hydrologic soil groups (HSGs), and CAFO attributes was used to examine watershed settings among the study sites. Regional information on precipitation and streamflows and measurements of stable isotopes of water in collected samples were used to characterize general hydrologic conditions during the six water-quality sampling periods.

\section{Watershed Settings}

Land cover, HSGs, and CAFO attributes (appendixes A2-1, A2-2, A3-5 and A3-7) for the primary study sites were evaluated to identify similarities or differences in watershed settings among the BK, SW, and SP site groups. Land cover and HSGs were examined among all three site groups.

Attributes for swine CAFOs were examined only for the SW and SP groups. A statistical summary of watershed attributes in each site group is provided in table 7.

The overall results of the statistical analyses indicate that the general watershed settings of the study sites are comparable among the BK, SW, and SP site groups. The primary difference between the land-use groups is that the BK sites contain no CAFOs, the SW sites contain swine CAFOs, and the SP sites contain both swine and poultry CAFOs. ANOVA tests indicated few statistical differences in land cover and HSGs among the BK, SW, and SP site groups (table 8). Shrub land cover, HSG total A, and HSG D were the only watershed attributes that were significantly different $(\mathrm{P}<0.05)$ between some site groups. In addition, the ANOVA tests also did not identify any statistically significant differences $(\mathrm{P}<0.05)$ in any of the swine CAFO attributes examined between the SW and SP site groups (table 8). In other words, the SW and SP groups are similar with respect to swine $\mathrm{CAFO}$ attributes in the watersheds but differ in that poultry CAFOs also are present only in the SP watersheds (table 7). 
Table 7. Statistical summary of watershed attributes by land-use type.

[n, number; $\mathrm{mi}^{2}$, square mile; \%, percent; CAFO, concentrated animal feeding operation; PAN, plant available nitrogen; SSLW, steady state live weight; na, not applicable]

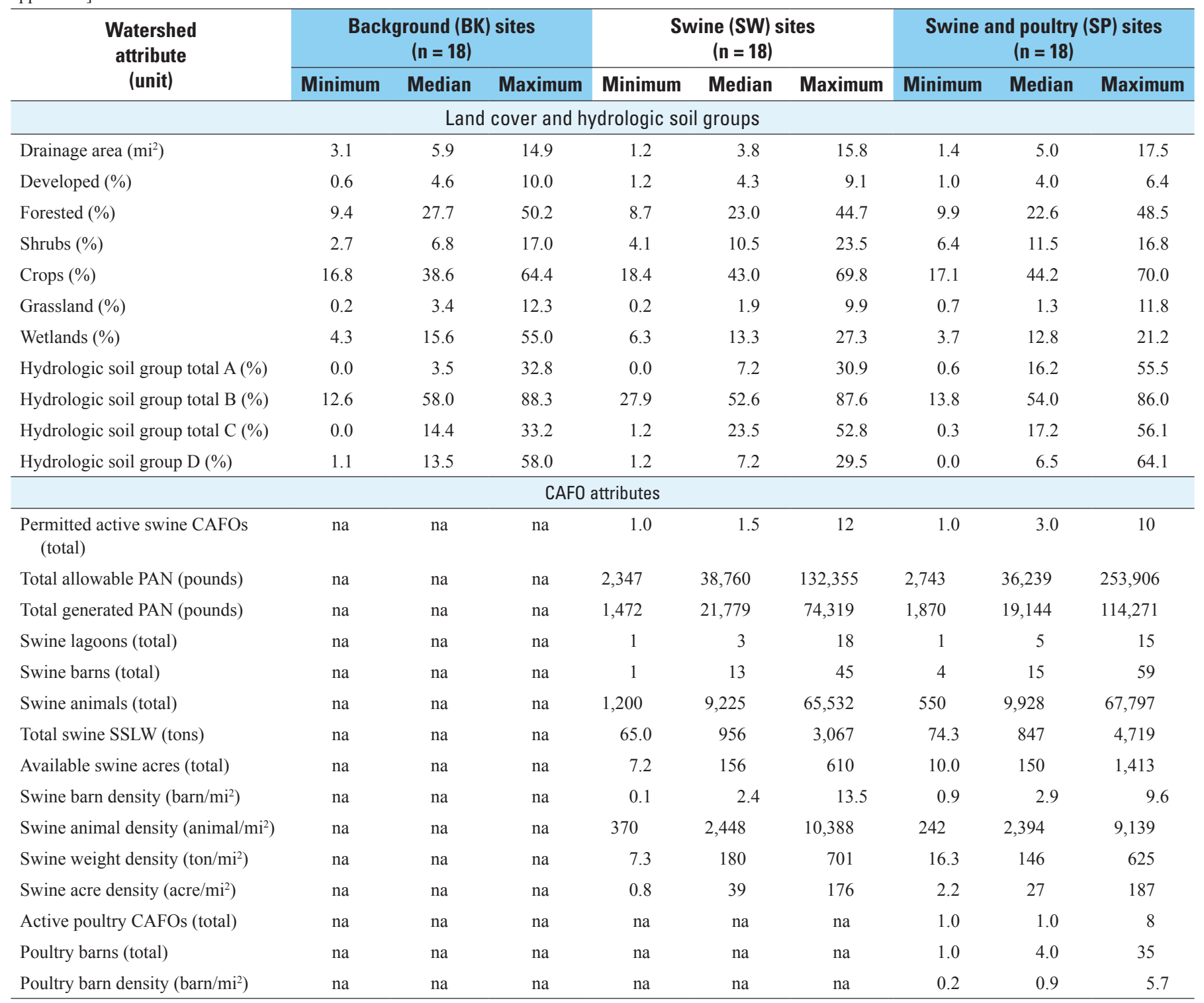


Table 8. Summary results of the ANOVA and Tukey multiple-comparison tests of watershed attributes by land-use type.

[The null hypothesis was that the mean ranks of each distribution were the same. ANOVA, analysis of variance; *, indicates significant difference $(\mathrm{P}<0.05)$; ns, no significant differences between site types based on ANOVA test; BK, background site type; SW, swine site type; SP, swine and poultry site type; CAFO, concentrated animal feeding operation; PAN, plant available nitrogen; SSLW, steady state live weight]

\begin{tabular}{|c|c|c|}
\hline \multirow{2}{*}{ Watershed attribute } & \multirow{2}{*}{$\begin{array}{c}\text { ANOVA test } \\
\text { p-value }\end{array}$} & \multirow{2}{*}{\begin{tabular}{|c|} 
Tukey multiple-comparison test \\
Site-type comparison pairs significant at $\alpha=0.05$
\end{tabular}} \\
\hline & & \\
\hline \multicolumn{3}{|c|}{ Land cover and hydrologic soil groups } \\
\hline Developed & 0.7661 & ns \\
\hline Forested & 0.3564 & ns \\
\hline Crops & 0.2529 & ns \\
\hline Grassland & 0.0920 & ns \\
\hline Wetlands & 0.3126 & ns \\
\hline Hydrologic soil group total A & $0.0005^{*}$ & BK-SP and SW-SP \\
\hline Hydrologic soil group total B & 0.4401 & ns \\
\hline Permitted active swine CAFOs & 0.0768 & ns \\
\hline Total allowable PAN & 0.7332 & ns \\
\hline Total generated PAN & 0.5980 & ns \\
\hline Swine lagoons & 0.2239 & ns \\
\hline Swine barns & 0.2530 & ns \\
\hline Swine animals & 0.3183 & ns \\
\hline Total swine SSLW & 0.6870 & ns \\
\hline Available swine acres & 0.8770 & ns \\
\hline
\end{tabular}




\section{Hydrologic Conditions During Sampling}

Typical site conditions during sampling at most of the study sites included low streamflow velocity coupled with varying degrees of submerged and floating aquatic vegetation within and along the stream channel. Because of these conditions, it was not feasible to measure stream discharge at the study sites during sampling. Therefore, regional precipitation and streamflow data collected at active USGS monitoring stations (tables 3, 4; fig. 2), as well as $\delta^{2} \mathrm{H}$ and $\delta^{18} \mathrm{O}$ isotopic results for precipitation and stream samples, were used to assess general hydrologic conditions in the study area during the six sampling periods (June, August, October, and December in 2012, and February and April in 2013).

\section{Precipitation}

Regional precipitation measured during the study at the raingage monitoring sites (table 3 ; fig. 2) was slightly below normal levels. The annual precipitation recorded from May 1, 2012, through April 30, 2013, at raingage sites RG-01 (35.77 inches [in.]), RG-02 (40.49 in.), RG-03 (47.98 in.), and RG-04 (48.34 in.) has an average value of 43.14 in. Note that the annual values for RG-01 and RG-03 represent a lower limit because these sites had 17 days and 3 days, respectively, of missing data where precipitation was not recorded. The average annual precipitation is $45.60 \mathrm{in}$. if site RG-01 is excluded. Normal average annual precipitation in the study area, based on the 30-year period 1971-2000, ranges from about 46 to 52 in. (State Climate Office of North Carolina, n.d.).

Mean 7-day precipitation totals were used to document the differences in the amount of rainfall in the study area among the water-quality sampling periods (table 9; fig. 3). Overall, antecedent field conditions for the sampling periods were wetter for August and February, intermediate for June and April, and drier for October and December. It is important to note that for a given sampling event, there may have been considerable local differences in precipitation amounts among the study sites. For example, scattered thunderstorms occurred throughout the study area for the August period. The uneven distribution of precipitation is reflected by the higher standard deviations associated with the mean 7-day precipitation totals for August relative to the other sampling periods (table 9). The February sampling dates had mean 7-day precipitation totals similar to the August sampling dates, yet the lower standard deviations suggest that precipitation was more uniform across the study area during the February sampling event.

Table 9. Summary of the cumulative 7-day precipitation totals preceding each sample collection date based on raingage monitoring sites $\mathrm{RG}-01, \mathrm{RG}-02, \mathrm{RG}-03$, and RG-04 (site locations in figure 2 and table 3).

\begin{tabular}{|c|c|c|c|c|c|}
\hline \multirow{2}{*}{ Sample date } & \multirow{2}{*}{$\begin{array}{l}\text { Number of primary } \\
\text { study sites sampled }\end{array}$} & \multicolumn{4}{|c|}{ 7-day precipitation total (inches) } \\
\hline & & Minimum & Maximum & Mean & Standard deviation \\
\hline $06 / 13 / 12$ & 10 & 0.20 & 0.83 & 0.51 & 0.32 \\
\hline $06 / 14 / 12$ & 12 & 0.20 & 0.83 & 0.51 & 0.32 \\
\hline $06 / 15 / 12$ & 8 & 0.20 & 0.83 & 0.51 & 0.32 \\
\hline $06 / 18 / 12$ & 12 & 0.20 & 0.83 & 0.51 & 0.32 \\
\hline $06 / 19 / 12$ & 12 & 0.11 & 0.46 & 0.23 & 0.20 \\
\hline $08 / 26 / 12$ & 22 & 1.10 & 3.18 & 2.01 & 0.89 \\
\hline $08 / 27 / 12$ & 23 & 1.13 & 2.39 & 1.80 & 0.52 \\
\hline $08 / 28 / 12$ & 8 & 1.04 & 2.33 & 1.72 & 0.53 \\
\hline $10 / 21 / 12$ & 14 & 0.12 & 0.18 & 0.16 & 0.03 \\
\hline $10 / 22 / 12$ & 17 & 0.12 & 0.18 & 0.16 & 0.03 \\
\hline $10 / 23 / 12$ & 17 & 0.00 & 0.08 & 0.04 & 0.04 \\
\hline $10 / 24 / 12$ & 4 & 0.00 & 0.08 & 0.03 & 0.04 \\
\hline $12 / 09 / 12$ & 13 & 0.01 & 0.17 & 0.07 & 0.07 \\
\hline $12 / 10 / 12$ & 23 & 0.01 & 0.17 & 0.08 & 0.07 \\
\hline $12 / 11 / 12$ & 14 & 0.01 & 0.17 & 0.08 & 0.07 \\
\hline $12 / 12 / 12$ & 4 & 0.01 & 0.25 & 0.10 & 0.10 \\
\hline $02 / 11 / 13$ & 19 & 1.51 & 1.88 & 1.70 & 0.19 \\
\hline $02 / 12 / 13$ & 24 & 1.57 & 2.11 & 1.84 & 0.24 \\
\hline $02 / 13 / 13$ & 11 & 1.57 & 2.25 & 1.91 & 0.28 \\
\hline $04 / 17 / 13$ & 2 & 0.67 & 0.76 & 0.73 & 0.04 \\
\hline $04 / 18 / 13$ & 7 & 0.67 & 0.76 & 0.73 & 0.04 \\
\hline $04 / 19 / 13$ & 2 & 0.67 & 0.76 & 0.73 & 0.04 \\
\hline $04 / 21 / 13$ & 9 & 0.76 & 0.94 & 0.84 & 0.08 \\
\hline $04 / 22 / 13$ & 21 & 0.76 & 0.94 & 0.84 & 0.08 \\
\hline $04 / 23 / 13$ & 13 & 0.59 & 1.13 & 0.81 & 0.23 \\
\hline
\end{tabular}




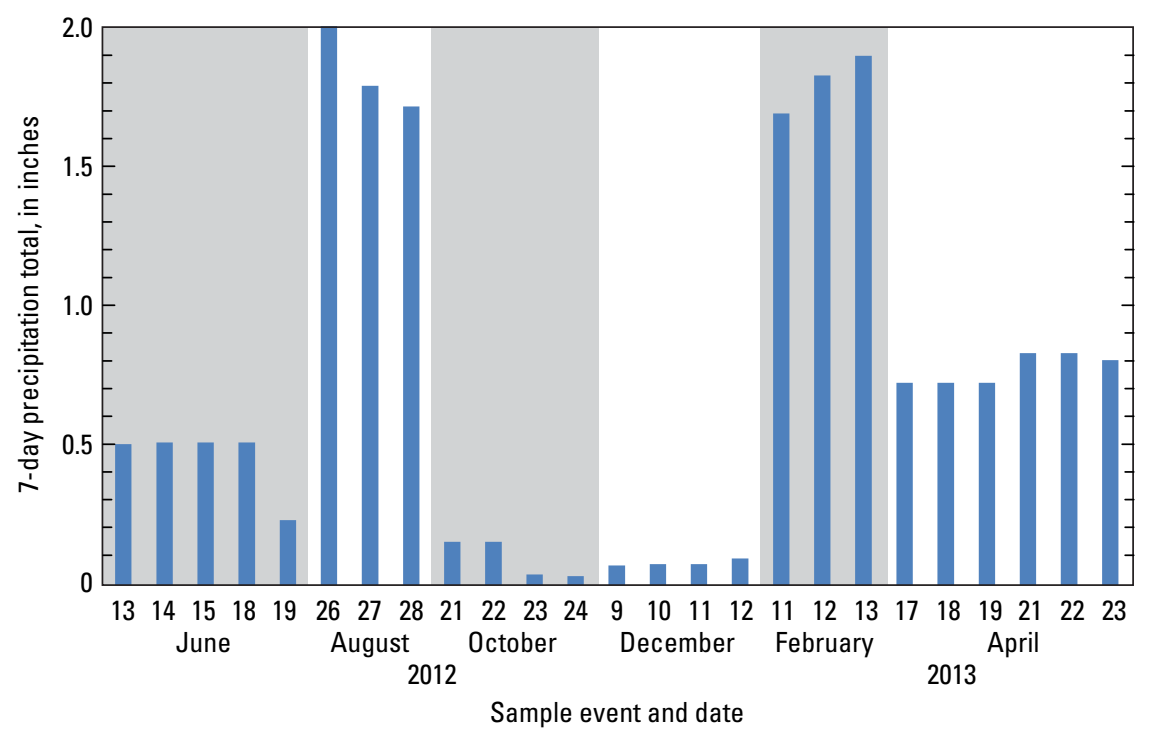

Figure 3. Mean cumulative 7-day precipitation totals preceding each sample collection date based on raingage monitoring sites RG-01, RG-02, RG-03, and RG-04 (site locations in figure 2 and table 3).

\section{Streamflow}

Relative differences in regional streamflow conditions during the water-quality sampling periods were inferred from streamflow records from six streamgage sites distributed throughout the study area (figs. 2, 4). The streamgage sites represent basin drainage areas ranging from 45 to $599 \mathrm{mi}^{2}$. Drainage areas for the primary study sites are considerably smaller, ranging from 1.2 to $17.5 \mathrm{mi}^{2}$. Although the magnitude of streamflow and the duration and timing of peak streamflows likely differ between the streamgage sites and the study sites, the hydrographs are useful indicators of relative streamflow trends throughout the study area during the sampling periods and the entire study period.

Streamflow conditions during most of the sampling periods were similar to or higher than historical streamflow conditions in the study area. Daily mean streamflows at the six streamgage sites during the study period (May 2012 through April 2013) are shown relative to long-term median daily mean streamflows for the 25-year period from May 1988 through April 2013 (fig. 4). In general, streamflows for the June, October, and April sampling periods were fairly similar to the long-term median values. Streamflows for the August and February periods tended to be substantially higher, and streamflows for the December period tended to be substantially lower relative to historical conditions.

Streamflow conditions varied among the six sampling periods (fig. 4). Compared to other sampling periods, streamflow conditions were relatively higher during the August and February sampling periods when precipitation amounts in the study area were higher (fig. 3) and overland transport of water to the streams was greater. The intermediate to lower streamflow conditions for the June, October, December, and April sampling periods reflect less precipitation and overland transport of water to the streams and a larger component of streamflow derived from groundwater compared to the August and February periods. The typically higher and more sustained stream-baseflow conditions (fig. 4) observed during the winter and early spring months (generally January to April) reflect greater groundwater discharge and likely higher inputs from field drainage ditches when the water table in the surficial aquifers is high. Variations in stream water quality at the study sites among sampling periods with higher versus lower relative streamflows may reflect relative differences in source contributions of water-quality constituents delivered through groundwater discharge and overland runoff. 

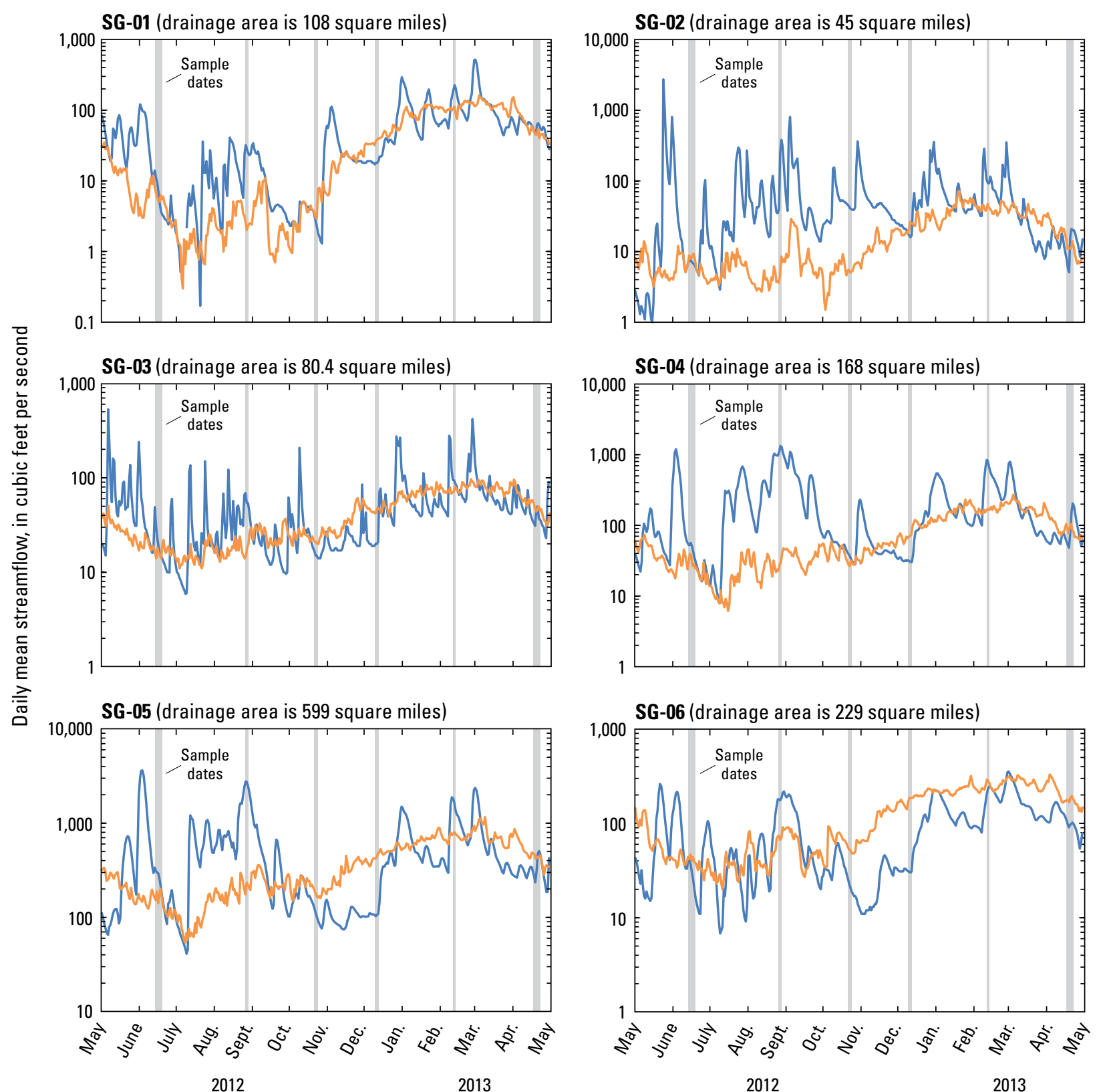

2012

2013

\section{EXPLANATION}

Daily mean streamflow during study period from May 2012 through April 2013

Historical median daily mean streamflow for 25 -year period from

May 1988 through April 2013

Figure 4. Streamflow hydrographs at sites SG-01, SG-02, SG-03, SG-04, SG-05, and SG-06 showing dates water-quality samples were collected during the study and historical median daily mean streamflows (site locations in figure 2 and table 4). 


\section{Water Stable Isotopes}

Stable isotopes of water $\left(\delta^{2} \mathrm{H}\right.$ and $\left.\delta^{18} \mathrm{O}\right)$ in precipitation and stream samples also were used to characterize general hydrologic conditions during the sampling periods. The $\delta^{2} \mathrm{H}$ and $\delta^{18} \mathrm{O}$ data for precipitation samples collected from July 2012 to April 2013 at rainfall monitoring sites RG-01 and RG-02 (fig. 2; appendix A4-2) were used to create a local meteoric water line (LMWL) for the Coastal Plain study area (fig. 5). The LMWL is represented by the linear relation between the $\delta^{2} \mathrm{H}$ and $\delta^{18} \mathrm{O}$ isotopic compositions in the precipitation samples:

$$
\delta^{2} \mathrm{H}=8.33 * \delta^{18} \mathrm{O}+16.75
$$

The slope of 8.33 for the LMWL determined in this study is similar to the meteoric water line (MWL) equation $\left(\delta^{2} \mathrm{H}=8.29 * \delta^{18} \mathrm{O}+10.94\right)$ determined by Kendall and Coplen (2001) using average values of surface-water samples obtained from 391 sites throughout the United States and Puerto Rico.

The $\delta^{2} \mathrm{H}$ and $\delta^{18} \mathrm{O}$ isotopic compositions of the samples collected at the primary sites (appendix A4-1) were compared to the LMWL to examine general differences in stream hydrologic conditions during the sampling periods (fig. 6). In general, surface-water samples with $\delta^{2} \mathrm{H}$ and $\delta^{18} \mathrm{O}$ values that correspond to the LMWL indicate that water in the streams reflects more recent inputs of precipitation to the land surface, which ultimately reaches the streams through runoff and groundwater discharge, that has undergone little fractionation. Samples with $\delta^{2} \mathrm{H}$ and $\delta^{18} \mathrm{O}$ values that plot along a line with a slope lower than the LMWL can be an indication that post-rainfall processes, commonly evaporation, altered the isotopic composition of the stream water prior to sample collection (Kendall and Coplen, 2001). As surface water evaporates, there is a preferential release of the lighter ${ }^{1} \mathrm{H}$ and ${ }^{16} \mathrm{O}$ isotopes to the atmosphere, which increases the $\delta^{2} \mathrm{H}$ and $\delta^{18} \mathrm{O}$ values of the remaining stream water; the values become increasingly more positive as evaporation proceeds.

During the six sampling periods, the $\delta^{2} \mathrm{H}$ and $\delta^{18} \mathrm{O}$ values for the February 2013 stream samples corresponded most closely to the LMWL (fig. $6 E$ ), reflecting the recent inputs of overland runoff when evaporation was least likely to have occurred (figs. 3, 4). The regression line for the February 2013 samples, with a slope of 6.97, almost paralleled the LMWL. For reference purposes, the regression line for the February 2013 data was superimposed on each of the $\delta^{2} \mathrm{H}$ and $\delta^{18} \mathrm{O}$ isotopic plots for the other five periods (fig. 6) to relate the isotopic compositions for those periods to the February period. The $\delta^{2} \mathrm{H}$ and $\delta^{18} \mathrm{O}$ values for the August 2012 samples plotted along a line with a slope of 6.08 (fig. $6 B$ ) that was just below the slope of 6.97 for the February 2013 period. The August samples had the largest observed range in $\delta^{2} \mathrm{H}$ values $(-12.3$ to $-37.3 \%)$ and $\delta^{18} \mathrm{O}$ values $(-2.3$ to $-6.5 \%$ ). The August samples in the lower part of the regression line had isotopic signatures similar to the LMWL, indicating that stream water at some of the sites had received recent inputs of overland runoff and was minimally influenced by evaporation. August samples in the upper part of the regression line had more positive isotope $\delta^{2} \mathrm{H}$ and $\delta^{18} \mathrm{O}$ values that diverged to the right of the LMWL (fig. $6 B$ ), reflecting increased effects of evaporation and a lack of recent runoff at some of the sites sampled during August.

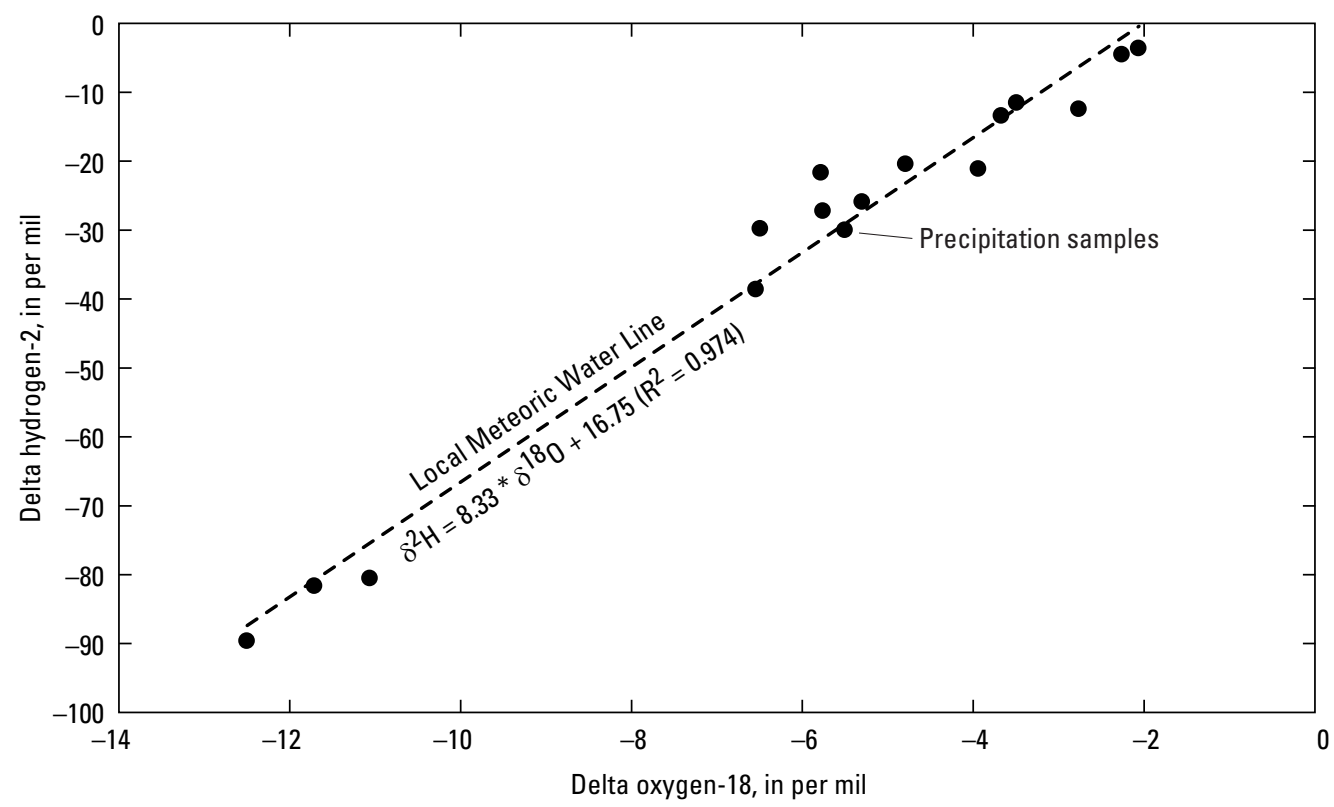

Figure 5. Comparison of delta oxygen-18 to delta hydrogen-2 isotope values in precipitation samples collected from July 2012 to April 2013 at raingage sites RG-01 and RG-02 in the Coastal Plain study area. 

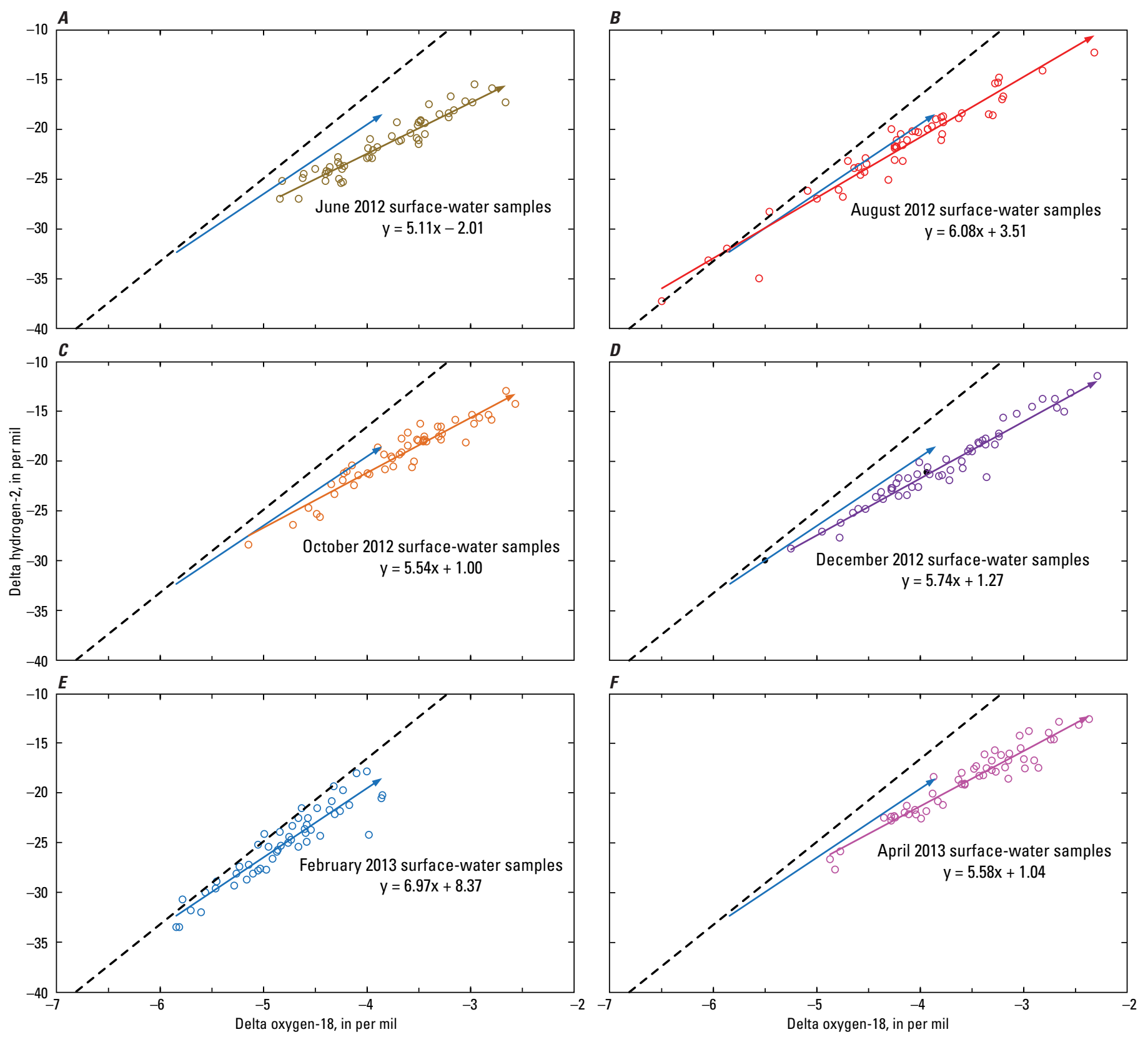

EXPLANATION

$\longrightarrow$ Regression line for February 2013 samples
$\longrightarrow$ Real meteoric water line

Figure 6. Comparisons of delta oxygen-18 to delta hydrogen-2 isotope values of surface-water samples for the $(A)$ June 2012, (B) August 2012, (C) October 2012, (D) December 2012, (E) February 2013, and (F) April 2013 sampling periods relative to the local meteoric water line. 
More pronounced effects of evaporation on the isotopic compositions at the stream sites were noted for the June, October, and December 2012 periods and the April 2013 period where the $\delta^{2} \mathrm{H}$ and $\delta^{18} \mathrm{O}$ values, with regression line slopes ranging from 5.11 to 5.74, plotted farthest away from the LMWL (fig. 6). These results support the previous discussion of the precipitation and streamflow data, which implied that streamflow conditions were relatively higher during the August and February periods as a result of increased rainfall and overland runoff (figs. 3, 4). Evaporation appeared to have a more influential effect on the surface-water $\delta^{2} \mathrm{H}$ and $\delta^{18} \mathrm{O}$ compositions during the June, October, December, and April periods. These periods were characterized by intermediate to lower streamflow conditions when there was less rainfall runoff to the streams and proportionally more input from discharging groundwater.

\section{Comparison of Water-Quality Data by Sampling Period and Land-Use Type}

Two-way ANOVA and multiple-comparison statistical tests were performed to characterize differences in stream water quality among the sampling periods (June, August, October, and December in 2012, and February and April in 2013) and watershed land-use types (BK, SW, and SP). Many of the water-quality properties and constituents were significantly influenced (ANOVA $\mathrm{P}<0.05$ ) by one or both of the explanatory variables (sampling period and (or) land-use type) but there were no effects due to their combined interaction (sampling period:land-use type) (table 10). The lack of interaction indicates that the effects of sampling period and land-use type for a given constituent are independent; in other words, the effect of sampling period is the same across all land-use types and the effect of land-use type is the same across all sampling periods.

\section{Seasonal and Flow-Related Water-Quality Differences}

All of the water-quality properties and constituents, except calcium and the nitrate+nitrite isotopes $\left(\delta^{15} \mathrm{~N}\right.$ and $\left.\delta^{18} \mathrm{O}\right)$, had significant (ANOVA, $\mathrm{P}<0.05$ ) differences among the sampling periods (table 10) based on data collected at the 54 primary sites. Differences reflected seasonal and hydrologic variations, as well as instream processes. Statistical summaries, by sampling period, of the original (non-ranked transformed) water-quality data are provided in tabular (table 11) and graphical formats (fig. 7) to aid the discussion. Figure 7 contains box plots for properties and constituents with significant differences (ANOVA $\mathrm{P}<0.05$ ) among sampling periods; results of the multiple-comparison tests among the periods are denoted along the top of the plots. Rather than scrutinizing individual comparison pairs, the following discussion focuses on patterns among the sampling periods that reflect seasonal and hydrologic influences on water quality. Although ANOVA indicated a significant $(\mathrm{P}=0.039)$ difference for magnesium among sampling period (table 10), the multiple-comparison test did not identify any comparison pairs that were considered $(\mathrm{P}<0.05)$ different.

Water temperature followed an expected seasonal progression (fig. 7A). Specific conductance values were relatively lower during the August and February periods when rainfall was greatest, and higher for the October and December periods, when rainfall was least, although the difference was significant only for the December period (fig. 7B). Specific conductance in streams commonly is lower during high streamflows through dilution from overland runoff, and higher during low streamflows when baseflow, or groundwater discharge, is a larger component of the overall streamflow. Sodium (fig. $7 E$ ), potassium (fig. $7 F$ ), and chloride concentrations (fig. $7 G$ ) had distributions similar to specific conductance (fig. $7 B$ ) with highest concentrations during the drier December period.

In well-mixed, open flowing streams, DO concentrations typically are higher at cold temperatures and lower at warm temperatures. This is a result of higher solubility of dissolved gases in water at low temperatures. Although water temperatures (fig. 7A) followed expected seasonal patterns among the six sampling periods, there was no apparent relation between water temperature and DO (fig. 7C), with the exception of the February period. The streams examined in this study typically are slow moving and enriched with organic matter; low levels of DO are common in these stream settings. The variations in DO concentrations observed among the sampling periods likely reflect the integrated effects of hydrologic differences, such as the influx of oxygenated water from precipitation and overland runoff, and seasonal differences in the consumption of DO by microbial degradation of organic matter. The higher flow conditions for the February and August periods and intermediate flow conditions for the April period indicate more recent stream influxes of precipitation and runoff and, hence oxygenated water, were associated with these periods relative to the June, October, and December periods. The twofold difference in median DO concentrations between the February $(8.0 \mathrm{mg} / \mathrm{L})$ and August $(3.6 \mathrm{mg} / \mathrm{L})$ periods with the highest flow conditions appears to reflect seasonal differences in the microbial consumption of oxygen for degrading organic matter, which proceeds more quickly under warmer conditions and more slowly under cooler conditions. Although water temperatures were lower for October and December relative to August, the similarly low median DO concentrations for the drier October $(2.4 \mathrm{mg} / \mathrm{L})$ and December $(2.1 \mathrm{mg} / \mathrm{L})$ periods suggest that a substantial amount of microbial oxygen consumption occurred during the more sluggish streamflow conditions.

Concentrations of nutrients also differed among the sampling periods (table 10; fig. 7). Many biological, chemical, and physical processes can influence the forms and instream concentrations of the $\mathrm{N}$ and $\mathrm{P}$ constituents, 
Table 10. Summary results of the two-way ANOVA tests on the ranked values of the water-quality properties and constituents based on sampling period and land-use type. [The null hypothesis was that the mean ranks of each distribution were the same. *, indicates significant difference $(\mathrm{P}<0.05) ;<$, less than; $\mathrm{N}$, nitrogen; $\mathrm{P}$, phosphorus; $\delta$, delta]

\begin{tabular}{|c|c|c|c|c|c|c|c|c|c|c|}
\hline \multirow{2}{*}{$\begin{array}{c}\text { Explanatory } \\
\text { grouping variable }\end{array}$} & \multicolumn{4}{|c|}{ p-values for water-quality properties } & \multicolumn{6}{|c|}{ p-values for major ions } \\
\hline & $\begin{array}{c}\text { Water } \\
\text { temperature }\end{array}$ & $\begin{array}{c}\text { Specific } \\
\text { conductance }\end{array}$ & $\begin{array}{c}\text { Dissolved } \\
\text { oxygen }\end{array}$ & pH & Calcium & Magnesium & Sodium & Potassium & Chloride & Sulfate \\
\hline Sampling period & $<0.001 *$ & $0.001 *$ & $<0.001 *$ & $0.015^{*}$ & 0.220 & $0.039 *$ & $<0.001 *$ & $<0.001 *$ & $<0.001 *$ & $<0.001^{*}$ \\
\hline Land-use type & 0.254 & $<0.001^{*}$ & 0.157 & $<0.001^{*}$ & 0.084 & $<0.001^{*}$ & $<0.001^{*}$ & $<0.001^{*}$ & $<0.001^{*}$ & $<0.001^{*}$ \\
\hline Sampling period:Land-use type & 0.224 & 0.936 & 0.751 & 0.977 & 0.996 & 0.980 & 0.921 & 0.800 & 0.367 & 0.778 \\
\hline
\end{tabular}

\begin{tabular}{|c|c|c|c|c|c|c|c|c|c|}
\hline \multirow[b]{2}{*}{$\begin{array}{c}\text { Explanatory } \\
\text { grouping variable }\end{array}$} & \multicolumn{7}{|c|}{ p-values for nutrients } & \multicolumn{2}{|c|}{ p-values for isotopes } \\
\hline & $\begin{array}{l}\text { Ammonia + } \\
\text { organic N }\end{array}$ & Ammonia & $\begin{array}{c}\text { Total } \\
\text { organic N }\end{array}$ & $\begin{array}{c}\text { Nitrate + } \\
\text { nitrite }\end{array}$ & Total N & Orthophosphate & Total P & $\begin{array}{c}\delta \text { Nitrogen-15 } \\
\text { of nitrate + } \\
\text { nitrite }\end{array}$ & $\begin{array}{c}\delta \text { Oxygen-18 } \\
\text { of nitrate + } \\
\text { nitrite }\end{array}$ \\
\hline Sampling period & $<0.001 *$ & $<0.001 *$ & $<0.001^{*}$ & $<0.001 *$ & $<0.001 *$ & $<0.001 *$ & $<0.001 *$ & 0.625 & 0.484 \\
\hline Land-use type & $0.007 *$ & $<0.001 *$ & 0.166 & $<0.001 *$ & $<0.001^{*}$ & 0.533 & 0.106 & $<0.001^{*}$ & 0.221 \\
\hline Sampling period:Land-use type & 0.322 & 0.405 & 0.335 & 0.906 & 0.457 & 0.755 & 0.726 & 0.954 & 0.721 \\
\hline
\end{tabular}


Table 11. Statistical summary of water-quality properties and constituents by sampling period.

[diss., dissolved; mg/L, milligrams per liter; <, less than; $\mu \mathrm{S} / \mathrm{cm}$, microsiemens per centimeter; ${ }^{\circ} \mathrm{C}$, degrees Celsius, $\mathrm{N}$, nitrogen; $\mathrm{P}$, phosphorus; $\mathrm{O}$, oxygen; \%o, per mil]

\begin{tabular}{|c|c|c|c|c|c|c|c|c|c|c|c|c|}
\hline \multirow{2}{*}{$\begin{array}{l}\text { Chemical } \\
\text { constituent or } \\
\text { property (unit) }\end{array}$} & \multicolumn{4}{|c|}{ June 2012} & \multicolumn{4}{|c|}{ August 2012} & \multicolumn{4}{|c|}{ October 2012} \\
\hline & $\begin{array}{l}\text { Number of } \\
\text { samples }\end{array}$ & Minimum & Median & Maximum & $\begin{array}{l}\text { Number of } \\
\text { samples }\end{array}$ & Minimum & Median & Maximum & $\begin{array}{l}\text { Number of } \\
\text { samples }\end{array}$ & Minimum & Median & Maximum \\
\hline \multicolumn{13}{|c|}{ Water-quality properties } \\
\hline Temperature, water $\left({ }^{\circ} \mathrm{C}\right)$ & 54 & 18.5 & 21.3 & 26.2 & 52 & 20.6 & 23.1 & 27.3 & 52 & 12.1 & 13.9 & 17.8 \\
\hline $\begin{array}{l}\text { Specific conductance } \\
\left(\mu \mathrm{S} / \mathrm{cm} \text { at } 25^{\circ} \mathrm{C}\right)\end{array}$ & 53 & 48 & 121 & 318 & 51 & 49 & 107 & 318 & 51 & 51 & 133 & 440 \\
\hline Oxygen, diss. (mg/L) & 54 & 0.03 & 1.9 & 8.1 & 52 & 0.04 & 3.6 & 6.9 & 52 & 0.02 & 2.4 & 9.2 \\
\hline pH (standard units) & 53 & 4.9 & 6.1 & 7.0 & 52 & 4.7 & 6.1 & 7.2 & 52 & 5.1 & 6.2 & 7.0 \\
\hline \multicolumn{13}{|c|}{ Major ions } \\
\hline Calcium, diss. (mg/L) & 53 & 2.01 & 8.41 & 43.9 & 51 & 1.94 & 6.29 & 27.2 & 51 & 1.94 & 7.63 & 35.6 \\
\hline Magnesium, diss. (mg/L) & 53 & 0.78 & 3.38 & 7.85 & 51 & 0.76 & 2.52 & 6.85 & 51 & 0.80 & 3.42 & 7.81 \\
\hline Sodium, diss. (mg/L) & 53 & 3.74 & 5.99 & 15.1 & 51 & 2.17 & 5.24 & 16.2 & 51 & 3.04 & 6.79 & 36.0 \\
\hline Potassium, diss. (mg/L) & 53 & 0.90 & 4.73 & 17.4 & 51 & 1.49 & 5.27 & 24.2 & 51 & 2.18 & 5.72 & 46.2 \\
\hline Chloride, diss. (mg/L) & 53 & 7.60 & 15.0 & 34.8 & 51 & 5.06 & 12.7 & 35.1 & 51 & 7.05 & 17.6 & 65.3 \\
\hline Sulfate, diss. (mg/L) & 53 & 0.19 & 3.91 & 33.5 & 51 & 0.14 & 5.36 & 29.3 & 51 & 0.14 & 4.34 & 43.0 \\
\hline \multicolumn{13}{|c|}{ Nutrients } \\
\hline $\begin{array}{l}\text { Ammonia }+ \text { organic } \mathrm{N} \text {, total } \\
\quad(\mathrm{mg} / \mathrm{L} \text { as } \mathrm{N})\end{array}$ & 54 & 0.16 & 1.0 & 2.9 & 52 & 0.60 & 1.0 & 6.3 & 52 & 0.22 & 0.83 & 7.4 \\
\hline Ammonia, diss. (mg/L as N) & 54 & 0.013 & 0.140 & 0.932 & 52 & $<0.010$ & 0.060 & 4.05 & 52 & $<0.010$ & 0.044 & 4.70 \\
\hline Total organic $\mathrm{N}$ (mg/L as $\mathrm{N})$ & 54 & 0.12 & 0.88 & 2.7 & 52 & 0.59 & 0.96 & 2.3 & 52 & 0.21 & 0.75 & 2.7 \\
\hline Nitrate + nitrite, diss. $(\mathrm{mg} / \mathrm{L}$ as $\mathrm{N})$ & 54 & $<0.040$ & 0.066 & 5.97 & 52 & $<0.040$ & 0.123 & 4.28 & 52 & $<0.040$ & 0.049 & 6.66 \\
\hline Total N (mg/L as N) & 54 & 0.20 & 1.3 & 6.8 & 52 & 0.71 & 1.2 & 7.4 & 52 & 0.34 & 1.0 & 14.0 \\
\hline Orthophosphate, diss. (mg/L as P) & 54 & $<0.004$ & 0.039 & 0.461 & 52 & $<0.004$ & 0.042 & 0.399 & 52 & $<0.004$ & 0.029 & 0.466 \\
\hline Total P (mg/L as P) & 54 & 0.020 & 0.140 & 0.981 & 52 & 0.013 & 0.141 & 0.702 & 52 & 0.012 & 0.101 & 0.860 \\
\hline \multicolumn{13}{|c|}{ Isotopes } \\
\hline$\delta^{15} \mathrm{~N}$ of nitrate + nitrite $(\%)$ & 24 & 5.34 & 13.33 & 39.21 & 27 & 5.12 & 12.98 & 48.88 & 22 & 6.24 & 15.42 & 39.48 \\
\hline$\delta^{18} \mathrm{O}$ of nitrate + nitrite $(\%)$ & 24 & -1.39 & 7.86 & 19.89 & 27 & 0.67 & 9.46 & 22.98 & 22 & 2.37 & 8.66 & 19.63 \\
\hline
\end{tabular}


Table 11. Statistical summary of water-quality properties and constituents by sampling period._Continued

[diss., dissolved; mg/L, milligrams per liter; <, less than; $\mu \mathrm{S} / \mathrm{cm}$, microsiemens per centimeter; ${ }^{\circ} \mathrm{C}$, degrees Celsius, $\mathrm{N}$, nitrogen; $\mathrm{P}$, phosphorus; O, oxygen; \% , per mil]

\begin{tabular}{|c|c|c|c|c|c|c|c|c|c|c|c|c|}
\hline \multirow{2}{*}{$\begin{array}{c}\text { Chemical } \\
\text { constituent or } \\
\text { property (unit) }\end{array}$} & \multicolumn{4}{|c|}{ December 2012} & \multicolumn{4}{|c|}{ February 2013} & \multicolumn{4}{|c|}{ April 2013} \\
\hline & $\begin{array}{l}\text { Number of } \\
\text { samples }\end{array}$ & Minimum & Median & Maximum & $\begin{array}{l}\text { Number of } \\
\text { samples }\end{array}$ & Minimum & Median & Maximum & $\begin{array}{l}\text { Number of } \\
\text { samples }\end{array}$ & Minimum & Median & Maximum \\
\hline \multicolumn{13}{|c|}{ Water-quality properties } \\
\hline Temperature, water $\left({ }^{\circ} \mathrm{C}\right)$ & 54 & 8.9 & 12.7 & 17.1 & 54 & 7.2 & 11.1 & 14.8 & 54 & 11.6 & 14.3 & 21.1 \\
\hline $\begin{array}{l}\text { Specific conductance } \\
\left(\mu \mathrm{S} / \mathrm{cm} \text { at } 25^{\circ} \mathrm{C}\right)\end{array}$ & 53 & 49 & 141 & 465 & 53 & 56 & 114 & 328 & 53 & 52 & 120 & 271 \\
\hline Oxygen, diss. (mg/L) & 54 & 0.01 & 2.1 & 7.4 & 54 & 1.9 & 8.0 & 10.5 & 54 & 0.02 & 5.0 & 10.1 \\
\hline $\mathrm{pH}$ (standard units) & 54 & 5.1 & 6.0 & 7.0 & 54 & 4.2 & 6.0 & 6.7 & 54 & 4.7 & 6.3 & 7.0 \\
\hline \multicolumn{13}{|c|}{ Major ions } \\
\hline Calcium, diss. (mg/L) & 53 & 1.92 & 8.58 & 37.8 & 53 & 2.01 & 6.37 & 18.2 & 53 & 1.73 & 6.99 & 21.4 \\
\hline Magnesium, diss. (mg/L) & 53 & 0.80 & 3.56 & 11.3 & 53 & 1.00 & 2.94 & 7.74 & 53 & 0.81 & 2.90 & 6.22 \\
\hline Sodium, diss. (mg/L) & 53 & 3.26 & 7.33 & 24.2 & 53 & 3.73 & 5.89 & 16.7 & 53 & 3.78 & 6.75 & 17.4 \\
\hline Potassium, diss. (mg/L) & 53 & 1.58 & 6.44 & 27.2 & 53 & 1.54 & 4.94 & 24.9 & 53 & 0.60 & 4.75 & 19.4 \\
\hline Chloride, diss. (mg/L) & 53 & 7.62 & 20.0 & 59.1 & 53 & 7.89 & 14.7 & 37.5 & 53 & 8.84 & 15.4 & 34.4 \\
\hline Sulfate, diss. (mg/L) & 53 & 0.21 & 3.53 & 46.7 & 53 & 2.43 & 10.8 & 28.6 & 53 & 0.31 & 4.37 & 15.7 \\
\hline \multicolumn{13}{|c|}{ Nutrients } \\
\hline $\begin{array}{l}\text { Ammonia }+ \text { organic } \mathrm{N} \text {, total } \\
(\mathrm{mg} / \mathrm{L} \text { as } \mathrm{N})\end{array}$ & 54 & 0.18 & 0.81 & 2.0 & 54 & 0.32 & 0.66 & 1.5 & 54 & 0.52 & 1.1 & 4.8 \\
\hline Ammonia, diss. (mg/L as $\mathrm{N})$ & 54 & $<0.010$ & 0.056 & 0.761 & 54 & $<0.010$ & 0.030 & 0.284 & 54 & $<0.010$ & 0.182 & 3.42 \\
\hline Total organic $\mathrm{N}$ (mg/L as $\mathrm{N})$ & 54 & 0.18 & 0.70 & 1.4 & 54 & 0.30 & 0.56 & 1.4 & 54 & 0.48 & 0.85 & 2.0 \\
\hline Nitrate + nitrite, diss. $(\mathrm{mg} / \mathrm{L}$ as $\mathrm{N})$ & 54 & $<0.040$ & $<0.040$ & 7.94 & 54 & $<0.040$ & 0.993 & 15.9 & 54 & $<0.040$ & 0.153 & 5.04 \\
\hline Total $\mathrm{N}(\mathrm{mg} / \mathrm{L}$ as $\mathrm{N})$ & 54 & 0.22 & 0.94 & 9.1 & 54 & 0.36 & 1.6 & 17.0 & 54 & 0.56 & 1.3 & 6.4 \\
\hline Orthophosphate, diss. (mg/L as P) & 54 & $<0.004$ & 0.034 & 0.713 & 54 & $<0.004$ & 0.009 & 0.052 & 54 & $<0.004$ & 0.034 & 0.347 \\
\hline Total P (mg/L as P) & 54 & 0.011 & 0.128 & 1.14 & 54 & 0.009 & 0.044 & 0.525 & 54 & 0.013 & 0.132 & 0.859 \\
\hline \multicolumn{13}{|c|}{ Isotopes } \\
\hline$\delta^{15} \mathrm{~N}$ of nitrate + nitrite $(\%)$ & 19 & 6.09 & 15.33 & 38.64 & 46 & 6.08 & 11.33 & 22.87 & 32 & 4.92 & 13.22 & 30.65 \\
\hline$\delta^{18} \mathrm{O}$ of nitrate + nitrite $(\%)$ & 19 & 5.36 & 8.60 & 21.33 & 46 & 5.18 & 9.31 & 14.01 & 32 & 3.46 & 8.87 & 16.60 \\
\hline
\end{tabular}



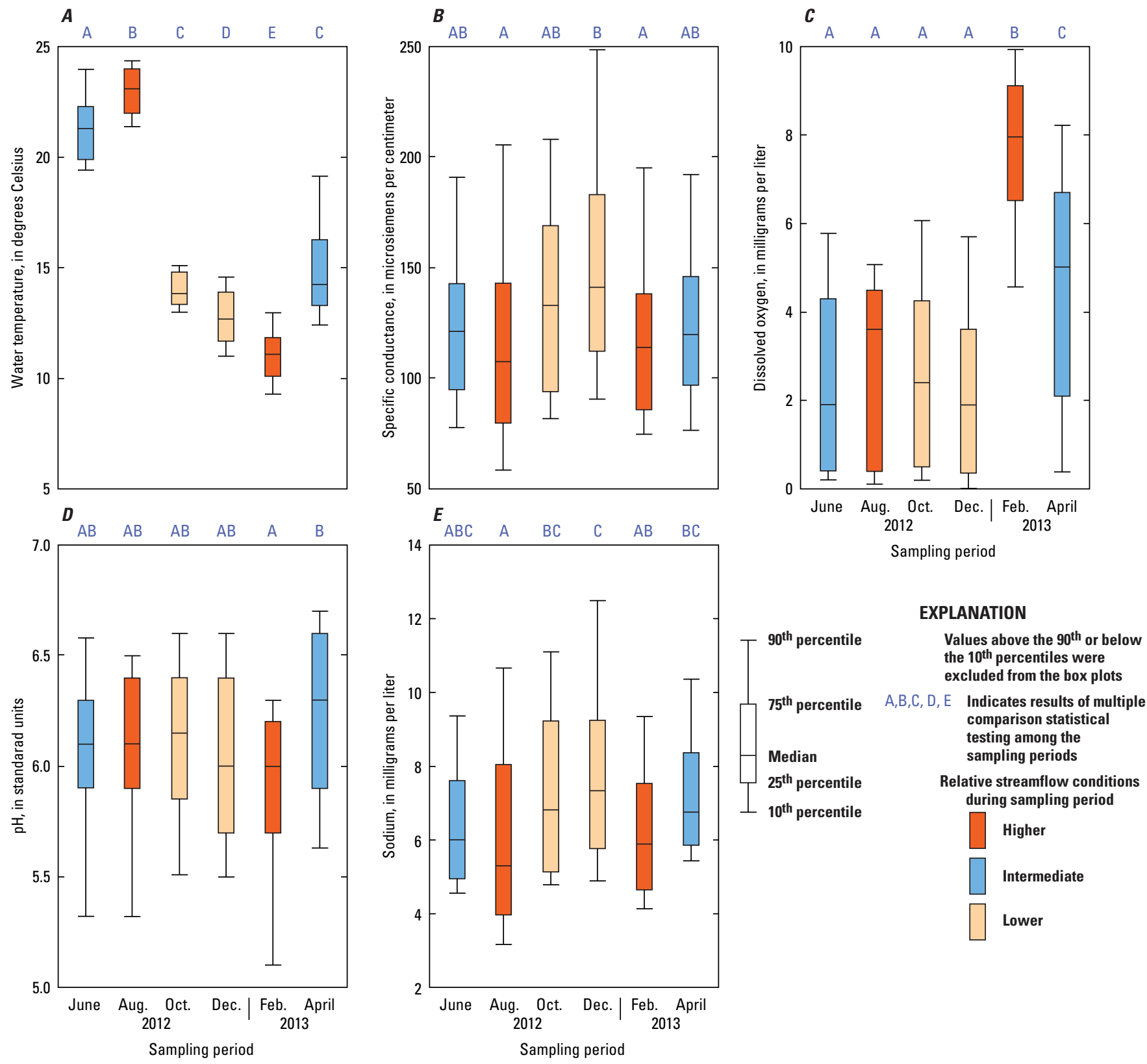

Figure 7. Distributions of $(A)$ temperature, $(B)$ specific conductance, $(C)$ dissolved oxygen, $(D) \mathrm{pH},(E)$ sodium, $(F)$ potassium, $(G)$ chloride, $(H)$ sulfate, $(/)$ ammonia plus organic nitrogen, $(J)$ ammonia, $(K)$ total organic nitrogen, $(L)$ nitrate plus nitrite,

$(M)$ total nitrogen, $(M)$ orthophosphate, and $(0)$ total phosphorus for all study sites based on sampling period (for a given constituent, if a sampling period contains the same letter above it as another sampling period, there is no statistical difference between them at the 95 percent confidence level). 

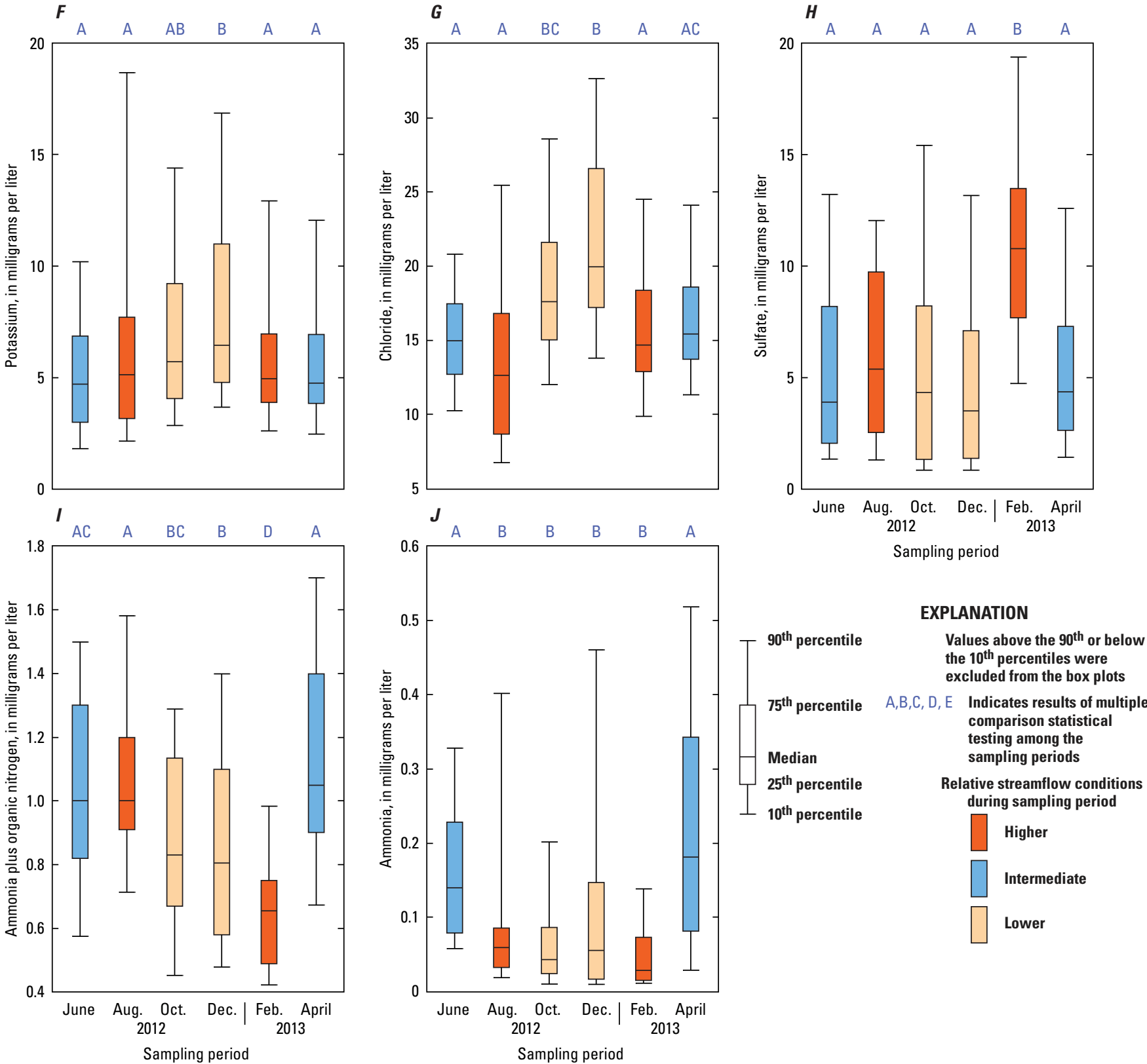

Figure 7. Distributions of $(A)$ temperature, $(B)$ specific conductance, $(C)$ dissolved oxygen, $(D) \mathrm{pH},(E)$ sodium, $(F)$ potassium, $(G)$ chloride, $(H)$ sulfate, $(I)$ ammonia plus organic nitrogen, $(J)$ ammonia, $(K)$ total organic nitrogen, $(L)$ nitrate plus nitrite, $(M)$ total nitrogen, $(M)$ orthophosphate, and $(O)$ total phosphorus for all study sites based on sampling period (for a given constituent, if a sampling period contains the same letter above it as another sampling period, there is no statistical difference between them at the 95 percent confidence level).-Continued 

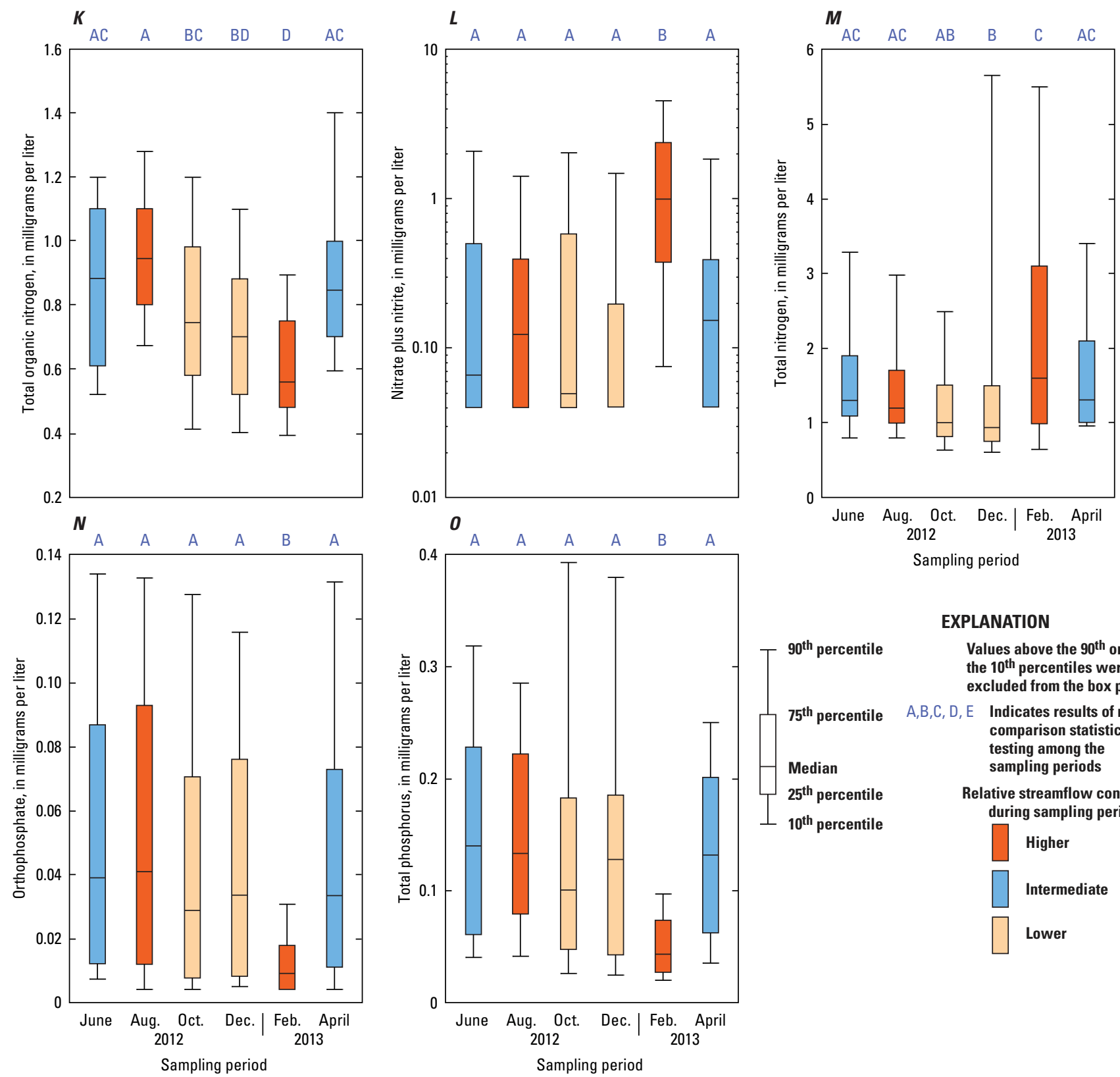

EXPLANATION

T $9^{\text {th }}$ percentile Values above the $90^{\text {th }}$ or below the $10^{\text {th }}$ percentiles were excluded from the box plots

$75^{\text {th }}$ percentile $A, B, C, D, E$ Indicates results of multiple comparison statistical testing among the sampling periods

Median

$25^{\text {th }}$ percentile

Relative streamflow conditions during sampling period

$10^{\text {th }}$ percentile

Higher

Intermediate

Lower

Figure 7. Distributions of $(A)$ temperature, $(B)$ specific conductance, $(C)$ dissolved oxygen, $(D) \mathrm{pH},(E)$ sodium, $(F)$ potassium, $(G)$ chloride, $(H)$ sulfate, $(/)$ ammonia plus organic nitrogen, $(J)$ ammonia, $(K)$ total organic nitrogen, $(L)$ nitrate plus nitrite,

$(M)$ total nitrogen, $(N)$ orthophosphate, and $(0)$ total phosphorus for all study sites based on sampling period (for a given constituent, if a sampling period contains the same letter above it as another sampling period, there is no statistical difference between them at the 95 percent confidence level)._- Continued 
including assimilation and release by algae and aquatic plants; microbially mediated reactions like denitrification; adsorption and desorption processes; and exchange between streambed sediment and the overlying water column (Mulholland, 1992; McMahon and Böhlke, 1996; Mulholland and Hill, 1997; Mainstone and Parr, 2002; Dunne and Reddy, 2005). Interestingly, geochemically reducing conditions present in the buffer and hyporheic zones that help mitigate the amount of nitrate in groundwater discharged to the streams are the same conditions that can promote the mobilization and release of sorbed P from streambed deposits, including sediment derived from upland areas and decaying organic matter, into overlying stream water (Spruill, 2000; Spruill and others, 2005).

The results for nitrate+nitrite (fig. $7 L$ ) were notably different than the results for ammonia (fig. $7 J$ ) and organic $\mathrm{N}$ (fig. $7 K$ ). Nitrate+nitrite concentrations were substantially influenced by microbial denitrification, a process that reduces nitrate during anaerobic decomposition of organic matter. The median nitrate+nitrite concentration of $0.993 \mathrm{mg} / \mathrm{L}$ observed for February was substantially higher than the median concentrations for the other sampling periods, which ranged from $<0.040$ to $0.153 \mathrm{mg} / \mathrm{L}$ (table 11). The higher nitrate+nitrite concentrations for February coincided with higher streamflows and DO concentrations, and thus appear to reflect more overland contributions of nitrate in water from upstream fielddrainage ditches to the streams, as well as less denitrification, for that period. These conditions are most likely to occur in the winter when the water table is high and the nitrate that is contributed to field ditches (from runoff, lateral groundwater inflows, and tile drainage) is likely to bypass the otherwise anoxic zones in near stream areas. Nitrate in the field ditches is rapidly carried to the main stem of the streams during high flows and is subject to less instream processing, including denitrification and uptake by plants and algae, when stream water temperatures are cold (fig. $7 A$ ) and DO concentrations are elevated (fig. $7 \mathrm{C}$ ), as noted for the February sampling period. The lower nitrate+nitrite concentrations that occurred under the more reduced DO conditions during the June, August, October, and December sampling periods reflect a higher amount of denitrification. The highest median total $\mathrm{N}$ concentration of $1.6 \mathrm{mg} / \mathrm{L}$ also was observed for February (fig. 7M), reflecting the larger contribution from nitrate+nitrite compared to organic $\mathrm{N}$, which constituted the more dominant fraction of total $\mathrm{N}$ among the other sampling periods.

Interestingly, sulfate (fig. $7 \mathrm{H}$ ) had a similar distribution among the sampling periods as did both $\mathrm{DO}$ (fig. $7 \mathrm{C}$ ) and nitrate+nitrite (fig. $7 L$ ). Sulfate concentrations were significantly higher during the February period. During the other periods with lower DO concentrations, sulfate apparently was reduced to other forms of sulfur.

In contrast to nitrate + nitrite, the median concentrations of ammonia $(0.030 \mathrm{mg} / \mathrm{L})$ and total organic $\mathrm{N}(0.56 \mathrm{mg} / \mathrm{L})$ were lowest for the February period (fig. $7 J, K$; table 11). Similar to the seasonal pattern observed for water temperature (fig. 7A), median organic $\mathrm{N}$ concentrations were highest during the warm, growing-season months (June, August, and April) and steadily decreased through the fall and winter periods (October, December, and February). Organic N in streams occurs in both the dissolved form, such as urea, amino acids, and humic substances, and the particulate form, such as phytoplankton, zooplankton, microorganisms, and organic detritus. In this study, the dissolved organic $\mathrm{N}$ fraction was not measured. Therefore, the extent to which dissolved or particulate substances contributed to the organic nitrogen pool is not known. The observed pattern for total organic $\mathrm{N}$ is possibly influenced by algal and aquatic plant production, which likely would be higher during spring and summer and lower during the more dormant winter months.

Interesting differences among sampling periods also were noted for ortho-P (fig. $7 N$ ) and total P (fig. 7O). Overall concentrations for ortho-P (median of $0.009 \mathrm{mg} / \mathrm{L}$ ) and total $\mathrm{P}$ (median $0.044 \mathrm{mg} / \mathrm{L}$ ) were lowest in the February sampling period, the same period when the highest concentrations of nitrate+nitrite (fig. $7 L$ ) observed in the streams were attributed to increased overland transport of water through upstream field-drainage ditches. Concentrations of ortho-P and total $\mathrm{P}$ during the August period with higher flow conditions were not significantly different from the intermediate- or lower-flow sampling periods. In free-flowing streams with no point-source inputs, higher $\mathrm{P}$ concentrations in surface water tend to occur during higher streamflows in association with increased sediment inputs from overland runoff. In contrast, $P$ patterns observed at the swampy, sluggish streams in this study area suggest that instream processes play a dominant role in $\mathrm{P}$ cycling. These processes may include adsorption/ desorption processes and assimilation by aquatic plants, algae, and microbes in both the bed material and water column (Mainstone and Parr, 2002; Dunne and Reddy, 2005). The higher $\mathrm{P}$ concentrations observed during the more reduced DO conditions for the June, August, October, December, and April sampling periods possibly reflect higher amounts of algal biomass and (or) P releases into the water column from microbial degradation of organic matter and (or) desorption from organic substrates or anoxic bed sediments.

In summary, seasonal and hydrologic factors influenced water quality in these Coastal Plain agricultural watersheds. The differences noted among the sampling periods indicate that the interactions between seasonal climatic differences, streamflow conditions, and instream biotic and abiotic processes are complex and their integrated effects can have varying degrees of influence on individual nutrients. These findings are important to consider when developing studies to assess stream nutrient conditions in similar Coastal Plain settings and can inform the choice of specific objectives, nutrients to be examined, and overall timeline and frequency of sampling needed to capture seasonal and (or) hydrologic variability in the data. 


\section{Water-Quality Differences Related to Watershed Land-Use Type}

Many of the water-quality properties and constituents were significantly influenced (ANOVA $\mathrm{P}<0.05$ ) by watershed land-use type (table 10) on the basis of the results for all six sampling periods. Water-quality differences among the three land-use types, or groups (18 BK sites, $18 \mathrm{SW}$ sites, and 18 SP sites), were examined to better understand potential CAFO influences. Statistical summaries, by land-use group, of the original (non-ranked transformed) water-quality data are provided in tabular (table 12) and graphical formats (fig. 8) to aid the discussion. Figure 8 includes box plots for properties and constituents with significant differences (ANOVA $\mathrm{P}<0.05$ ) among land-use groups; results of the multiple-comparison tests among the groups are denoted along the top of the plots. No significant differences in water temperature, DO, calcium, total organic $\mathrm{N}$, ortho-P, total $\mathrm{P}$, and $\delta^{18} \mathrm{O}$ of nitrate+nitrite were noted among the land-use types.

Significant differences were noted in specific conductance, $\mathrm{pH}$, and all of the major ions, except calcium, among the land-use groups (table 10). Specific conductance, $\mathrm{pH}$, magnesium, sodium, potassium, and chloride were significantly different between the BK and SW sites and the BK and SP sites, but not between the SW and SP sites (fig. $8 A-F$ ). Median specific conductance values for the SW and SP sites were higher than the BK sites, which reflects the higher median concentrations of dissolved magnesium, sodium, potassium, and chloride also noted at the SW and SP sites. Median $\mathrm{pH}$ values also were higher for the SW and SP sites relative to the BK sites. Sulfate (fig. $8 G$ ) for the SP sites was significantly different than both the BK and SW sites.

Median concentrations of ammonia + organic N, ammonia, and total $\mathrm{N}$ were higher at the SW and SP sites than at the BK sites (fig. $8 H, I$, and $K$; table 12 ). No significant difference in total organic $\mathrm{N}$ was noted among the land-use groups, suggesting that the differences in ammonia+organic $\mathrm{N}$ between the BK and SW sites and the BK and SP sites are associated with the ammonia fraction. Nitrate+nitrite was the only constituent found to be significantly different between all three land-use groups (fig. 8J). Median nitrate+nitrite concentrations progressively increase from the BK to the SW to the SP sites. Interestingly, no significant differences were identified for the $\mathrm{P}$ nutrients (ortho-P or total $\mathrm{P}$ ) on the basis of land-use type (table 10).
Similar to the $\mathrm{N}$ constituents, median $\delta^{15} \mathrm{~N}$ values of nitrate+nitrite for the SW and SP sites were higher, or more positive, than the BK sites (fig. $8 L$ ), indicating that nitrate+nitrite at the SW and SP sites was more enriched in $15 \mathrm{~N}$. The higher median $\delta^{15} \mathrm{~N}$ values of nitrate+nitrite likely indicate that $\mathrm{N}$ inputs to streams at the SW and SP sites were more influenced by animal-manure sources; however, it is important to note that other processes, such as denitrification and assimilation by algae, also may have influenced the observed $\delta^{15} \mathrm{~N}$ values of nitrate+nitrite.

These results indicate that waste-manure storage and (or) field applications at the CAFOs have increased surface-water concentrations of selected constituents at the SW and SP sites above those noted for the BK sites, which do not contain any active CAFOs. Although the various types and amounts of commercial fertilizer products used in the watersheds of the individual study sites are unknown, it is considered unlikely that the significant differences noted in the water-quality constituents would only occur between the BK group of sites and both CAFO site groups (SW and SP) and not between the SW and SP site groups if related solely to differences in commercial fertilizer use. Most of the statistically significant differences for major ions (magnesium, sodium, potassium, and chloride) and nutrients (ammonia+organic N, ammonia, nitrate+nitrite, and total $\mathrm{N}$ ) occurred between the BK and SW sites and the BK and SP sites (fig. 8). The median concentrations of these constituents were all higher at the SW and SP sites relative to the BK sites.

It is unclear whether the lack of detectable differences in $\mathrm{P}$ among the land-use groups indicates that stream inputs of $\mathrm{P}$ were the same among the study watersheds with and without animal-waste manure applications or whether other environmental processes (like sediment deposition, adsorption/ desorption, and assimilation) have obscured differences in source inputs of $\mathrm{P}$ derived from commercial fertilizer and (or) animal-waste manure.

Phosphorus, which is relatively immobile in soil, typically is transported to streams in particulate form during overland runoff. The more soluble $\mathrm{N}$ constituents, such as ammonia and nitrate+nitrite, are prone to leaching in soils and may be transported to streams through both groundwater discharge and overland runoff. The disparity between $\mathrm{N}$ and $\mathrm{P}$ response among the sites may reflect differences in transport pathways or instream processing that influenced instream concentrations of these two classes of nutrients. 
Table 12. Statistical summary of water-quality properties and constituents by land-use type.

[diss., dissolved; $\mathrm{mg} / \mathrm{L}$, milligrams per liter; $\%$, percent; $\mu \mathrm{S} / \mathrm{cm}$, microsiemens per centimeter; ${ }^{\circ} \mathrm{C}$, degrees Celsius, $\mathrm{N}$, nitrogen; $\mathrm{P}$, phosphorus; $\mathrm{O}$, oxygen; $\delta$, delta; $<$, less than; $\%$, per mil]

\begin{tabular}{|c|c|c|c|c|c|c|c|c|c|c|c|c|}
\hline \multirow{2}{*}{$\begin{array}{l}\text { Chemical property } \\
\text { or constituent (unit) }\end{array}$} & \multicolumn{4}{|c|}{ Background (BK) sites } & \multicolumn{4}{|c|}{ Swine (SW) sites } & \multicolumn{4}{|c|}{ Swine and poultry (SP) sites } \\
\hline & $\begin{array}{l}\text { Number of } \\
\text { samples }\end{array}$ & Minimum & Median & Maximum & $\begin{array}{l}\text { Number of } \\
\text { samples }\end{array}$ & Minimum & Median & Maximum & $\begin{array}{c}\text { Number of } \\
\text { samples }\end{array}$ & Minimum & Median & Maximum \\
\hline \multicolumn{13}{|c|}{ Water-quality properties } \\
\hline Temperature, water $\left({ }^{\circ} \mathrm{C}\right)$ & 106 & 7.2 & 14.7 & 27.3 & 108 & 8.0 & 14.2 & 26.2 & 106 & 8.0 & 14.6 & 24.4 \\
\hline Specific conductance $\left(\mu \mathrm{S} / \mathrm{cm}\right.$ at $\left.25^{\circ} \mathrm{C}\right)$ & 106 & 49 & 98 & 264 & 102 & 48 & 132 & 328 & 106 & 50 & 138 & 440 \\
\hline Oxygen, diss. (mg/L) & 106 & 0.01 & 3.2 & 10.4 & 108 & 0.01 & 3.4 & 10.1 & 106 & 0.01 & 4.3 & 10.5 \\
\hline pH (standard units) & 105 & 4.2 & 6.0 & 6.8 & 108 & 4.7 & 6.2 & 6.9 & 106 & 4.3 & 6.2 & 7.2 \\
\hline \multicolumn{13}{|c|}{ Major ions } \\
\hline Calcium, diss. (mg/L) & 106 & 1.73 & 6.92 & 15.9 & 102 & 1.94 & 8.52 & 19.7 & 106 & 2.34 & 7.16 & 43.9 \\
\hline Magnesium, diss. (mg/L) & 106 & 1.45 & 2.64 & 4.61 & 102 & 0.76 & 3.34 & 7.74 & 106 & 0.92 & 3.76 & 11.3 \\
\hline Sodium, diss. (mg/L) & 106 & 2.17 & 5.41 & 24.2 & 102 & 3.67 & 6.90 & 16.0 & 106 & 3.15 & 6.80 & 36.0 \\
\hline Potassium, diss. (mg/L) & 106 & 0.60 & 3.90 & 15.6 & 102 & 0.90 & 6.84 & 24.9 & 106 & 1.41 & 6.58 & 46.2 \\
\hline Chloride, diss. (mg/L) & 106 & 5.06 & 14.0 & 53.2 & 102 & 7.84 & 17.3 & 37.7 & 106 & 6.01 & 17.1 & 65.3 \\
\hline Sulfate, diss. (mg/L) & 106 & 0.14 & 3.84 & 46.7 & 102 & 0.14 & 5.14 & 28.6 & 106 & 0.64 & 6.92 & 28.4 \\
\hline \multicolumn{13}{|c|}{ Nutrients } \\
\hline Ammonia + organic $\mathrm{N}$, total $(\mathrm{mg} / \mathrm{L}$ as $\mathrm{N})$ & 106 & 0.36 & 0.83 & 2.3 & 108 & 0.32 & 0.94 & 4.8 & 106 & 0.16 & 0.96 & 7.4 \\
\hline Ammonia, diss. (mg/L as N) & 106 & $<0.010$ & 0.048 & 0.932 & 108 & $<0.010$ & 0.102 & 3.42 & 106 & $<0.010$ & 0.072 & 4.7 \\
\hline Total organic $\mathrm{N}$ (mg/L as $\mathrm{N})$ & 106 & 0.23 & 0.76 & 1.7 & 108 & 0.27 & 0.82 & 2.0 & 106 & 0.12 & 0.80 & 2.7 \\
\hline Nitrate + nitrite, diss. $(\mathrm{mg} / \mathrm{L}$ as $\mathrm{N})$ & 106 & $<0.040$ & 0.048 & 1.51 & 108 & $<0.04$ & 0.173 & 15.9 & 106 & $<0.040$ & 0.352 & 10.8 \\
\hline Total N (mg/L as N) & 106 & 0.42 & 1.0 & 2.3 & 108 & 0.36 & 1.5 & 17.0 & 106 & 0.20 & 1.3 & 14.0 \\
\hline Ortho-phosphate, diss. (mg/L as $\mathrm{P}$ ) & 106 & $<0.004$ & 0.026 & 0.713 & 108 & $<0.004$ & 0.030 & 0.534 & 106 & $<0.004$ & 0.026 & 0.466 \\
\hline Total P (mg/L as P) & 106 & 0.015 & 0.098 & 1.14 & 108 & 0.009 & 0.122 & 0.981 & 106 & 0.012 & 0.100 & 0.860 \\
\hline \multicolumn{13}{|c|}{ Isotopes } \\
\hline$\delta^{15} \mathrm{~N}$ of nitrate + nitrite $(\%)$ & 40 & 4.92 & 9.39 & 16.99 & 61 & 5.66 & 13.57 & 48.88 & 69 & 6.52 & 15.33 & 39.97 \\
\hline$\delta^{18} \mathrm{O}$ of nitrate + nitrite $(\%)$ & 40 & 5.18 & 9.43 & 16.27 & 61 & -1.39 & 8.48 & 22.98 & 69 & 0.29 & 9.04 & 21.33 \\
\hline
\end{tabular}



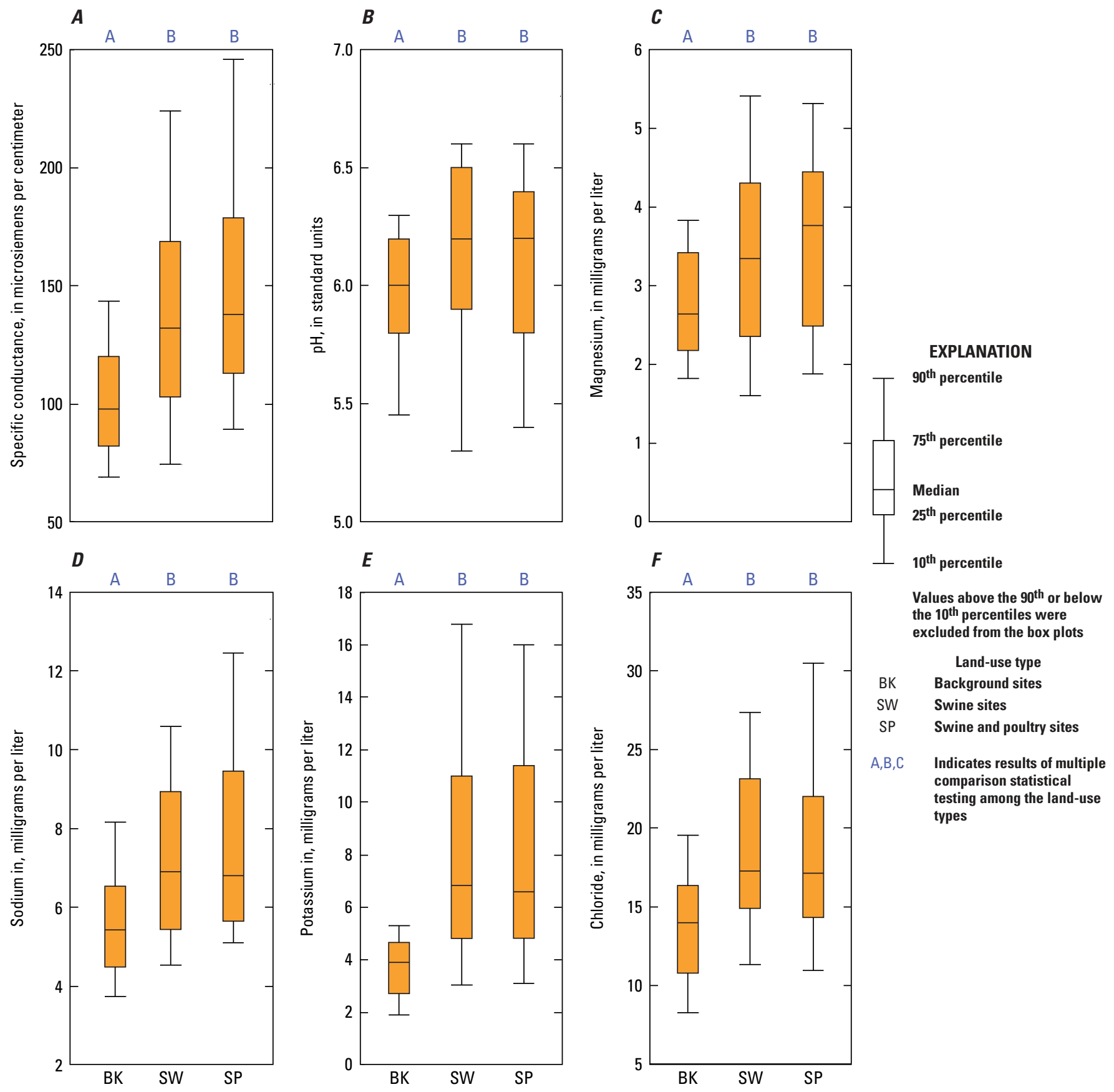

Figure 8. Distributions of $(A)$ specific conductance, $(B) \mathrm{pH},(C)$ magnesium, $(D)$ sodium, $(E)$ potassium, $(F)$ chloride, $(G)$ sulfate, $(H)$ ammonia plus organic nitrogen, $(/)$ ammonia, $(J)$ nitrate plus nitrite, $(K)$ total nitrogen, and $(L)$ delta nitrogen-15 of nitrate plus nitrite for all sampling periods based on watershed land-use type (for a given constituent, if a land-use type contains the same letter above it as another land-use type, there is no statistical difference between them at the 95 percent confidence level). 

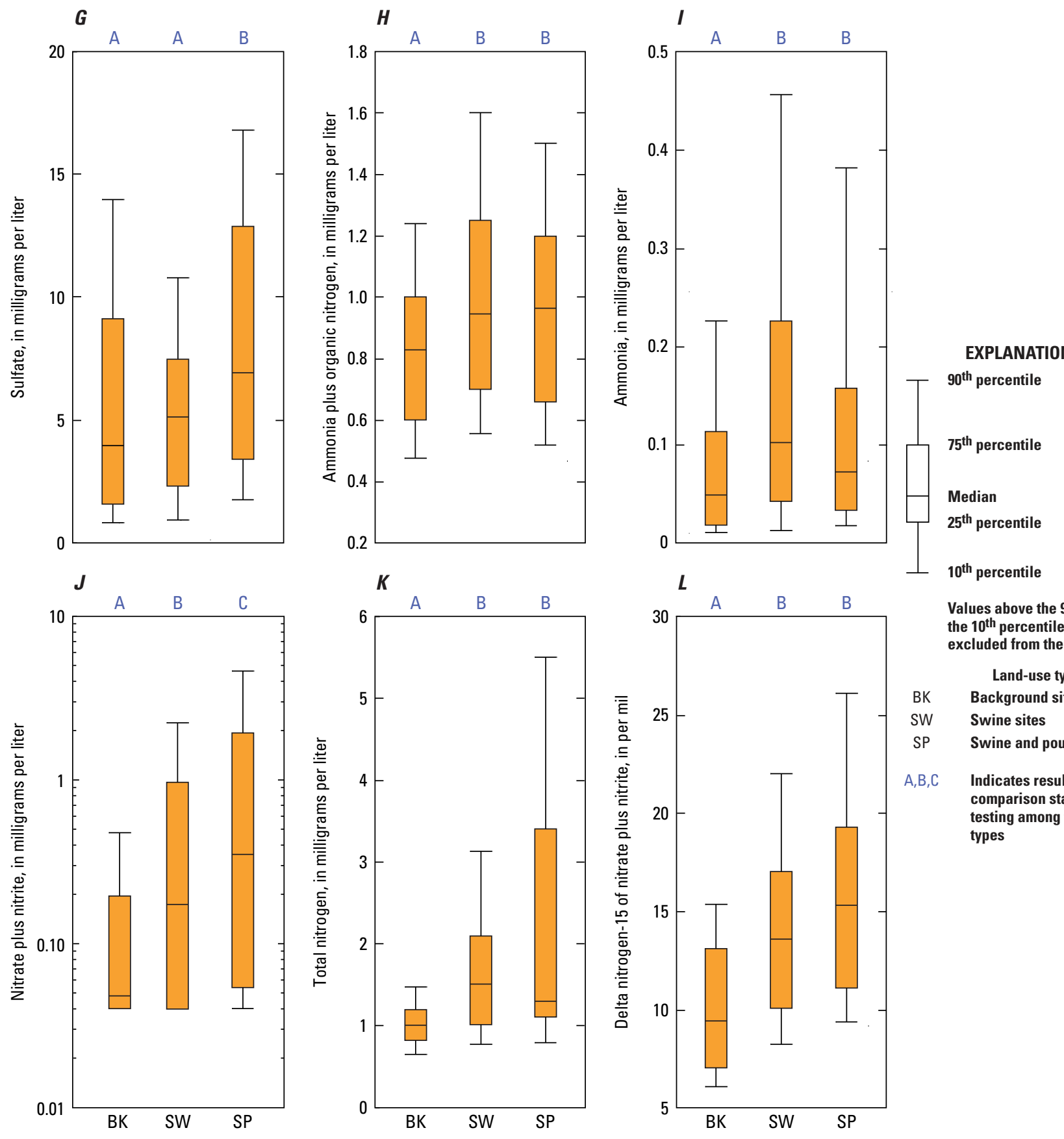

Values above the $90^{\text {th }}$ or below the $10^{\text {th }}$ percentiles were excluded from the box plots

Land-use type Background sites Swine sites Swine and poultry sites

Indicates results of multiple comparison statistical testing among the land-use types

Figure 8. Distributions of $(A)$ specific conductance, $(B) \mathrm{pH},(C)$ magnesium, $(D)$ sodium, $(E)$ potassium, $(F)$ chloride, $(G)$ sulfate, $(H)$ ammonia plus organic nitrogen, $(/)$ ammonia, $(J)$ nitrate plus nitrite, $(K)$ total nitrogen, and $(L)$ delta nitrogen-15 of nitrate plus nitrite for all sampling periods based on watershed land-use type (for a given constituent, if a land-use type contains the same letter above it as another land-use type, there is no statistical difference between them at the 95 percent confidence level)—Continued 


\section{Multi-Analyte Approach for Differentiating Sites With Water- Quality Effects From CAFOs}

The statistical evaluations discussed previously indicated that when all 54 primary study sites were examined collectively on the basis of their land-use type (BK, SW, and $\mathrm{SP})$, several water-quality differences related to animal-waste manures were identified for the SW and SP site groups. Interestingly, some individual SW and SP sites did not appear to be affected by animal-waste manures. Data were further evaluated to better understand distinctions among selected water-quality constituents at sites with and without CAFOs to aid identification of those SW and SP watersheds with measurable CAFO manure effects on water quality.

\section{Insights Based on Multi-Site Reconnaissance Sampling Within Selected Watersheds During April 2013}

During April 2013, samples were collected once at 23 secondary sites within 9 of the primary watersheds to obtain water-quality data from upstream reaches. These secondary sites were located in proximity to either swine CAFOs and spray fields or to background agricultural fields. Nutrient and ion concentrations and the nitrate + nitrite stable isotope data were evaluated to distinguish sites where CAFO waste manures did or did not have a measurable effect on surfacewater quality.

Stable isotopes $\left(\delta^{15} \mathrm{~N}\right.$ and $\left.\delta^{18} \mathrm{O}\right)$ of nitrate are often used in water-quality studies as environmental tracers for investigating anthropogenic sources of nitrogen (such as atmospheric deposition, commercial inorganic fertilizers, and organic animal manures and septic wastes). Kendall and others (2007) diagrammed common ranges, or fields, of nitrate $\delta^{15} \mathrm{~N}$ and $\delta^{18} \mathrm{O}$ values derived or nitrified from various $\mathrm{N}$ sources (fig. 9). The $\delta^{18} \mathrm{O}$ values tend to be more useful for separating nitrate derived from atmospheric deposition or synthetic nitrate fertilizers from other sources. The $\delta^{15} \mathrm{~N}$ values tend to be more useful for distinguishing nitrate derived from microbial nitrification of ammonium and (or) organic $\mathrm{N}$ in fertilizer, precipitation, soil, and animal manure or human septic waste because these sources have overlapping $\delta^{18} \mathrm{O}$ values, commonly between -10 and $+15 \%$ (Kendall and others, 2007; Xue and others, 2009).

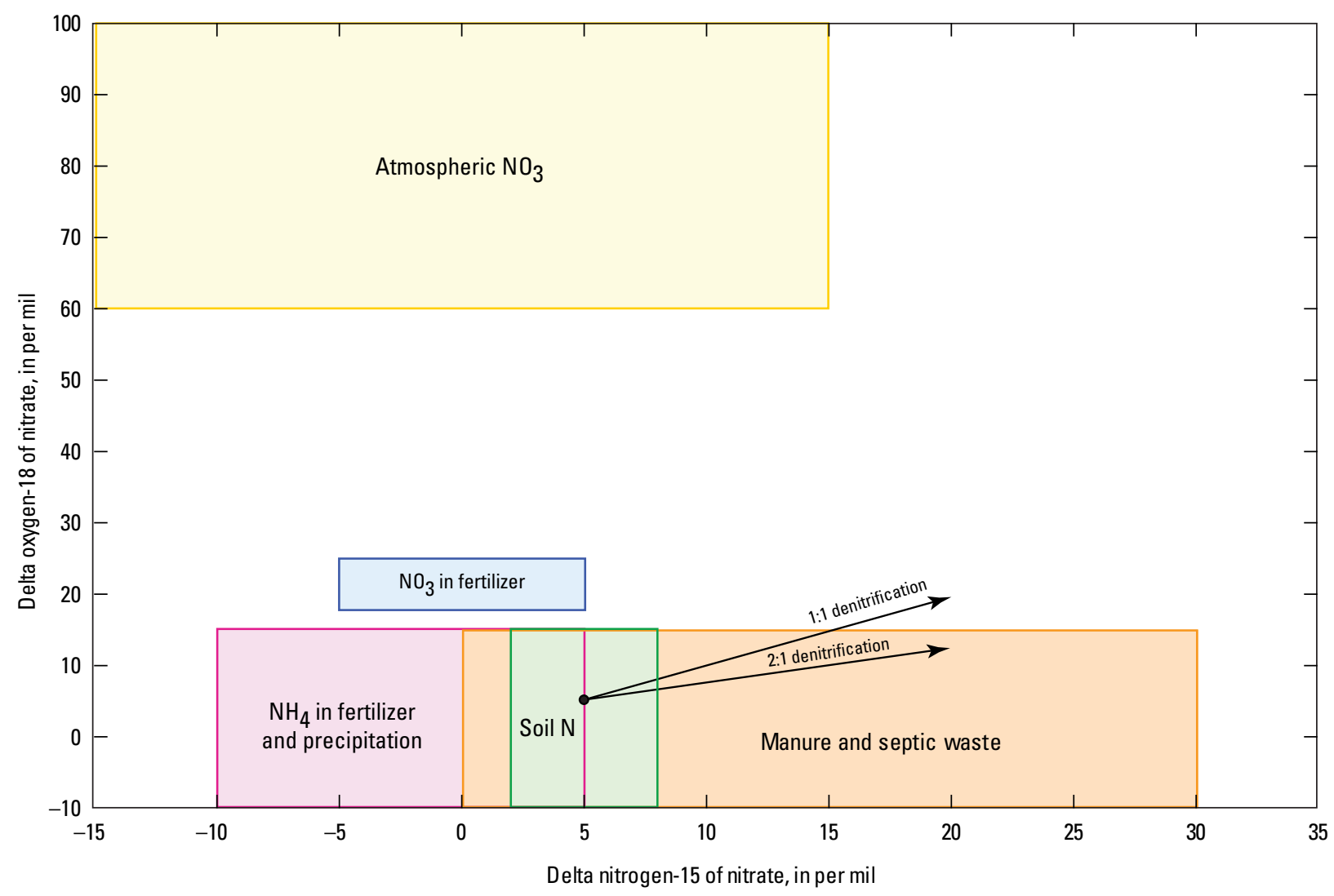

Figure 9. Common ranges in values of delta nitrogen-15 and delta oxygen-18 of nitrate derived from various nitrogen sources (modified from Kendall and others, 2007). 
Inorganic fertilizers and animal-waste manures, which are the main sources of $\mathrm{N}$ in the agricultural watersheds in this study, generally have distinct $\delta^{15} \mathrm{~N}$ nitrate values (Kendall, 1998). The $\delta^{15} \mathrm{~N}$ values of nitrate originating from inorganic fertilizers typically are lower, about -5 to $+5 \%$, than those from animal manures, which typically are higher and have a wider range of compositions, about 0 to $+30 \%$ (Fogg and others, 1998; Kendall and others, 2007; Xue and others, 2009). Note that nitrate derived from human septic wastes generally has $\delta^{15} \mathrm{~N}$ values of about +5 to $+20 \%$ that are indistinguishable from animal manures (Fogg and others, 1998; Xue and others, 2009); however, human-derived wastes are not considered to be a substantial contributor of $\mathrm{N}$ to streams in the study watersheds. Although the $\delta^{15} \mathrm{~N}$ values of soil nitrate derived from inorganic fertilizers tend to overlap those derived from the mineralization of natural soil organic $\mathrm{N}$, about 0 to $+8 \%$, they are often distinguishable from the higher nitrate $\delta^{15} \mathrm{~N}$ values associated with animal-waste manures (Fogg and others, 1998; Kendall and others, 2007; Xue and others, 2009).

Comparing measured nitrate $\delta^{15} \mathrm{~N}$ and $\delta^{18} \mathrm{O}$ values in samples against the general source boxes depicted in figure 9 may be useful for assessing potential sources if the original source signal of the nitrate has not been substantially altered. Complications arise if the isotopic composition reflects a mixture of two or more nitrate sources and (or) has been influenced by biogeochemical processes, such as assimilation or denitrification, that transform $\mathrm{N}$, which can cause the altered $\delta^{15} \mathrm{~N}$ and $\delta^{18} \mathrm{O}$ values to resemble those of other sources (Kendall and others, 2007). During the process of denitrification, microbes preferentially use the lighter ${ }^{14} \mathrm{~N}$ and ${ }^{16} \mathrm{O}$ isotopes, which enrich the remaining or residual nitrate pool with the heavier ${ }^{15} \mathrm{~N}$ and ${ }^{18} \mathrm{O}$ isotopes, resulting in more positive nitrate $\delta^{15} \mathrm{~N}$ and $\delta^{18} \mathrm{O}$ values. Denitrification causes coupled increases in the $\delta^{15} \mathrm{~N}$ and $\delta^{18} \mathrm{O}$ values of the residual nitrate by an approximate 1:1 to 2:1 ratio (Böttcher and others, 1990; Kendall and others, 2007).

The effects of denitrification are illustrated using an example of assumed nitrate having an initial $\delta^{15} \mathrm{~N}$ value of $5 \%$ and $\delta^{18} \mathrm{O}$ value of $5 \%$ similar to that derived from ammonium fertilizer or soil organic $\mathrm{N}$ (fig. 9). The two arrows indicate how the process of denitrification for nitrate with this initial isotopic signature produces residual nitrate $\delta^{15} \mathrm{~N}$ to $\delta^{18} \mathrm{O}$ values that progressively increase along either a $1: 1$ denitrification line (having a slope of 1) or 2:1 denitrification line (having a slope of 0.5 ). As the $\delta^{15} \mathrm{~N}$ and $\delta^{18} \mathrm{O}$ values of the initial nitrate reflecting an ammonium fertilizer or soil organic $\mathrm{N}$ source become increasingly more positive during denitrification, they become more similar to those expected for nitrate derived from animal-waste manures, thereby confounding interpretations of the nitrate sources.

These types of issues can make it complicated or impractical to identify nitrate sources solely on the basis of the nitrate isotopic compositions. It is beneficial to examine other chemical constituents in combination with the nitrate stable isotope data for differentiating sources of nitrate contamination in water (Spruill and others, 2002; Kendall and others,
2007; Xue and others, 2009). In the North Carolina Coastal Plain, Karr and others (2001) and Spruill and others (2002) used $\delta^{15} \mathrm{~N}$ data in combination with major ion data to examine sources of nitrate in groundwater. Karr and others (2001) used $\delta^{15} \mathrm{~N}$, potassium, and chloride data to examine swine-manure contamination in groundwater from a waste lagoon and spray field. Spruill and others (2002) evaluated the results of nitrate $\delta^{15} \mathrm{~N}$, nutrients (nitrate and ammonia) and major ions (calcium, magnesium, sodium, and potassium) with classification tree models to identify sources of groundwater nitrate derived from inorganic fertilizers, swine manure, poultry litter, and septicsystem wastes. Ratios of selected ion concentrations (calcium to magnesium and sodium to potassium) and summed concentrations of sodium+potassium were found to be useful indicators for distinguishing the different nitrate sources.

The examination of the April 2013 water-quality data for the primary and secondary study sites primarily focused on evaluating nitrate + nitrite and sodium + potassium concentrations in combination with the nitrate + nitrite $\delta^{15} \mathrm{~N}$ values for differentiating those sites with measurable effects of CAFO manure on water quality (table 13). Comments on whether the surface-water samples that were collected had the potential to be influenced by one or more CAFOs upstream from the sites are noted in table 13. Detailed evaluations of the data for each group of associated sites are provided separately as appendix A5. Insights based on the evaluations of the April 2013 dataset (appendix A5) are discussed below.

In six of the nine watersheds that were examined, measured effects of swine CAFO manure on surface water at one or more upstream secondary sites also were noted further downstream at the primary site locations (table 13). The extent to which influences of CAFO manure may be identified in surface water at downstream watershed locations likely varies depending on the particular watershed setting, including such things as basin size, density of CAFOs and their locations, the presence or absence of tile drains and field ditches, stream morphology, and streamflow conditions. Many of the secondary sites that were located next to or downstream from swine CAFOs were found to be influenced by swine manure in terms of nitrate+nitrite and sodium+potassium concentrations and nitrate + nitrite $\delta^{15} \mathrm{~N}$ values. Conversely, no water-quality effect was noted at some of the sites (table 13), which suggests that all CAFOs do not necessarily have a measurable effect on these water-quality constituents in adjacent sections of streams.

The combined use of the nitrate+nitrite, sodium+potassium, and $\delta^{15} \mathrm{~N}$ of nitrate+nitrite data proved valuable for identifying those 9 primary and 23 secondary sites either having or not having a measurable water-quality effect associated with CAFO waste manures (appendix A5). Of the 32 sites, 18 had measurable manure influence, 11 had no measurable manure influence (including the 4 background agricultural sites), and 3 had unclear results (table 13). Distinctions among the results are illustrated in figure 10 for the sites with, without, or unclear CAFO manure influences. Boundaries delineating the general distribution in the 
Table 13. Water-quality results for the April 2013 sample period used to examine waste-manure influences at the primary and secondary study sites.

[CAFO, concentrated animal feeding operation; mg/L, milligram per liter; $\delta^{15} \mathrm{~N}$, delta nitrogen-15; \%o, per mil; <, less than; na, not analyzed]

\begin{tabular}{|c|c|c|c|c|c|c|c|}
\hline $\begin{array}{l}\text { Study site } \\
\text { (site maps in } \\
\text { appendix A1) }\end{array}$ & $\begin{array}{c}\text { Potential to be } \\
\text { influenced by } \\
\text { CAFOs }\end{array}$ & $\begin{array}{l}\text { Dissolved } \\
\text { oxygen } \\
\text { (mg/L) }\end{array}$ & $\begin{array}{c}\text { Nitrate + } \\
\text { nitrite (mg/L) }\end{array}$ & $\begin{array}{c}\text { Sodium + } \\
\text { potassium } \\
\text { (mg/L) }\end{array}$ & $\begin{array}{c}\delta^{15} \mathrm{~N} \text { of nitrate } \\
+ \text { nitrite }(\% 0)\end{array}$ & $\begin{array}{c}\delta^{18} 0 \text { of nitrate } \\
+ \text { nitrite }(\% \circ)\end{array}$ & $\begin{array}{l}\text { Are the results interpreted to } \\
\text { reflect CAFO waste manure } \\
\text { influences at the site? } \\
\text { (see appendix A5) }\end{array}$ \\
\hline SW-04A & $\begin{array}{l}\text { Yes, near } \\
\text { upgradient edge of } \\
\text { swine spray field }\end{array}$ & 6.3 & 0.307 & 7.96 & 15.80 & 11.09 & Unclear \\
\hline SW-04B & Yes, 1 swine CAFO & 7.4 & 3.31 & 16.10 & 19.37 & 10.34 & Yes \\
\hline SW-04 & Yes, 1 swine CAFO & 3.4 & 1.09 & 16.66 & 22.16 & 10.62 & Yes \\
\hline SW-05A & Yes, 1 swine CAFO & 0.08 & 0.052 & 10.01 & na & na & No \\
\hline SW-05B & $\begin{array}{l}\text { No, background } \\
\text { agricultural fields }\end{array}$ & 4.2 & 1.70 & 7.28 & 9.66 & 8.43 & No \\
\hline SW-05C & Yes, 1 swine CAFO & 5.4 & 3.40 & 19.16 & 21.68 & 10.78 & Yes \\
\hline SW-05 & Yes, 4 swine CAFOs & 2.9 & 0.795 & 12.42 & 17.05 & 8.87 & Yes \\
\hline SW-08A & $\begin{array}{l}\text { Yes, } 5 \text { active and } 1 \\
\text { inactive swine CAFOs }\end{array}$ & 0.1 & $<0.040$ & 16.41 & na & na & Unclear \\
\hline SW-08B & Yes, 1 swine CAFO & 0.8 & 0.681 & 12.67 & 7.42 & 7.89 & No \\
\hline SW-08C & Yes, 3 swine CAFOs & 4.0 & 1.22 & 16.40 & 24.56 & 10.05 & Yes \\
\hline SW-08D & $\begin{array}{l}\text { No, background } \\
\text { agricultural fields }\end{array}$ & 6.3 & 2.74 & 9.95 & 5.44 & 6.27 & No \\
\hline SW-08 & $\begin{array}{l}\text { Yes, } 12 \text { active and } 2 \\
\text { inactive swine CAFOs }\end{array}$ & 0.02 & $<0.040$ & 16.70 & na & na & Unclear \\
\hline SW-13A & Yes, 1 swine CAFO & 5.9 & 35.4 & 65.70 & 18.92 & 9.95 & Yes \\
\hline SW-13B & Yes, 2 swine CAFOs & 7.0 & 27.5 & 51.80 & 19.98 & 10.42 & Yes \\
\hline SW-13 & Yes, 3 swine CAFOs & 3.0 & 0.390 & 33.10 & 22.04 & 9.16 & Yes \\
\hline SP-01A & $\begin{array}{l}\text { No, background } \\
\text { agricultural fields }\end{array}$ & 9.3 & $<0.040$ & 5.19 & na & na & No \\
\hline SP-01B & $\begin{array}{l}\text { Yes, } 1 \text { swine and } 1 \\
\text { poultry CAFOs }\end{array}$ & 10.6 & $<0.040$ & 5.93 & na & na & No \\
\hline SP-01C & Yes, 2 swine CAFOs & 11.8 & 0.592 & 31.10 & 27.99 & 9.74 & Yes \\
\hline SP-01 & $\begin{array}{l}\text { Yes, } 6 \text { swine and } 1 \\
\text { poultry CAFOs }\end{array}$ & 10.1 & 0.103 & 10.63 & 8.94 & 4.96 & No \\
\hline SP-04A & $\begin{array}{l}\text { No, background } \\
\text { agricultural fields }\end{array}$ & 2.3 & 0.877 & 9.25 & 12.52 & 10.79 & No \\
\hline SP-04B & $\begin{array}{l}\text { Yes, } 2 \text { swine and } 1 \\
\text { poultry CAFOs }\end{array}$ & 4.2 & 1.86 & 22.74 & 22.54 & 10.58 & Yes \\
\hline SP-04 & $\begin{array}{l}\text { Yes, } 4 \text { swine and } 1 \\
\text { poultry CAFOs }\end{array}$ & 2.1 & 0.110 & 21.24 & 17.01 & 9.58 & Yes \\
\hline SP-05A & Yes, 1 swine CAFO & 7.1 & 3.50 & 12.06 & 7.93 & 5.20 & No \\
\hline SP-05B & $\begin{array}{l}\text { Yes, } 1 \text { swine and } 1 \\
\text { poultry CAFOs }\end{array}$ & 9.2 & 2.62 & 12.16 & 8.75 & 6.91 & No \\
\hline SP-05 & $\begin{array}{l}\text { Yes, } 1 \text { swine and } 3 \\
\text { poultry CAFOs }\end{array}$ & 5.9 & 4.13 & 11.84 & 8.00 & 6.75 & No \\
\hline SP-09A & $\begin{array}{l}\text { Yes, } 3 \text { swine and } 1 \\
\text { poultry CAFOs }\end{array}$ & 5.9 & 3.20 & 43.60 & 23.02 & 14.21 & Yes \\
\hline SP-09 & $\begin{array}{l}\text { Yes, } 3 \text { swine and } 1 \\
\text { poultry CAFOs }\end{array}$ & 5.4 & 1.94 & 33.70 & 23.13 & 14.72 & Yes \\
\hline SP-11A & Yes, 2 swine CAFOs & 3.7 & 1.11 & 32.60 & 25.57 & 13.32 & Yes \\
\hline SP-11B & Yes, 4 swine CAFOs & 1.4 & 1.73 & 32.50 & 28.96 & 9.67 & Yes \\
\hline SP-11C & Yes, 1 swine CAFO & 9.5 & 2.98 & 12.66 & 11.91 & 8.63 & Yes \\
\hline SP-11D & Yes, 6 swine CAFOs & 4.8 & 1.01 & 31.10 & 24.21 & 6.69 & Yes \\
\hline SP-11 & $\begin{array}{l}\text { Yes, } 9 \text { swine and } 1 \\
\text { poultry CAFOs }\end{array}$ & 0.3 & $<0.040$ & 22.80 & na & na & Yes \\
\hline
\end{tabular}



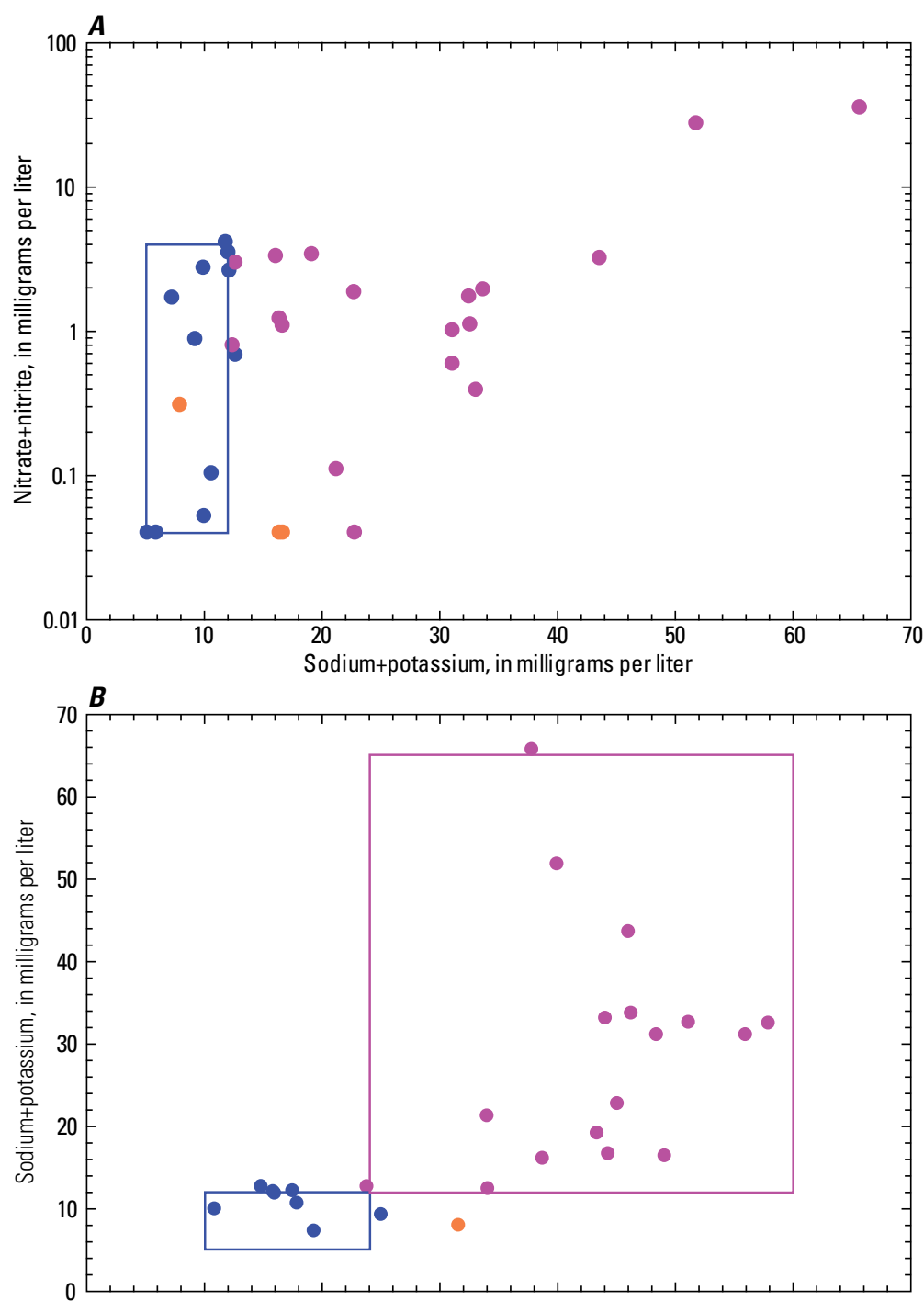

EXPLANATION

- Sites without manure influence Boundary delineating site results without manure influences

- Sites with manure influence Boundary delineating site results with manure influences

Sites with unclear results

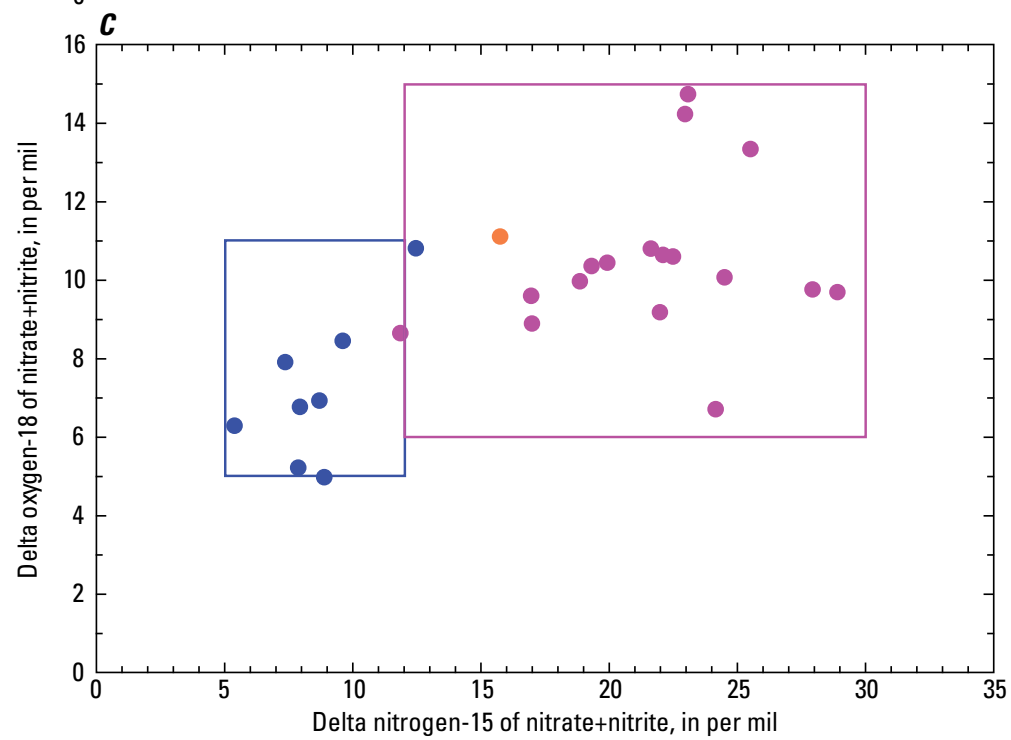

Figure 10. Graphs showing data comparisons of $(A)$ sodium plus potassium to nitrate plus nitrite, $(B)$ delta nitrogen-15 of nitrate plus nitrite to sodium plus potassium, and $(C)$ delta nitrogen-15 to delta oxygen-18 of nitrate plus nitrite for sites with and without CAFO manure influences and sites with unclear results based on the April 2013 dataset. 
sodium + potassium and nitrate+nitrite data for the sites without manure influences are shown in figure $10 \mathrm{~A}$. Boundaries delineating the general distributions in the nitrate + nitrite $\delta^{15} \mathrm{~N}$ and sodium+potassium data (fig. 10B) and the nitrate+nitrite $\delta^{15} \mathrm{~N}$ and $\delta^{18} \mathrm{O}$ data (fig. 10C) are shown for both the sites without and with manure influences. The nitrate + nitrite $\delta^{15} \mathrm{~N}$ and $\delta^{18} \mathrm{O}$ values for the sites without manure effects (fig. 10C) agree with the common $\delta^{15} \mathrm{~N}$ and $\delta^{18} \mathrm{O}$ values of nitrate derived from ammonium fertilizer or natural soil organic $\mathrm{N}$ displayed in figure 9. The nitrate+nitrite $\delta^{15} \mathrm{~N}$ and $\delta^{18} \mathrm{O}$ values for the sites with manure effects (fig. 10C) also agree with the $\delta^{15} \mathrm{~N}$ and $\delta^{18} \mathrm{O}$ values of nitrate commonly derived from animal manure sources (fig. 9).

The overall range of nitrate+ + nitrite concentrations was fairly similar for the sites with and without manure influences; however, sodium+potassium concentrations were higher for the sites with a manure influence than those without an influence (fig. 10A). Better separation among the sites is noted in the nitrate+nitrite $\delta^{15} \mathrm{~N}$ and sodium+potassium data (fig. 10B). The sites without manure influences had lower $\delta^{15} \mathrm{~N}$ values (about 5 to $12 \%$ ) and sodium+potassium concentrations (about 5 to $12 \mathrm{mg} / \mathrm{L}$ ) than the manure influenced sites, which are characterized by higher $\delta^{15} \mathrm{~N}$ values (about 12 to $30 \%$ ) and sodium+potassium concentrations (about 12 to $65 \mathrm{mg} / \mathrm{L}$ ). Comparison of the nitrate+nitrite $\delta^{15} \mathrm{~N}$ to $\delta^{18} \mathrm{O}$ data (fig. 10C) indicates that although the $\delta^{15} \mathrm{~N}$ values appear to segregate, the sites without and with manure influences tend to have overlapping $\delta^{18} \mathrm{O}$ values of about 5 to $11 \%$ and 6 to $15 \%$, respectively. For several sites, limited or inconsistent results made it difficult to determine whether water quality reflected background agricultural conditions or waste-manure effects. For example, the unclear results shown for some sites included a sodium+potassium concentration within the range of sites without manure influences (fig. 10A, $B$ ) but the elevated $\delta^{15} \mathrm{~N}$ value (fig. $10 B, C$ ) could be indicative of either a manure signature or denitrification effects on soil nitrate derived from inorganic fertilizer or natural organic $\mathrm{N}$.

\section{Identification of Study Watersheds Having Measurable CAFO Effects on Water Quality}

On the basis of the insights gained from the above evaluation of the April 2013 dataset, nitrate+nitrite and sodium+potassium concentrations and the nitrate+nitrite isotopic values $\left(\delta^{15} \mathrm{~N}\right.$ and $\left.\delta^{18} \mathrm{O}\right)$ for all 6 sampling periods at the 54 primary study sites (appendix A6) were evaluated to determine which of the $18 \mathrm{SW}$ and $18 \mathrm{SP}$ sites had apparent CAFO waste-manure effects on stream water quality. Results for the 18 BK study sites first were plotted to serve as a baseline, or background, dataset (fig. 11) against which the SW and SP site data could be compared. The reference boundaries determined for sites without and sites with measurable manure influences using the April 2013 dataset (fig. 10) also were included in figure 11 to aid examination of the results.
Overall, the baseline results for the BK sites fall within fairly well-defined clusters (fig. 11). Most of the nitrate+nitrite and sodium+potassium concentrations for the BK sites fall within the reference boundary for sites without waste-manure effects. Note that many of the BK sites had nitrate+nitrite concentrations less than the RL of $0.04 \mathrm{mg} / \mathrm{L}$. As previously discussed, denitrification is one of the important factors known to influence nitrate+nitrite concentrations at the study sites. The effects of denitrification are evident in the background nitrate+nitrite $\delta^{15} \mathrm{~N}$ results. The BK sites had nitrate+nitrite $\delta^{15} \mathrm{~N}$ values, up to about $17 \%$, that extended beyond the upper limit of about $12 \%$ for the reference boundary for sites without manure influences (fig. 11B). The nitrate+nitrite $\delta^{15} \mathrm{~N}$ and $\delta^{18} \mathrm{O}$ values for the BK sites plot along a best-fit regression line having a slope of 0.48 (fig. 11C), which is indicative of denitrification that causes coupled increases in the $\delta^{15} \mathrm{~N}$ to $\delta^{18} \mathrm{O}$ values by a $2: 1$ ratio. Increased isotopic values resulting from denitrification explains why some of the BK sites, with no waste-manure influences, had nitrate+nitrite $\delta^{15} \mathrm{~N}$ and $\delta^{18} \mathrm{O}$ values within the reference boundary reflecting manure influence.

Data for each of the SW and SP sites were plotted and compared against the figure 11 boundaries respresenting the BK site baseline data, as well as the sites without and with measurable manure influences, to categorize those SW and SP sites with results that (1) were similar to background conditions, or (2) had distinct differences indicating CAFO manure effects. It was impractical to include all of the comparison plots in the report. Therefore, for illustrative purposes, representative plots for selected sites with results similar to background conditions are shown in figure 12, and selected sites with results indicating manure influences are shown in figure 13.

Sites SW-14, SW-16, SP-05, and SP-15 had results similar to background conditions based on comparisons of their sodium+potassium to nitrate+nitrite concentrations (fig. 12A), nitrate+nitrite $\delta^{15} \mathrm{~N}$ values to sodium+potassium concentrations (fig. $12 B$ ), and nitrate + nitrite $\delta^{15} \mathrm{~N}$ to $\delta^{18} \mathrm{O}$ values (fig. $12 C$ ). The effects of denitrification can also be seen in the $\delta^{15} \mathrm{~N}$ results for site SP-15.

The effects of CAFO waste manures are indicated in some or all of the results for sites SW-04, SW-05, SP-12, and SP-16 as compared to the reference boundaries (fig. 13). Sites SW-05 and SP-16 had samples with results overlapping background conditions as well as manure influences. These site results likely reflect different instream mixtures of groundwater and overland runoff from areas with and without CAFOs where at times manure influences on water quality were not always evident. CAFO manure effects were evident in all of the sample results for sites SW-04 and SP-12 (fig. 13). Site SP-12, located immediately downstream from multiple swine CAFO waste-manure lagoons and application fields (appendix fig. A1-48), had high nitrate+nitrite $\delta^{15} \mathrm{~N}$ and $\delta^{18} \mathrm{O}$ values. The isotopic signatures of nitrate+nitrite derived from waste manures at this site possibly reflect the effects of different fractionation processes, such as ammonia volatilization and denitrification, that occurred before, during, and (or) after the applications of waste manures from the storage lagoons to the spray fields. 

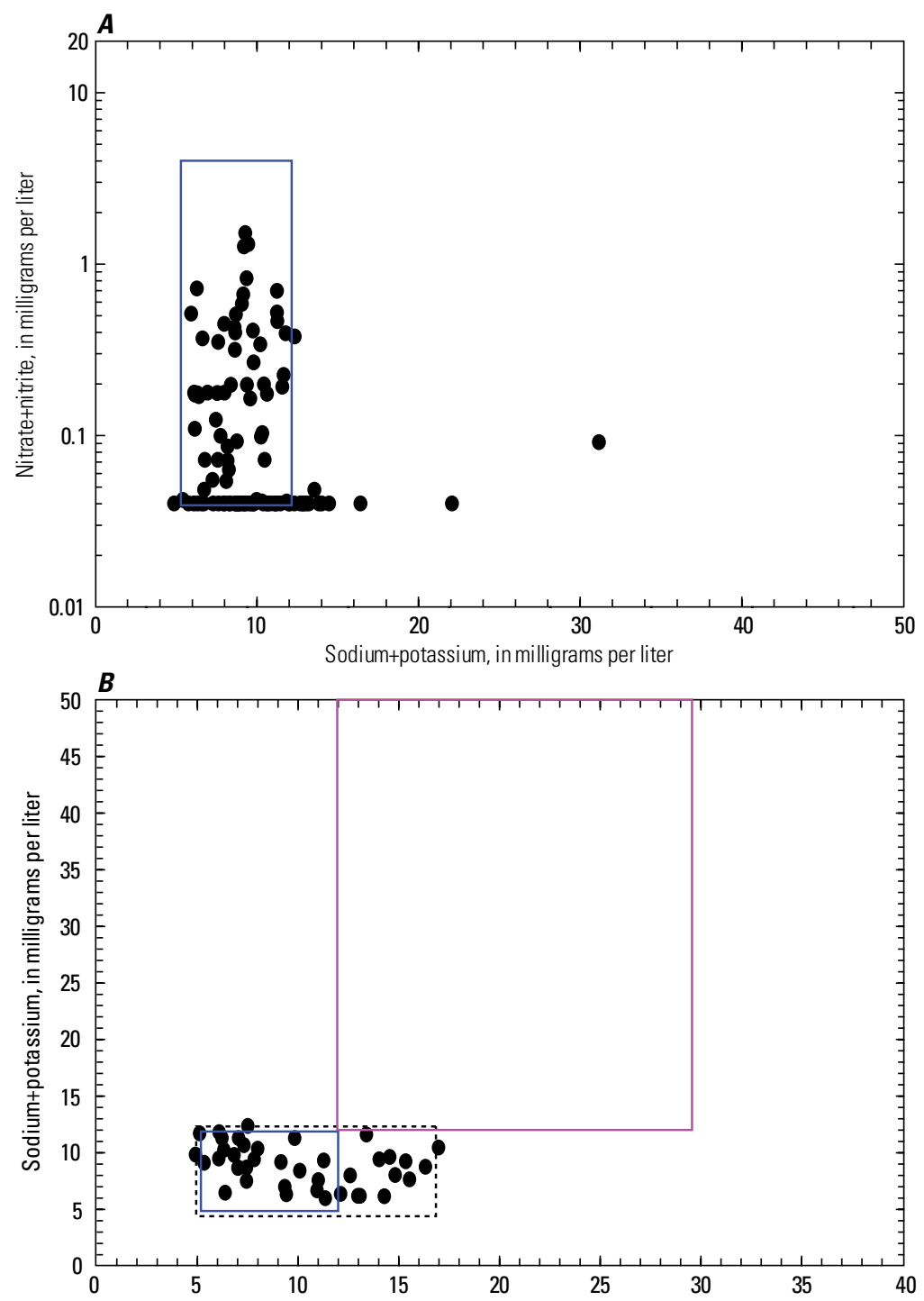

EXPLANATION

- Background site results

-.. Baseline boundary for background dataset

- Reference boundary (from fig. 10) for results without manure influences

Reference boundary (from fig. 10) for results

with manure influences

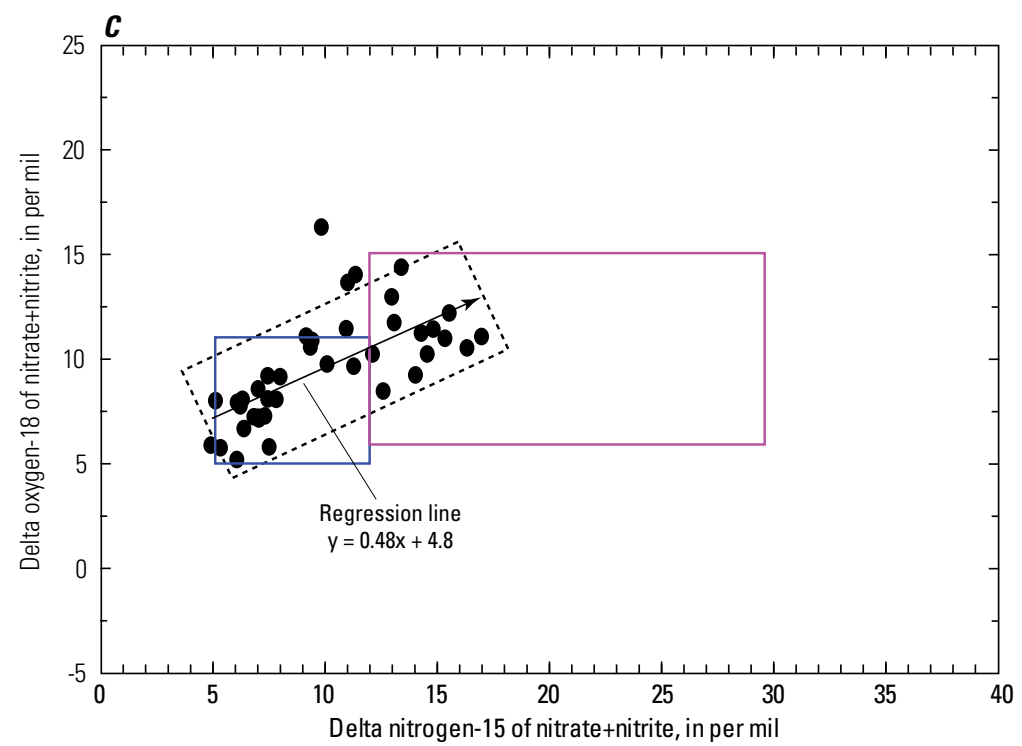

Figure 11. Graphs showing data comparisons of $(A)$ sodium plus potassium to nitrate plus nitrite, $(B)$ delta nitrogen-15 of nitrate plus nitrite to sodium plus potassium, and $(C)$ delta nitrogen-15 to delta oxygen-18 of nitrate plus nitrite for the background sites. 

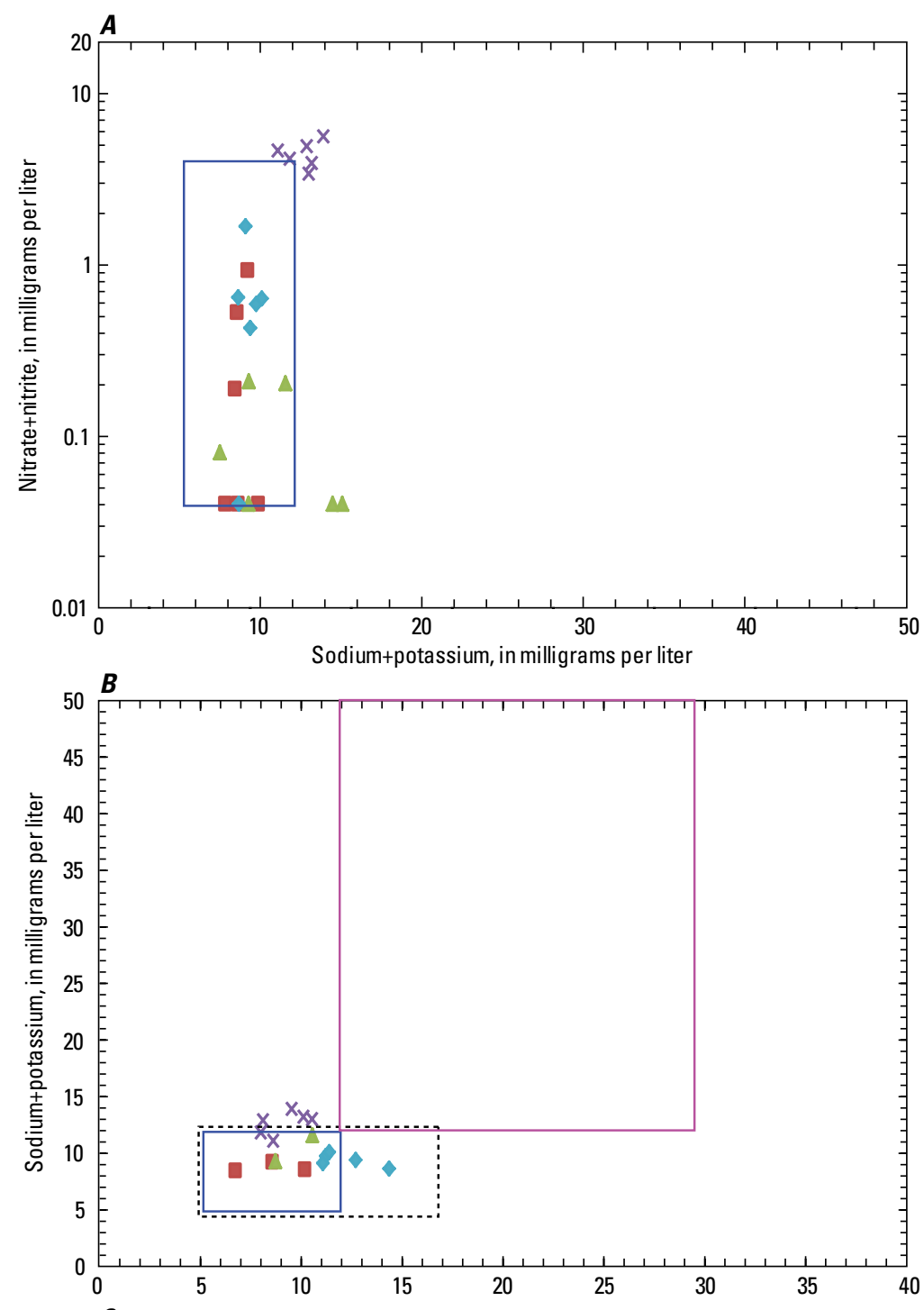

EXPLANATION

Sites with results similar to background conditions

SW-14

SW-16

$\times \quad$ SP-05

SP-15

-..- Baseline boundary for background dataset - Reference boundary (from fig. 10) for results without manure influences

- Reference boundary (from fig. 10) for results with manure influences

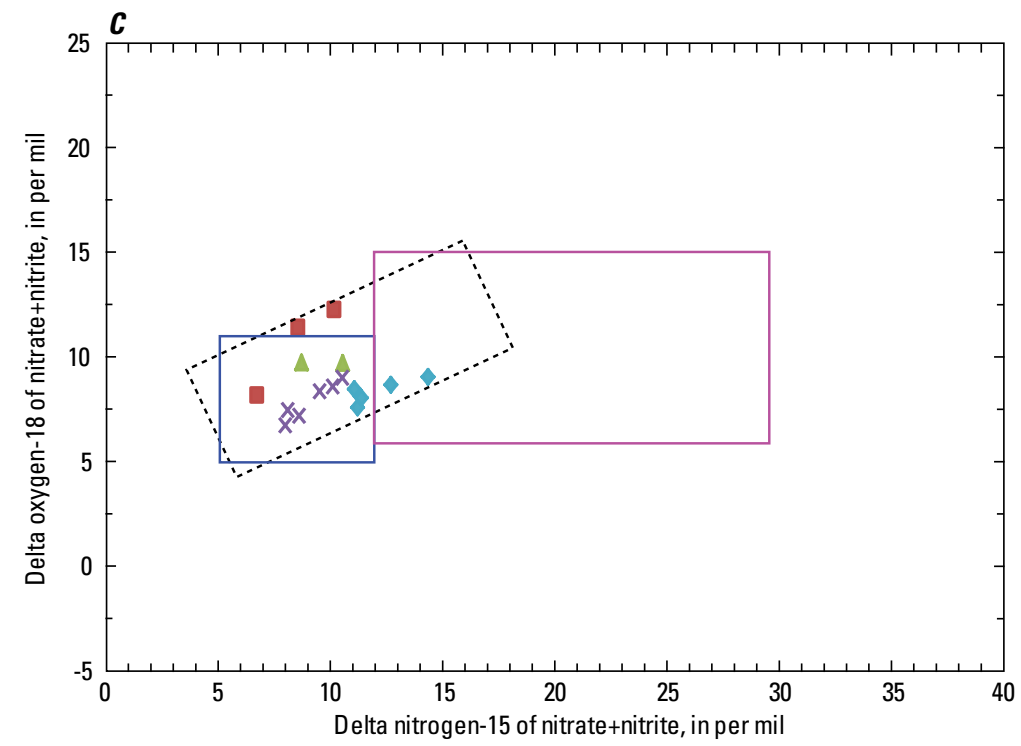

Figure 12. Graphs showing data comparisons of $(A)$ sodium plus potassium to nitrate plus nitrite, $(B)$ delta nitrogen-15 of nitrate plus nitrite to sodium plus potassium, and $(C)$ delta nitrogen-15 to delta oxygen-18 of nitrate plus nitrite at four representative sites (SW-14, SW-16, SP-05, and SP-15) with results similar to background conditions. 

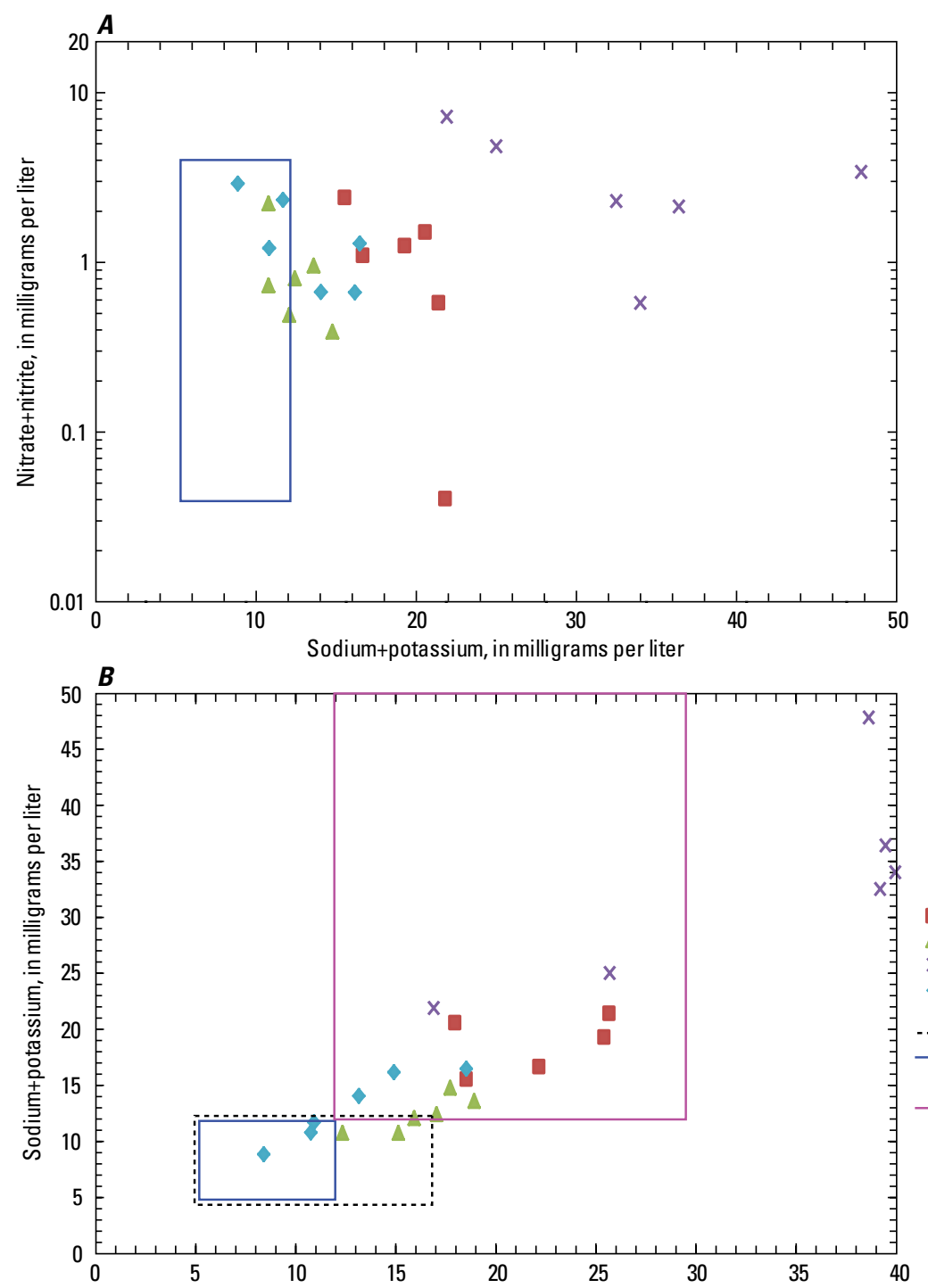

EXPLANATION

Sites with results indicating manure effects

- SW-04

SW-05

$\times \quad$ SP-12

SP-16

Baseline boundary for background dataset Reference boundary (from fig. 10) for results without manure influences

Reference boundary (from fig. 10) for results with manure influences

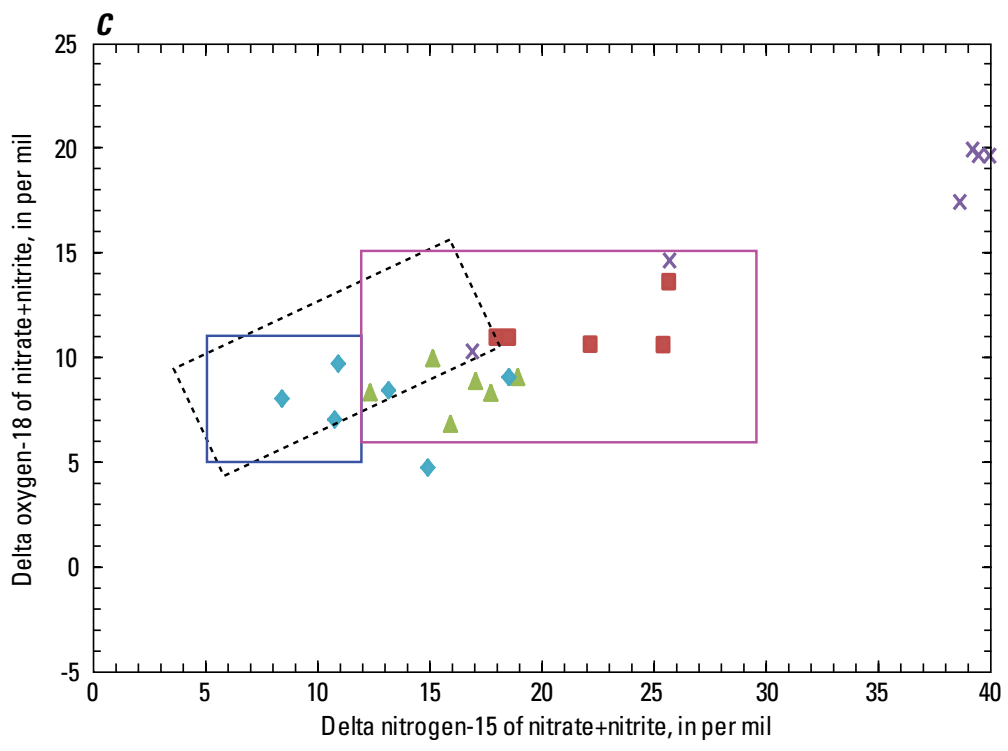

Figure 13. Graphs showing data comparisons of $(A)$ sodium plus potassium to nitrate plus nitrite, $(B)$ delta nitrogen-15 of nitrate plus nitrite to sodium plus potassium, and $(C)$ delta nitrogen-15 to delta oxygen-18 of nitrate plus nitrite at four representative sites (SW-04, SW-05, SP-12, and SP-16) with results indicating manure effects. 


\section{Surface-Water Quality in Agricultural Watersheds of the North Carolina Coastal Plain Associated with CAFOs}

On the basis of the comparisons of sodium+potassium concentrations, nitrate+nitrite concentrations, and the $\delta^{15} \mathrm{~N}$ and $\delta^{18} \mathrm{O}$ of nitrate+nitrite values, 10 of the $36 \mathrm{CAFO}$ sites (28 percent) had results similar to background conditions, and 21 of the sites (58 percent) had results with measurable CAFO manure effects (table 14). Note that the identification of those SW or SP watersheds as being similar to background conditions does not necessarily imply that CAFOs in those watersheds have no local influence on water quality, only that no distinction was noted at the watershed sampling location for the constituents that were examined. Three of the SW sites (SW-03, SW-08, and SW-15) and two of the SP sites (SP-03 and SP-08) had limited or indeterminate results for determining whether they were similar to background or manure influenced; these sites with unclear results were excluded from further evaluation.
The manure-influenced group of sites tended to have distinctly higher sodium + potassium concentrations (commonly between 11 and $33 \mathrm{mg} / \mathrm{L}$ ) and $\delta^{15} \mathrm{~N}$ values of nitrate+nitrite (commonly between 11 and $26 \%$ ) relative to both the background and similar to background groups of sites, which commonly had sodium + potassium concentrations between 6 and $14 \mathrm{mg} / \mathrm{L}$ and $\delta^{15} \mathrm{~N}$ values of nitrate+nitrite between 6 and $15 \%$ (table 14; appendix A6). Based on the six sampling periods from June 2012 to April 2013, sodium+potassium concentrations and $\delta^{15} \mathrm{~N}$ values of nitrate+nitrite appear to be useful water-quality indicators for differentiating streams with measurable CAFO manure effects. It would be beneficial to base future similar analyses on a larger number of samples that more fully reflect hydrologic and seasonal variability in water-quality conditions among sites of interest.

Table 14. Statistical summary of selected water-quality constituents for the background sites, CAFO sites with results similar to background conditions, and CAFO sites with results reflecting manure influences.

[diss., dissolved; mg/L, milligrams per liter; N, nitrogen; O, oxygen; +, plus; <, less than; $\delta$, delta; \%o, per mil]

\begin{tabular}{|c|c|c|c|c|c|c|c|c|c|c|c|c|}
\hline \multirow[b]{2}{*}{$\begin{array}{c}\text { Chemical } \\
\text { constituent } \\
\text { (unit) }\end{array}$} & \multicolumn{4}{|c|}{ Background sites ${ }^{1}$} & \multicolumn{4}{|c|}{ Similar to background sites ${ }^{2}$} & \multicolumn{4}{|c|}{ Manure-influenced sites ${ }^{3}$} \\
\hline & $\begin{array}{c}\text { Number } \\
\text { of } \\
\text { samples }\end{array}$ & $\begin{array}{c}\text { 10th } \\
\text { percentile }\end{array}$ & Median & $\begin{array}{c}\text { 90th } \\
\text { percentile }\end{array}$ & $\begin{array}{c}\text { Number } \\
\text { of } \\
\text { samples }\end{array}$ & $\begin{array}{c}\text { 10th } \\
\text { percentile }\end{array}$ & Median & $\begin{array}{c}\text { 90th } \\
\text { percentile }\end{array}$ & $\begin{array}{c}\text { Number } \\
\text { of } \\
\text { samples }\end{array}$ & $\begin{array}{c}\text { 10th } \\
\text { percentile }\end{array}$ & Median & $\begin{array}{c}\text { 90th } \\
\text { percentile }\end{array}$ \\
\hline $\begin{array}{l}\text { Sodium }+ \\
\text { potassium, } \\
\text { diss. }(\mathrm{mg} / \mathrm{L})\end{array}$ & 106 & 6.35 & 9.23 & 12.9 & 54 & 6.48 & 9.57 & 14.5 & 124 & 10.8 & 16.66 & 32.7 \\
\hline $\begin{array}{l}\text { Nitrate }+ \text { nitrite, } \\
\text { diss. }(\mathrm{mg} / \mathrm{L} \\
\text { as } \mathrm{N})\end{array}$ & 106 & $<0.040$ & 0.048 & 0.505 & 60 & $<0.040$ & 0.074 & 3.41 & 124 & $<0.040$ & 0.692 & 4.27 \\
\hline $\begin{array}{c}\delta^{15} \mathrm{~N} \text { of nitrate }+ \\
\text { nitrite }(\%)\end{array}$ & 40 & 6.08 & 9.39 & 15.10 & 27 & 7.33 & 6.74 & 12.42 & 95 & 10.80 & 16.28 & 25.70 \\
\hline $\begin{array}{c}\delta^{18} \mathrm{O} \text { of nitrate }+ \\
\text { nitrite }(\% 0)\end{array}$ & 40 & 6.26 & 9.43 & 13.29 & 27 & 4.96 & 2.54 & 11.42 & 95 & 6.50 & 9.16 & 14.62 \\
\hline
\end{tabular}

${ }^{1}$ The background, or baseline, dataset includes the results of all $18 \mathrm{BK}$ sites (BK-01 through BK-18).

${ }^{2}$ The sites with results deemed to be similar to background conditions include 6 SW sites (SW-02, 06, 07, 10, 14, and 16) and 4 SP sites (SP-01, 05, 15, and 17).

${ }^{3}$ The sites with results deemed to reflect manure influences include $9 \mathrm{SW}$ sites (SW-01, 04, 05, 09, 11, 12, 13, 17, and 18) and 12 SP sites (SP-02, 04, 06, $07,09,10,11,12,13,14,16$, and 18). 


\section{Watershed Attributes Associated With CAFO Water-Quality Effects}

Watershed environmental attributes were compared among the study sites with and without CAFO manure influences (see previous section). The five sites (SW-03, 08 and 15, and SP-03 and 08) with indeterminate results were not included in this analysis. The remaining 49 sites were grouped into three response categories: 18 background sites; 10 similar to background CAFO sites, and 21 manure-influenced CAFO sites. A classification tree model was developed to examine relations between selected watershed environmental variables and the three response categories (appendix A7).

The main intent in this analysis was to identify key differences in watershed characteristics associated with sites either having or not having measurable CAFO manure effects. Watershed characteristics analyzed as predictor (independent) variables in the model included drainage area size, land cover (percentages of forested land, cropland, grassland, and wetlands), soil drainage (percentages of HSGs total A, total $\mathrm{B}$, total C, and D), swine CAFO attributes, and poultry CAFO attributes (appendix A7). The swine CAFO attributes included the total number of permitted active swine CAFOs, total swine barns and barn density, total swine and swine density, total swine weight and weight density, total acres available for applying swine-waste manure and acre density, and total generated PAN for each watershed site. The poultry CAFO attributes available for examination with the classification tree analysis were limited to the total number of identified poultry CAFOs, total poultry barns, and poultry barn density for each site. Results of the classification tree analysis, including the splits in the tree model, the selected environmental variable and value defining each split, and the response category with the number of sites classified in each category, are illustrated in figure 14 and summarized in table 15.

Table 15. Classification tree model results for the 49 study sites.

[\#, number; $<$, less than; $\geq$, greater than or equal to; $>$, greater than; $\mathrm{mi}^{2}$, square mile; $\%$, percent; na; not applicable]

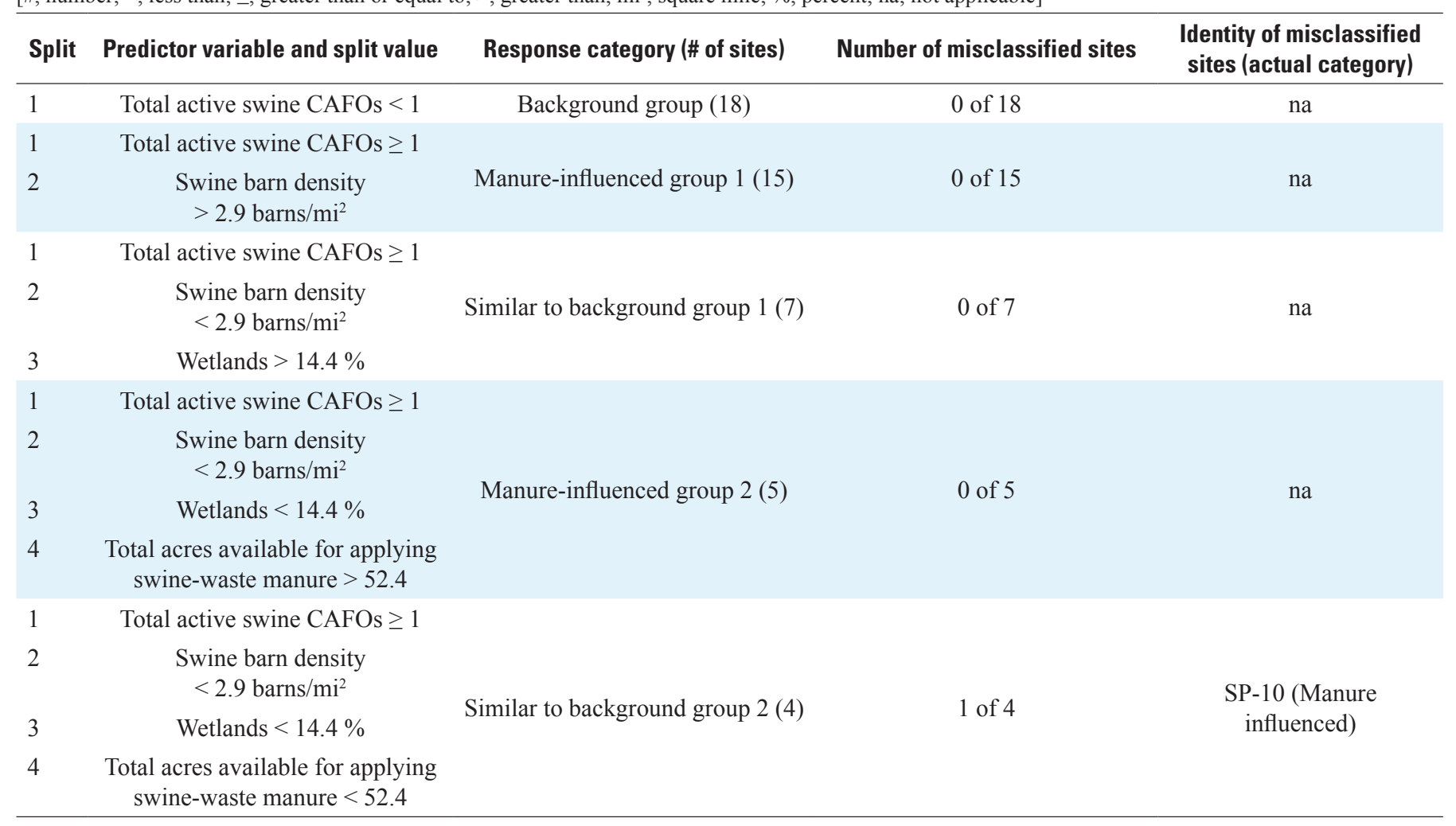




\section{Surface-Water Quality in Agricultural Watersheds of the North Carolina Coastal Plain Associated with CAFOs}

The tree model selected the presence/absence of active swine CAFOs, swine barn density, percentage of wetlands, and acres available for applying swine-waste manure as the best discriminators, or predictor variables, for classifying the study sites among the background, similar to background, and manure-influenced response categories or groups (fig. 14; table 15). The model was highly successful in accurately classifying the sites into the appropriate response categories. Only 1 of the 49 sites was misclassified (table 15). The first, or primary, split in the tree model was based on the presence/absence of active swine CAFOs in the watersheds (fig. 14). All 18 of the BK sites were placed in the background group because none of the BK sites contain any active swine CAFOs.

Interestingly, the $15 \mathrm{SW}$ sites and $16 \mathrm{SP}$ sites, which all had at least 1 active swine CAFO, were further differentiated into two groups for the manure-influenced category (referred to as manure-influenced groups 1 and 2) and two groups for the similar to background category (referred to as similar to background groups 1 and 2) on the basis of subsequent splits in swine barn density, percentage of wetlands, and total acres available for applying swine-waste manure (fig. 14; table 15). The splits among these four groups indicate how variations in these particular swine CAFO and land-cover variables may inhibit or promote the ability of the watersheds to mitigate manure effects on water quality in streams receiving inputs from swine CAFO application fields.

When swine barn density in the watersheds was greater than 2.9 barns $/ \mathrm{mi}^{2}, 15$ sites ( $7 \mathrm{SW}$ and $8 \mathrm{SP}$ sites) with measurable CAFO manure effects on water quality were correctly placed in manure-influenced group 1 (fig. 14). The SW and SP sites in manure-influenced group 2 and similar to background groups 1 and 2 all had swine barn densities that were less than 2.9 barns $/ \mathrm{mi}^{2}$ (fig. 14; table 15). Seven sites (4 SW and 3 SP sites) without measurable CAFO manure effects on water quality were correctly placed in similar to background group 1 when the amount of wetlands in the watershed was greater than 14.4 percent. In comparing manure-influenced group 1 to similar to background group 1 (fig. 14), the SW and SP sites with measurable CAFO manure effects had higher swine barn densities (median of 4.8 barns $/ \mathrm{mi}^{2}$ ), more acres available for applying swine manure (median of 243.7 acres), and less wetlands (median of 12.1 percent) relative to the SW and SP sites without measurable CAFO manure effects. Similar to background group 1 had lower swine barn densities (median of $\left.1.2 \mathrm{barns} / \mathrm{mi}^{2}\right)$, fewer acres available for applying swine manure (median of 66.9 acres), and more wetlands (median of 20.8 percent).

When both swine barn density was less than 2.9 barns/ $\mathrm{mi}^{2}$ and wetlands was less than 14.4 percent, the SW and SP sites with or without measurable CAFO manure effects were separated on the basis of the total acres available for applying swine-waste manure in the watersheds (fig. 14; table 15). Five sites (2 SW and 3 SP sites) were correctly placed in manure-influenced group 2 when total acres available were greater than 52.4; four sites (2 SW and $2 \mathrm{SP}$ sites) were placed in similar to background group 2 when total acres available were less than 52.4 (fig. 14). Similar to background group 2 contained misclassified site SP-10, which actually belongs to the manure-influenced category (table 15). Site SP-10 had a swine barn density of 2.7 barns $/ \mathrm{mi}^{2}$, just below the split value of $2.9 \mathrm{barns} / \mathrm{mi}^{2}$, wetlands of 8.7 percent, and total available acres of 39.2, which resulted in its placement in similar to background group 2 . The sites in manure-influenced group 2 and similar to background group 2 had comparable median values of swine barn density (2.2 and $2.5 \mathrm{barns} / \mathrm{mi}^{2}$, respectively) and wetlands (11.7 and 8.4 percent, respectively). The primary distinction between these groups is that the total available acres for applying swine manure for the sites in manure-influenced group 2 (median of 164.1 acres) were about 5 times higher than the total available acres for the sites in similar to background group 2 (median of 34.0 acres).

The classification tree analysis, as well as the other data evaluations in this report, indicate that land-applications of waste manure at swine CAFOs had an effect on water-quality conditions in streams at many, but not all, of the SW and SP study sites. Measurable effects of CAFO waste manures on stream water quality were most evident in those SW and SP watershed study sites having lower percentages of wetlands combined with higher swine barn densities and (or) higher total acres available for applying waste manure at the swine CAFOs. Conversely, the SW and SP watersheds with stream water quality similar to background agricultural conditions were associated with lower swine barn densities combined with higher percentages of wetlands or lower total acres available for applying waste manure at the swine CAFOs.

None of the poultry CAFO attributes examined with the tree model were selected as predictor variables for identifying differences between the sites with and without CAFO manure effects. This should not be misconstrued to indicate that poultry CAFO manures do not have an influence on stream water quality but rather may be a function of the limited poultry CAFO attribute data that were available for examination, as well as the nature of the watershed sites selected for this study, which had a primary emphasis on swine CAFOs. Thirteen of the 16 SP study sites included in the classification tree analysis (appendix A7) had substantially more swine barns (ranging from 4 to 59) than poultry barns (ranging from 1 to 8 ) in the watersheds. These watersheds likely received larger proportions of land-applied swine manure relative to poultry litter. Additional water-quality data, as well as more detailed information on poultry CAFO attributes (such as the types and numbers of poultry raised), from watersheds only containing poultry CAFOs would allow further comparisons to swine-only watersheds to better understand whether swine manure and poultry litter have similar or different effects on water quality.

The classification tree model provides a useful approach for exploring potential CAFO manure effects in similar, small (1 to $18 \mathrm{mi}^{2}$ ) Coastal Plain watersheds where water-quality data are lacking. Potential sites could be screened on the basis of the influential watershed attributes (swine barn density, 
acres available for applying swine manure, and percentage of wetlands) identified by the model. Results could help water-resource managers and researchers identify streams with high potential for manure influences on water quality in order to prioritize them for further investigation and (or) targeted best management practices. The classification tree model can be refined as additional CAFO attribute information and water-quality data become available, both for existing study sites as well as new locations. The inclusion of data on specific manure-disposal practices at both swine and poultry CAFOs (including specific application fields and the frequency, timing, and amounts of applied manures) would enhance understanding of the effects of swine and poultry waste manures on stream water quality in different agricultural settings of the North Carolina Coastal Plain.

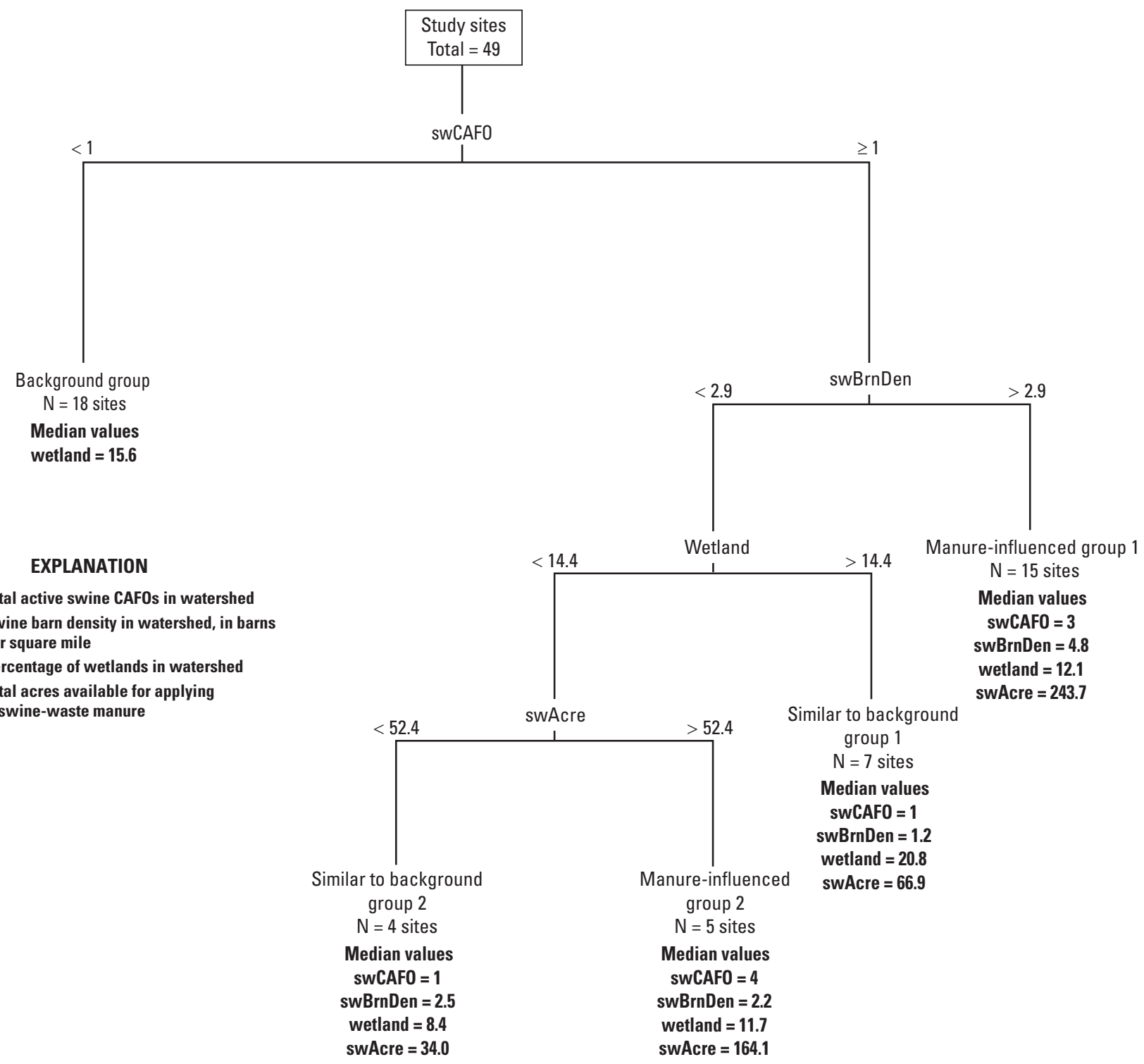

Figure 14. Classification tree model identifying the environmental predictor variables that best classified the 49 examined sites among the background, similar to background, and manure-influenced response categories. 


\section{Surface-Water Quality in Agricultural Watersheds of the North Carolina Coastal Plain Associated with CAFOs}

\section{Summary and Conclusions}

Water quality was evaluated at 54 agricultural stream sites in the North Carolina Coastal Plain for the period June 2012 through April 2013. Water-quality data and detailed watershed attributes were collected, compiled, and statistically analyzed to determine differences among streams draining watersheds with and without land-applied CAFO waste manures. Three general watershed land-use types, or groups, were examined during the study, including 18 background watersheds with no active CAFOs (BK sites), 18 watersheds with one or more active swine CAFOs but no poultry CAFOs (SW sites), and 18 watersheds with at least one active swine $\mathrm{CAFO}$ and one active dry-litter poultry CAFO (SP sites). The watersheds had drainage areas ranging from 1.2 to $17.5 \mathrm{mi}^{2}$ and land cover was composed predominantly of cropland, forests, and wetlands. Most watersheds had low gradient, swampy floodplain streams that were typically characterized by slow velocities, high organic matter, and relatively low dissolved oxygen. None of the watersheds contained permitted point-source discharge facilities, cattle CAFOs, or wet-poultry CAFOs. Conventional fertilizers used for crop production were the primary source of nutrients at the BK sites. Animalwaste manures applied to agricultural fields associated with the swine or poultry CAFOs represented additional sources of nutrients at the SW and SP study sites.

Water-quality data included field measurements of water temperature, specific conductance, $\mathrm{pH}$, and dissolved oxygen, and laboratory analyses of major ions, nutrients, and stable isotopes. Samples were collected at the 54 primary sites during 6 bimonthly sampling periods from June 2012 to April 2013. An additional 23 secondary sites within 9 of the primary watershed sites were sampled once during April 2013 to provide additional data at stream sites directly adjacent or in close proximity to swine CAFOs and (or) background agricultural areas. Regional precipitation and streamflow data, along with $\delta^{2} \mathrm{H}$ and $\delta^{18} \mathrm{O}$ isotopic results for precipitation and stream samples, were used to assess general hydrologic conditions during the sampling periods.

ANOVA and multiple-comparison statistical tests were performed to characterize differences in stream water quality among the six sampling periods and the three (BK, SW, and SP) watershed land-use types. Most of the water-quality properties and constituents varied significantly among sampling periods, changing both seasonally and in response to hydrologic conditions. Nutrient differences among the sampling periods indicate that the relations between seasonal climatic differences, streamflow conditions, and instream biotic and abiotic processes are complex, and their integrated effects can have varying degrees of influence on individual nutrients in different watersheds. These findings are important to consider when developing approaches to assess stream nutrient conditions in similar Coastal Plain settings and can inform the development of sampling strategies that capture seasonal and (or) hydrologic variability. For example, the highest median concentrations of dissolved oxygen and nitrate+nitrite were observed during February 2013, when higher streamflows appeared to reflect more overland contributions of nitrate from upstream field-drainage ditches. Nitrate in the field ditches is carried to the main stem of the streams during higher flows and is subject to less instream processing, including denitrification and assimilation, when stream water temperatures are colder and dissolved oxygen concentrations are elevated. Nitrate+nitrite tended to be lowest during warm and dry sampling periods, when conditions were favorable for denitrification. In contrast, median concentrations of ammonia, total organic N, ortho-P, and total P were lowest during February. Environmental factors that likely influenced the various forms and instream concentrations of the $\mathrm{N}$ and $\mathrm{P}$ constituents include assimilation and release by algae and aquatic plants, redox conditions, microbially mediated reactions, adsorption and desorption processes, and biogeochemical exchange between streambed sediment and the overlying water column.

Water quality also varied significantly among the three watershed land-use types. Median values of specific conductance, several major ions (magnesium, sodium, potassium, and chloride), and nitrogen fractions (ammonia+organic $\mathrm{N}$, ammonia, nitrate + nitrite, total $\mathrm{N}$, and $\delta^{15} \mathrm{~N}$ of nitrate+nitrite) were higher for the SW and SP land-use groups as compared to the BK group, which have no active CAFOs. The higher concentrations of these constituents reflect the influence of swine-waste manure storage or applications at the SW sites and swine- and (or) poultry-waste manure storage or applications at the SP sites. No significant differences in water temperature, dissolved oxygen, calcium, total organic N, ortho-P, total P, or $\delta^{18} \mathrm{O}$ of nitrate + nitrite were noted among the land-use groups. The disparity observed between $\mathrm{N}$ and $\mathrm{P}$ response among the site groups may reflect differences in transport pathways or instream processing that influenced instream concentrations of these two classes of nutrients. When comparing the land-use groups, there was an overall measurable effect of animal-waste manures on stream water quality for the $\mathrm{SW}$ and $\mathrm{SP}$ watersheds relative to the $\mathrm{BK}$ watersheds; however, this does not mean that $\mathrm{CAFO}$ waste manures had an observable effect on water-quality conditions at every SW and SP site. Additional evaluations were performed on the water-quality data to distinguish those SW and SP sites where effects of CAFO waste manures were evident.

At the majority of individual SW and SP watersheds, measurable CAFO effects on water quality were clearly distinguished. At other sites, effects were less evident. Elevated concentrations of nitrate+nitrite did not necessarily indicate a CAFO effect; conversely, low nitrate+nitrite concentrations did not necessarily indicate the absence of a CAFO effect. An integrated evaluation of nitrate+nitrite concentrations, sodium+potassium concentrations, and stable isotopes $\left(\delta^{15} \mathrm{~N}\right.$ and $\delta^{18} \mathrm{O}$ ) of nitrate+nitrite was used to differentiate which SW and SP sites did or did not have a CAFO waste-manure signature.

Streams with CAFO manure effects typically had higher sodium+potassium concentrations (commonly between 11 and $33 \mathrm{mg} / \mathrm{L}$ ) and $\delta^{15} \mathrm{~N}$ values of nitrate+nitrite (commonly between 11 and $26 \%$ ) relative to streams reflecting background agricultural conditions, which commonly had sodium+potassium 
concentrations between 6 and $14 \mathrm{mg} / \mathrm{L}$ and $\delta^{15} \mathrm{~N}$ values of nitrate+nitrite between 6 and $15 \%$. Denitrification affected the $\delta^{15} \mathrm{~N}$ and $\delta^{18} \mathrm{O}$ signatures of nitrate+nitrite at some sites and must be accounted for during interpretations of nutrient sources.

As part of the evaluation, individual SW and SP sites were differentiated into two groups, including (1) those with results that were similar to background conditions, and (2) those with results reflecting CAFO waste-manure effects. Ten of the $36 \mathrm{SW}$ and SP sites (28 percent) had water quality similar to background conditions. Twenty-one of the SW and SP sites (58 percent) had distinct water-quality differences, reflecting swine- and (or) poultry CAFO manure effects. Five of the SW and SP sites (14 percent) had limited or indeterminate results for determining whether they were similar to background or manure influenced; these sites were omitted from further evaluation. On the basis of the results of this study, it is apparent that land-applications of waste manure at swine CAFOs influenced ion and nutrient chemistry in many of the North Carolina Coastal Plain streams that were studied. In particular, sodium+potassium concentrations coupled with $\delta^{15} \mathrm{~N}$ values of nitrate+nitrite were useful water-quality indicators for distinguishing sites with measurable CAFO manure effects.

Relations in watershed environmental attributes among the similar to background and manure-influenced site groups were examined through classification tree analysis. The classification tree model identified swine barn density, percentage of wetlands, and total acres available for applying swine-waste manures as the best discriminators, or predictor variables, for classifying sites among the similar to background and manureinfluenced groups. Variations in these particular attributes appeared to influence those watersheds where CAFO effects on water quality were either evident or mitigated. Measurable effects of CAFO waste manures on stream water quality were most evident in those SW and SP watersheds having lower percentages of wetlands combined with higher swine barn densities and (or) higher total acres available for applying waste manure at the swine CAFOs. Stream water quality was similar to background agricultural conditions in SW and SP watersheds with lower swine barn densities coupled with higher percentages of wetlands or lower acres available for swine manure applications.

The classification tree model provides a useful approach for examining potential CAFO manure effects on stream water quality among similar Coastal Plain watersheds, including those where water-quality data are lacking. The model can serve as an exploratory tool to identify watersheds that might warrant further examination and (or) targeted best management practices. The study model can be refined as additional watershed attribute information and water-quality data become available. Additional water-quality data, poultry CAFO attribute data, and information on manure disposal practices at both swine and poultry CAFOs would enhance scientific understanding of the effects of swine and poultry waste manures on stream water quality under different agricultural settings.

\section{References Cited}

American Public Health Association, 1998, Standard methods for the examination of water and wastewater (20th ed.): Washington, D.C., American Public Health Association, American Water Works Association, and Water Environment Federation, Method 3120, p. 3-37 to 3-43.

Barker, J.C., Zublena, J.P., and Walls, F.R., 1994, Animal and poultry manure production and characterization: North Carolina State University, Department of Biological and Agricultural Engineering, accessed May 5, 2014, at http://www.bae.ncsu.edu/topic/animal-waste-mgmt/ program/land-ap/barker/a\&pmp\&c/content.htm.

Bonn, B.A., 2008, Using the U.S. Geological Survey National Water Quality Laboratory LT-MDL to evaluate and analyze data: U.S. Geological Survey Open-File Report 2008-1227, $73 \mathrm{p}$.

Böttcher, J., Strebel, O., Voerkelius, S., and Schmidt, H.L., 1990, Using isotope fractionation of nitrate-nitrogen and nitrate-oxygen for evaluation of microbial denitrification in a sandy aquifer: Journal of Hydrology, v. 114, p. 413-424.

Breiman, L., Friedman, J.H., Olshen, R.A., and Stone, C.J., 1984, Classification and regression trees: Boca Raton, Fla., Chapman \& Hall/CRC, 368 p.

Burkholder, J.M., Dickey, D.A., Kinder, C.A., Reed, R.A., Mallin, M.A., McIver, M.R., Cahoon, L.B., Melia, G., Brownie, C., Smith, J., Deamer, N., Springer, J., Glasgow, H.B., and Toms, D., 2006, Comprehensive trend analysis of nutrients and related variables in a large eutrophic estuaryA decadal study of anthropogenic and climatic influences: Limnology and Oceanography, v. 51, p. 463-487.

Burkholder, J.M., and Glasgow, H.B., Jr., 1997, Pfiesteria piscicida and other Pfiesteria-like dinoflagellatesBehavior, impacts and environmental controls: Limnology and Oceanography, v. 42, p. 1052-1075.

Burkholder, J.M., Glasgow, H.B., Jr., and Hobbs, C.W., 1995, Distribution and environmental conditions for fish kills linked to a toxic ambush predator dinoflagellates: Marine Ecology Progress Series, v. 124, p. 43-61.

Casciotti, K.L., Böhlke, J.K., McIlvin, M.R., Mroczkowski, S.J., and Hannon, J.E., 2007, Oxygen isotopes in nitrite: analysis, calibration, and equilibration: Analytical Chemistry, v. 79, p. 2427-2436.

Casciotti, K.L., and McIlvin, M.R., 2007, Isotopic analyses of nitrate and nitrite from reference mixtures and application to Eastern Tropical North Pacific waters: Marine Chemistry, v. 107, p. 184-201. 
Casciotti, K.L., Sigman, D.M., Galanter Hastings, M., Böhlke, J.K., and Hilkert, A., 2002, Measurement of the oxygen isotopic composition of nitrate in seawater and freshwater using the denitrifier method: Analytical Chemistry, v. 74, p. 4905-4912.

Copeland, Claudia, 2010, Animal waste and water qualityEPA regulation of concentrated animal feeding operations (CAFOs): Washington, D.C., Congressional Research Service Report RL31851, 21 p.

Coplen, T.B., Qi, Haiping, Révész, Kinga, Casciotti, Karen, and Hannon, J.E., 2012, Determination of the $\delta^{15} \mathrm{~N}$ and $\delta^{18} \mathrm{O}$ of nitrate in water; RSIL lab code 2900, chap. 17 of Stable isotope-ratio methods, sec. C of Révész, Kinga, and Coplen, T.B., eds., Methods of the Reston Stable Isotope Laboratory (slightly revised from version 1.0 released in 2007): U.S. Geological Survey Techniques and Methods, book 10, 35 p., accessed May 11, 2015, at http://pubs.usgs.gov/tm/2006/tm10c17/.

Crouse, D.A., and Shaffer, K., 2011, SoilFactsGuidelines for the commercial application of poultry litter: North Carolina Cooperative Extension Service Publication AG-439-76W, accessed June 19, 2013, at http:/www.soil.ncsu.edu/publications/extension.htm.

David, M.B., Gentry, L.E., Kovacic, D.A., and Smith, K.M., 1997, Nitrogen balance in and export from an agricultural watershed: Journal of Environmental Quality, v. 26, p. 1038-1048.

Dukes, M.D., and Evans, R.O., 2006, Impact of agriculture on water quality in the North Carolina Middle Coastal Plain: Journal of Irrigation and Drainage Engineering, v. 132, p. 250-262.

Dunne, E.J., and Reddy, R.K., 2005, Phosphorus biogeochemistry of wetlands in agricultural watersheds, in Dunne, E.J., Reddy, K.R., and Carton, O.T., eds., Nutrient management in agricultural watersheds - A wetlands solution: The Netherlands, Wageningen Academic Publishers, p. 105-119.

Evans, R.O., Gilliam, J.W., and Skaggs, R.W., 1991, Controlled drainage management guidelines for improving drainage water quality: Raleigh, North Carolina Cooperative Extension Service, Bulletin AG-443.

Evans, R.O., Westerman, P.W., and Overcash, M.R., 1984, Subsurface drainage water quality from land application of swine lagoon effluent: Transactions of the American Society of Agricultural Engineers, v. 27, no. 2, p. 473-478.

Fishman, M.J., ed., 1993, Methods of analysis by the U.S. Geological Survey National Water Quality LaboratoryDetermination of inorganic and organic constituents in water and fluvial sediments: U.S. Geological Survey Open-File Report 93-125, 217 p.
Fishman, M.J., and Friedman, L.C., 1989, Methods for determination of inorganic substances in water and fluvial sediments: U.S. Geological Survey Techniques of WaterResources Investigations, book 5, chap. A1, 545 p.

Fogg, G.E., Rolston, D.E., Decker, D.L., Louie, D.T., and Grismer, M.E., 1998, Spatial variation in nitrogen isotope values beneath nitrate contamination sources: Ground Water, v. 36, no. 3, p. 418-426.

Fry, J., Xian, G., Jin, S., Dewitz, J., Homer, C., Yang, L., Barnes, C., Herold, N., and Wickman, J., 2011: Completion of the 2006 national land cover database for the conterminous United States, Photogrammetric Engineering \& Remote Sensing, v. 77, no. 9, p. 858-864.

Gilliam, J.W., Osmond, D.L., and Evans, R.O., 1997, Selected agricultural best management practices to control nitrogen in the Neuse River basin: Raleigh, North Carolina State University, North Carolina Agricultural Research Service Technical Bulletin 311.

Glasgow, H.B., and Burkholder, J.M., 2000, Water quality trends and management implications from a five-year study of a eutrophic estuary: Ecological Applications, v. 10, no. 4, p. 1024-1046.

Harden, S.L., 2008, Microbial and nutrient concentration and load data during stormwater runoff at a swine concentrated animal feeding operation in the North Carolina Coastal Plain, 2006-2007: U.S. Geological Survey Open-File Report 2008-1156, 22 p.

Harden, S.L., Cuffney, T.F., Terziotti, Silvia, and Kolb, K.R., 2013, Relation of watershed setting and stream nutrient yields at selected sites in central and eastern North Carolina, 1997-2008: U.S. Geological Survey Scientific Investigations Report 2013-5007, 47 p.

Harden, S.L., and Spruill, T.B., 2004, Ionic composition and nitrate in drainage water from fields fertilized with different nitrogen sources, Middle Swamp Watershed,

North Carolina, August 2000-August 2001: U.S. Geological Survey Scientific Investigations Report 2004-5123, 14 p.

Harden, S.L., and Spruill, T.B., 2008, Factors affecting nitrate delivery to streams from shallow ground water in the North Carolina Coastal Plain: U.S. Geological Survey Scientific Investigations Report 2008-5021, 39 p.

Helsel, D.R., and Hirsch, R.M., 1992, Statistical methods in water resources: Elsevier, 522 p. (Also available online as U.S. Geological Survey Techniques of Water-Resources Investigations, book 4, chap. A3 (2002), accessed February 2014 at http://pubs.usgs.gov/twri/twri4a3/html/ pdf.html.) 
Hubbard, R.K., Newton, G.L., and Hill, G.M., 2004, Water quality and the grazing animal: Journal of Animal Science, v. 82, p. E255-E263.

Huffman, R.L., 2004, Seepage evaluation of older swine lagoons in North Carolina: Transactions of the American Society of Agricultural Engineers, v. 47, no. 5, p. 1507-1512.

Hunt, P.G., Stone, K.C., Humenik, F.J., and Rice, J.M., 1995, Impact of animal waste on water quality in an eastern Coastal Plain watershed, in Steele, K., ed., Animal waste and the land-water interface: Chelsea, Mich., Lewis Publishers, p. 257-264.

Israel, D.W., Showers, W.J., Fountain, M., and Fountain, J., 2005, Nitrate movement in shallow ground water from swine-lagoon-effluent spray fields managed under current application regulations: Journal of Environmental Quality, v. 34 , p. $1828-1842$.

Jaynes, D.B., Colvin, T.S., Karlen, D.L., Cambardella, C.A., and Meek, D.W., 2001, Nitrate loss in subsurface drainage as affected by nitrogen fertilizer rate: Journal of Environmental Quality, v. 30, p. 1305-1314.

Karr, J.D., Showers, W.J., Gilliam, W., and Andres, A.S., 2001, Tracing nitrate transport and environmental impact from intensive swine farming using delta nitrogen-15: Journal of Environmental Quality, v. 30, p. 1163-1175.

Kendall, C., 1998, Tracing nitrogen sources and cycling in catchments, in Kendall, C., and McDonnell, J.J., eds., Isotope tracers in catchment hydrology: Amsterdam, Elsevier, p. 519-576.

Kendall, C., and Coplen, T.B., 2001, Distribution of oxygen-18 and deuterium in river waters across the United States: Hydrological Processes, v. 15, p. 1363-1393.

Kendall, C., Elliott, E.M., and Wankel, S.D., 2007, Tracing anthropogenic inputs of nitrogen to ecosystems, in Michener, R.H., and Lajtha, K., eds., Stable isotopes in ecology and environmental science, : Malden, Mass., Blackwell Publishing, p. 375-449.

Korom, S.F., 1992, Natural denitrification in the saturated zone-A review: Water Resources Research, v. 41, p. 1657-1668.

Luettich, R.A., McNinch, J.E., Paerl, H., Peterson, C.H., Wells, J.T., Alperin, M., Martens, C.S., and Pinckney, J.L., 2000, Neuse River estuary modeling and monitoring project stage 1-Hydrography and circulation, water column nutrients and productivity, sedimentary processes and benthicpelagic coupling, and benthic ecology: The University of North Carolina Water Resources Research Institute, Report 325-B.
Mainstone, C.P., and Parr, W., 2002, Phosphorus in rivers-Ecology and management: The Science of the Total Environment, v. 282-283, p. 25-47.

Mallin, M.A., and Cahoon, L.B., 2003, Industrialized animal production-A major source of nutrient and microbial pollution to aquatic ecosystems: Population and Environment, v. 24 , no. 5 , p. 369-385.

McMahon, G., and Lloyd, O.B., Jr., 1995, Water-quality assessment of the Albemarle-Pamlico drainage basin, North Carolina and Virginia_-Environmental setting and waterquality issues: U.S. Geological Survey Open-File Report 95-136, 72 p.

McMahon, P.B., and Böhlke, J.K., 1996, Denitrification and mixing in a stream-aquifer system-Effects on nitrate loading to surface water: Journal of Hydrology, v. 186, p. $105-128$.

Mulholland, P.J., 1992, Regulation of nutrient concentrations in a temperate forest stream-Roles of upland, riparian, and instream processes: Limnology and Oceanography, v. 37, p. $1512-1526$.

Mulholland, P.J., and Hill, W.R., 1997, Seasonal patterns in streamwater nutrient and dissolved organic carbon concentrations - Separating catchment flow path and in-stream effects: Water Resources Research, v. 33, p. 1297-1306.

Nelson, N.O., Parsons, J.E., and Mikkelsen, R.L., 2005, Fieldscale evaluation of phosphorus leaching in acid sandy soils receiving swine waste: Journal of Environmental Quality, v. 34, p. 2024-2035.

North Carolina Department of Agriculture and Consumer Services, 2012, 2012 Agricultural statistics: North Carolina Department of Agriculture and Consumer Services, Agricultural Statistics Division, accessed June 18, 2013, at http://www.ncagr.gov/stats/index.htm.

North Carolina Division of Water Resources, 2013, Animal Feeding Operations, Facility Map, List of Permitted Animal Facilities: North Carolina Department of Environment and Natural Resources Division of Water Resources, accessed January 2013, at http://portal.ncdenr.org/web/wq/animal-facility-map.

North Carolina Floodplain Mapping Program, 2012, Floodplain Mapping Information System, accessed January 2012, at http://www.ncfloodmaps.com/.

Novak, J.M., Watts, D.W., Hunt, P.G., and Stone, K.C., 2000, Phosphorus movement through a Coastal Plain soil after a decade of intensive swine manure application: Journal of Environmental Quality, v. 29, no. 4, p. 1310-1315. 
Osmond, D.L., and Kang, J., 2008, SoilFacts, Nutrient removal by crops in North Carolina: North Carolina Cooperative Extension Service Publication AG-439-16W, accessed June 19, 2013, at http://www.soil.ncsu.edu/ publications/extension.htm.

Paerl, H.W., Valdes, L.M., Joyner, A.R., and Piehler, M.F., 2004, Solving problems resulting from solutions - Evolution of a dual management strategy for the eutrophying Neuse River estuary, North Carolina: Environmental Science and Technology, v. 38, p. 3068-3073.

Patton, C.J., and Kryskalla, J.R., 2011, Colorimetric determination of nitrate plus nitrite in water by enzymatic reduction, automated discrete analyzer methods: U.S. Geological Survey Techniques and Methods, book 5, chap. B8, 34 p.

Patton, C.J., and Truitt, E.P., 2000, Methods of analysis by the U.S. Geological Survey National Water Quality Laboratory-Determination of ammonium plus organic nitrogen by a Kjeldahl digestion method and an automated photometric finish that includes digest cleanup by gas diffusion: U.S. Geological Survey Open-File Report 00-170, 31 p.

Puckett, L.J., 2004, Hydrogeologic controls on the transport and fate of nitrate in ground water beneath riparian buffer zones-Results from thirteen studies across the United States: Water Science and Technology, v. 49, no. 3, p. 47-53.

Randall, G.W., and Mulla, D.J., 2001, Nitrate nitrogen in surface waters as influenced by climatic conditions and agricultural practices: Journal of Environmental Quality, v. 30, p. $337-344$.

Révész, Kinga, and Coplen, T.B., 2008a, Determination of the $\delta\left({ }^{2} \mathrm{H} /{ }^{1} \mathrm{H}\right)$ of water-RSIL lab code 1574 , chap. $\mathrm{C} 1$ of Révész, Kinga, and Coplen, T.B, eds., Methods of the Reston Stable Isotope Laboratory: U.S. Geological Survey Techniques and Methods 10-C1, 27 p.

Révész, Kinga, and Coplen, T.B., 2008b, Determination of the $\delta\left({ }^{18} \mathrm{O} /{ }^{16} \mathrm{O}\right)$ of water-RSIL lab code 489 , chap. C2 of Révész, Kinga, and Coplen, T.B, eds., Methods of the Reston Stable Isotope Laboratory: U.S. Geological Survey Techniques and Methods 10-C2, 28 p.

Rothenberger, M.B., Burkholder, J.M., and Brownie, C., 2009, Long-term effects of changing land use practices on surface water quality in a coastal river and lagoonal estuary: Environmental Management, v. 44, p. 505-523.

Seitzinger, S., Harrison, J.A., Böhlke, J.K., Bouwman, A.F., Lowrance, R., Peterson, B., Tobias, C., and Van Drecht, G., 2006, Denitrification across landscapes and waterscapes-A synthesis: Ecological Applications, v. 16, no. 6, p. 2064-2090.
Sigman, D.M., Casciotti, K.L., Andreani, M., Barford, C., Galanter, M., and Böhlke, J.K., 2001, A bacterial method for the nitrogen isotopic analysis of seawater and freshwater: Analytical Chemistry, v. 73, p. 4145-4153.

Sims, J.T., Bergstörm, L., Bowman, B.T., and Oenema, O., 2005, Nutrient management for intensive animal agriculture-Policies and practices for sustainability: Soil Use and Management, v. 21, p. 141-151.

Smith, J.T., and Evan, R.O., 1998, Evaluation of BMPs to improve drainage water quality from agricultural land irrigated with swine lagoon effluent, in Brown, L.C., ed., Drainage in the 21 st century-Food production and the environment: Proceedings of the 7th International Drainage Symposium, American Society of Agricultural Engineers, Orlando Fla., March 8-11, 1998, p. 9-16.

Soil Survey Staff, Natural Resources Conservation Service, United States Department of Agriculture [n.d.]: Web Soil Survey, accessed March 4, 2013, at http://websoilsurvey.nrcs.usda.gov/.

Speiran, G.K., Hamilton, P.A., and Woodside, M.D., 1998, Natural processes for managing nitrate in ground water discharged to Chesapeake Bay and other surface waters - More than forest buffers: U.S. Geological Survey Fact Sheet 178-97, 4 p.

Spruill, T.B., 2000, Statistical evaluation of effects of riparian buffers on nitrate and ground-water quality: Journal of Environmental Quality, v. 29, no. 5, p. 1523-1538.

Spruill, T.B., Harned, D.A., Ruhl, P.M., Eimers, J.L., McMahon, G., Smith, K.E., Galeone, D.R., and Woodside, M.D., 1998, Water quality in the Albemarle-Pamlico drainage basin, North Carolina and Virginia, 1992-95: U.S. Geological Survey Circular 1157, 36 p.

Spruill, T.B., Showers, W.J., and Howe, S.S., 2002, Application of classification-tree methods to identify nitrate sources in ground water: Journal of Environmental Quality, v. 31, no. 5 , p. $1538-1549$.

Spruill, T.B., Tesoriero, A.J., Mew, H.E., Jr., Farrell, K.M., Harden, S.L., Colosimo, A.G., and Kramer, S.R., 2005, Geochemistry and characteristics of nitrogen transport at a confined animal feeding operation in a Coastal Plain agricultural watershed, and implications for nutrient loading in the Neuse River basin, North Carolina, 1999-2002: U.S. Geological Survey Scientific Investigations Report 2004-5283, 57 p.

State Climate Office of North Carolina, [n.d], 1971-2000 Climate Normals: State Climate Office of North Carolina, North Carolina State University, accessed December 2, 2014, at http://www.nc-climate.ncsu.edu/ cronos/normals.php?order=county. 
Stone, K.C., Hunt, P.G., Coffey, S.W., and Matheny, T.A., 1995, Water quality status of a USDA water quality demonstration project in the Eastern Coastal Plain: Journal of Soil and Water Conservation, v. 50, no. 5, p. 567-571.

Stone, K.C., Hunt, P.G., Humenik, F.J., and Johnson, M.H., 1998, Impact of swine waste application on ground and stream water quality in an eastern coastal plain watershed: Transactions of the American Society of Agricultural Engineers, v. 41, no. 6, p. 1665-1670.

Stow, C.A., Borsuk, M.E., and Stanley, D.W., 2001, Longterm changes in watershed nutrient inputs and riverine exports in the Neuse River, North Carolina: Water Research, v. 35, p. 1489-1499.

Tesoriero, A.J., Liebscher, H., and Cox, S.E., 2000, Mechanism and rate of denitrification in an agricultural watershed-Electron and mass balance along groundwater flow paths: Water Resources Research, v. 36, no. 6, p. 1545-1559.

Tesoriero, A.J., Spruill, T.B., Mew, H.E., Jr., Farrell, K.M., and Harden, S.L., 2005, Nitrogen transport and transformation in a coastal plain watershed: Influence of geomorphology on flow paths and residence times: Water Resources Research, v. 41, 15 p., accessed May 11, 2015, at http://dx.doi.org/10.1029/2003WR002953.

Tucker, M.R., 1999, Essential plant nutrients - Their presence in North Carolina soils and role in plant nutrition: North Carolina Department of Agriculture and Consumer Services, Agronomic Services, accessed May 6, 2014, at http://www.ncagr.gov/agronomi/pubs.htm.

U.S. Department of Agriculture, Natural Resources Conservation Service, 2009, Chapter 7 Hydrologic Soil Groups: National Engineering Handbook, Part 630 Hydrology, accessed December 2, 2013, at http:/www.nrcs.usda.gov/wps/portal/nres/detailfull/ national/water/?cid=stelprdb1043063.

U.S. Environmental Protection Agency, 1993, Method 365.1 Determination of phosphorus by semi-automated colorimetry, Revision 2.0, Methods for the determination of inorganic substances in environmental samples: U.S. Environmental Protection Agency EPA/600/R-93/100.

U.S. Environmental Protection Agency, 2010, National Water Quality Inventory Report to Congress, Electronic integrated reporting under Sections 305(b) and 303(d), 2010 reporting year, accessed June 17, 2013, at http://water.epa.gov/ lawsregs/guidance/cwa/305b/index.cfm.
U.S. Environmental Protection Agency, 2012, NPDES permit writers' manual for concentrated animal feeding operations, EPA 833-F-12-001, accessed April 10, 2015, at http:/water.epa.gov/polwaste/npdes/afo/ Implementation-Information.cfm.

U.S. Geological Survey, 2006, Collection, quality assurance, and presentation of precipitation data: U.S. Geological Survey, Office of Surface Water Technical Memorandum No. 2006.01 (revised December 2009), 29 p., accessed August 5, 2014, at http://water.usgs.gov/admin/memo/SW/ sw06.012_Revised_122009.pdf.

U.S. Geological Survey, variously dated, National field manual for the collection of water-quality data: U.S. Geological Survey Techniques of Water-Resources Investigations, book 9, chaps. A1-A9, available online at http://pubs.water.usgs.gov/twri9A.

Weaver, J.C., Terziotti, Silvia, Kolb, K.R., and Wagner, C.R., 2012, StreamStats in North Carolina - A water-resources Web application: U.S. Geological Survey Fact Sheet 2012-3137, 4 p.

Xue, D., Botte, J., De Baets, B., Accoe, F., Nestler, A., Taylor, P., Van Cleemput, O., Berglund, M., and Boeckx, P., 2009, Present limitations and future prospects of stable isotope methods for nitrate source identification in surface- and groundwater: Water Research, v. 43, p. 1159-1170.

Zublena, J.P., Baird, J.V., and Lilly, J.P., 1991, SoilFacts-Nutrient content of fertilizer and organic materials: North Carolina Cooperative Extension Service Publication AG-439-18, accessed May 5, 2014, at http://www.soil.ncsu.edu/publications/extension.html.

Zublena, J.P., Barker, J.C., and Carter, T.A., 1997b, SoilFacts-Poultry manure as a fertilizer source: North Carolina Cooperative Extension Service Publication AG-439-5, accessed May 5, 2014, at http://www.soil.ncsu.edu/publications/extension.html.

Zublena, J.P., Barker, J.C., Parker, J.W., and Stanislaw, C.M., 1997a, SoilFacts - Swine manure as a fertilizer source: North Carolina Cooperative Extension Service Publication AG-439-4, accessed May 5, 2014, at http://www.soil.ncsu.edu/publications/extension.html. 

Manuscript was approved on June 4, 2015

For further information about this publication contact:

Director
U.S. Geological Survey

South Atlantic Water Science Center

720 Gracern Road

Columbia, SC 29210

http://www.usgs.gov/water/southatlantic/

Prepared by the Raleigh Publishing Service Center 


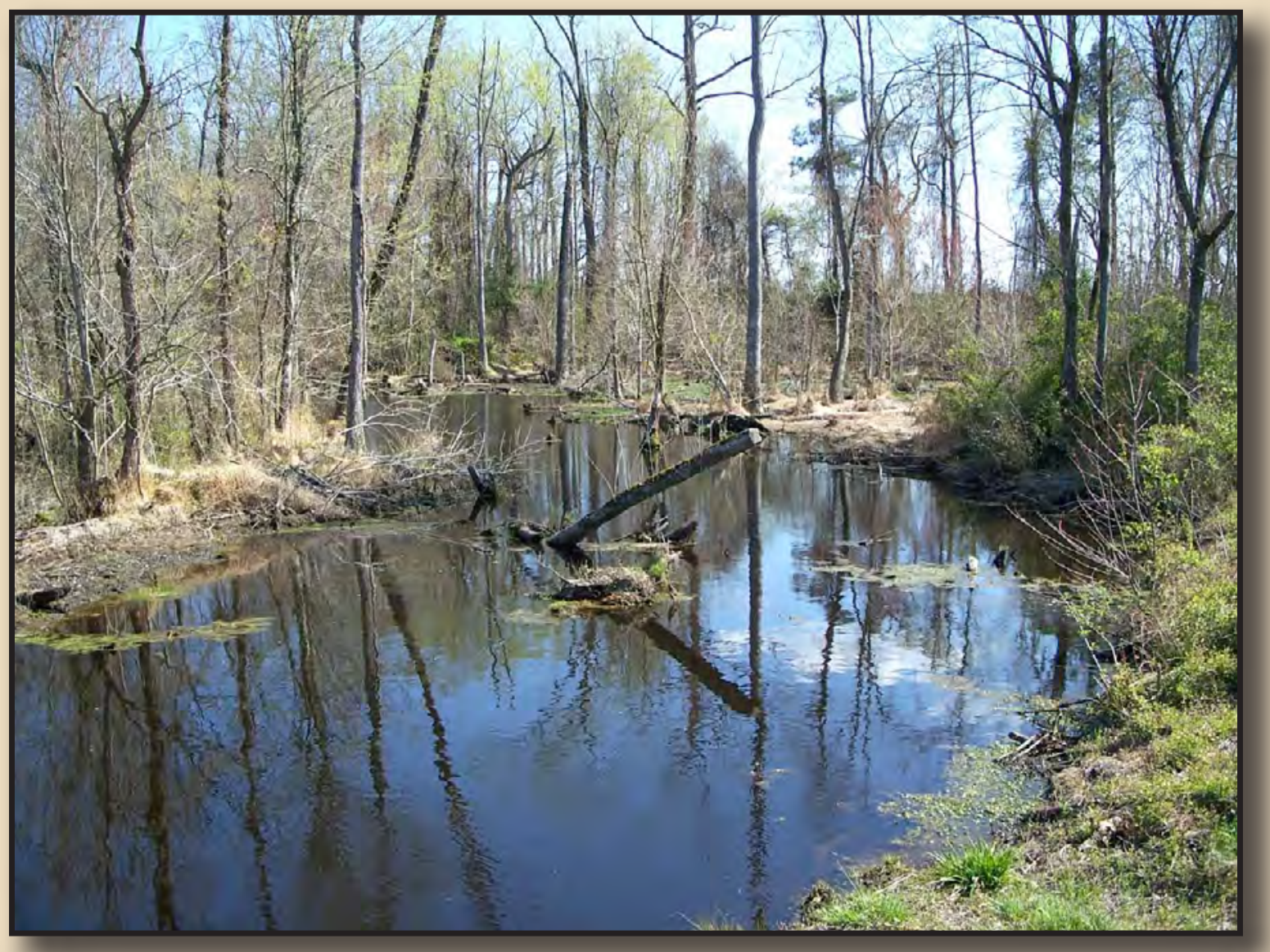

